Historic, Archive Document

Do not assume content reflects current scientific knowledge, policies, or practices. 
<smiles>C1CCCCC1</smiles> 


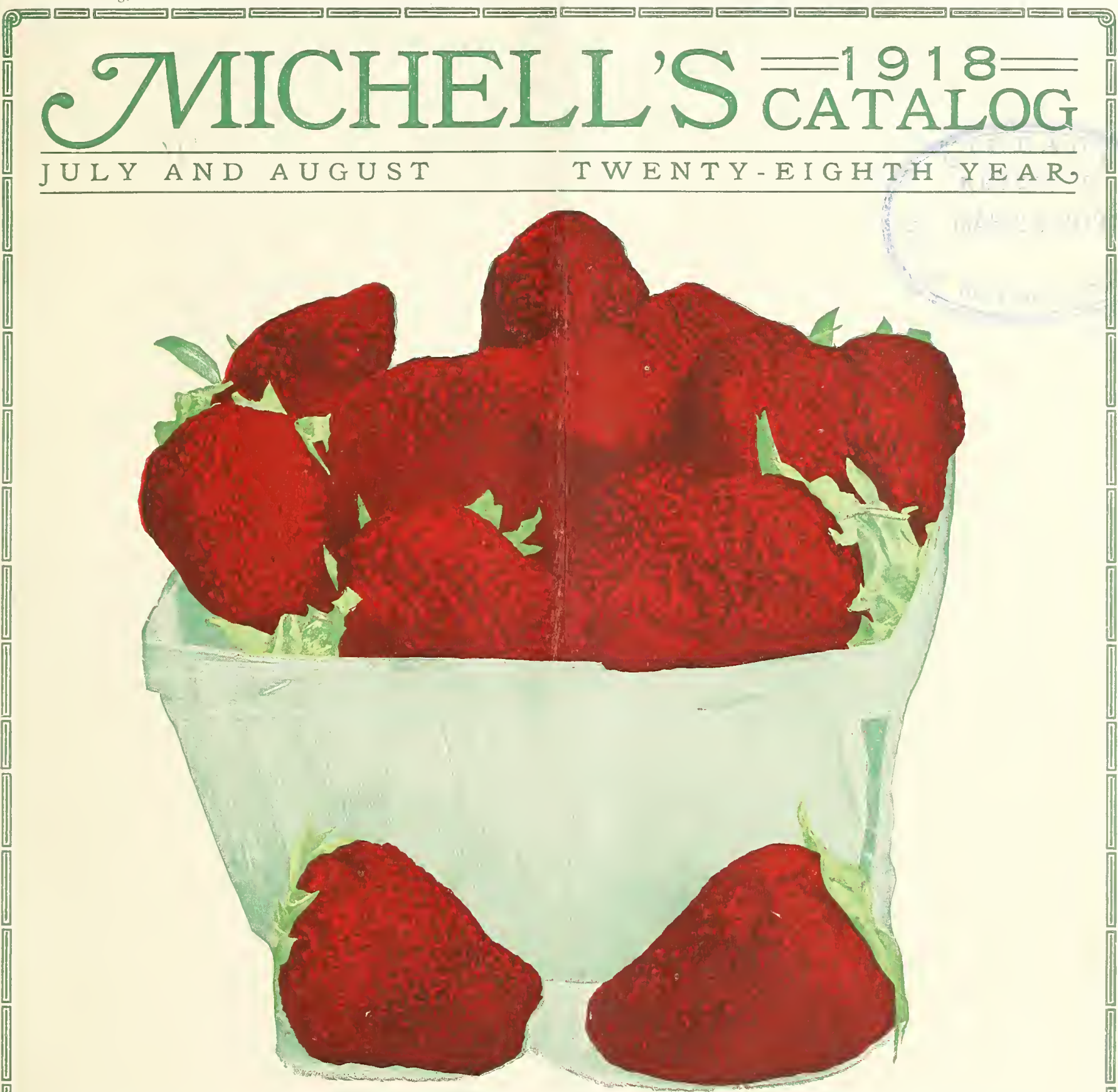

POT GROWN STRAWBERRY PLANTS are grown by us at our Nurseries at Andalusia, Pa., in large quantities and are usually ready for sending out after the first week in August.

Pot grown Strawberry Plants usually yield a full crop of fruit the first season after planting. Our list contains the leading varieties at the uniform price of $\$ 1.00$ per dozen; per $100 \$ 6.00 ; \$ 50.00$ per 1000 .

HENRY F. MICHELL CO. endeavor to send out only the very best quality of Seeds, Bulbs and Plants, but cannot Bulbs and Plants, but crops. If customers do not crept these acept these goods on the be returned to, they can ten days. TFLFPHONES

Bell-Lombard 4220 Keystone-Main 3600

\section{HENRY F. MICHELL CO.}

HENRY F. MICHELL, President FRED'K J. MICHELL, Vice-President

518 MARKET ST., - - $\quad$ PHILADELPHIA

Warehouses 19-21-23 Bank St., 509-11-13 Ludlow St.

Nurseries and Greenhouses: Andalusia, Pa.

U. S. Food Administration License G36797 
IMPORTANT-All prices are subject to any advances over present prevailing freight rates, customs duties or war tax, and all deliveries are subject to delay, restrictions, embargoes, crop shortages and all conditions beyond our control. All quotations are made and all orders are booked subject to above conditions.

HENRY F. MICHELI CO.

We Especially Invite Charge Accounts. A cliarge account is more convenient than to remit for each order at the time it is sent us; you pay no more for your goods by reason of this acconmodation. As to our responsibility we refer you to Dun's or Bradstreet's Mercantile Agency.

When sending your first charge order, refer, preferably, to someone with whom you have a charge account. This saves many a delay. When sending us your first orảer accompanied by remittance, we prefer bank cashier's check or money order, unless cash is sent; this frequently saves delays.

AT Goods ean be sent C. O. D., with the exception of perishable items, which includes plants and cold-storage bulbs. These cannot be sent C. O, D. unless a partial remittance accompanies the order.

\section{SHIPPING INSTRUCTIONS}

Always state clearly by what method you want goods for warded, otherwise we will ship according to our best judgment.

\section{INVITATION}

All customers and others interested in horticulture or agriculture are cordially invited to visit our plant establishment at Andalusia Station (N.Y. Division of P. R. R.) about 16 miles from Philadelphia. In the spring, summer and autumn we invariably have interesting displavs of hardv flowers, etc. This invitation applies to our city establishment as well, at 518 Market Street, Philadelphia.

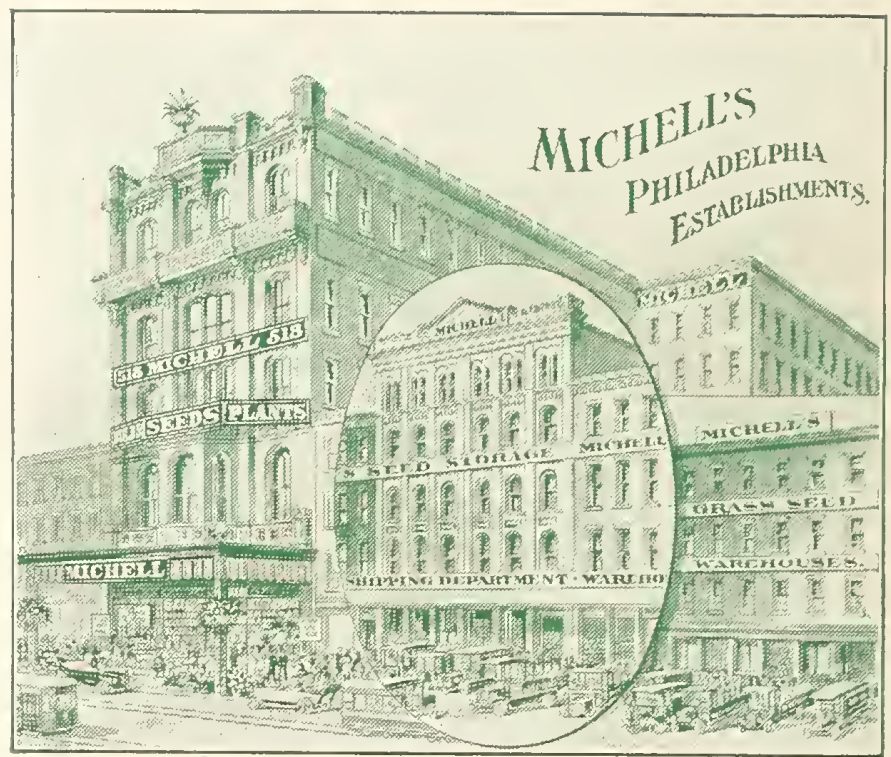

\section{DELIVERY SERVICE}

To points where baggage-master or package service is in operation we ship all orders, which can be packed in one parcel or piece, not exceeding 50 pounds in weight, free of transportation charges at prices quoted in this eatalogue. Fertilizers in more than 25-1b. lots, or bulky package, are not accepted by baggagemaster service. Our automobile delivery also covers many sections of Philadelphia.

\section{SHIPPING FACILITIES OF PHILADELPHIA}

Express-Wells-Fargo, Adams, American

Freight-Baltimore \& Ohio, Reading, Leligh Valley and Pennsvlvania.

Boat-Clyde Line, Merchants' \& Miners' Steamship Company.

The above transportation companies, with their connecting lines, enable us to ship quickly and economically all over the world.

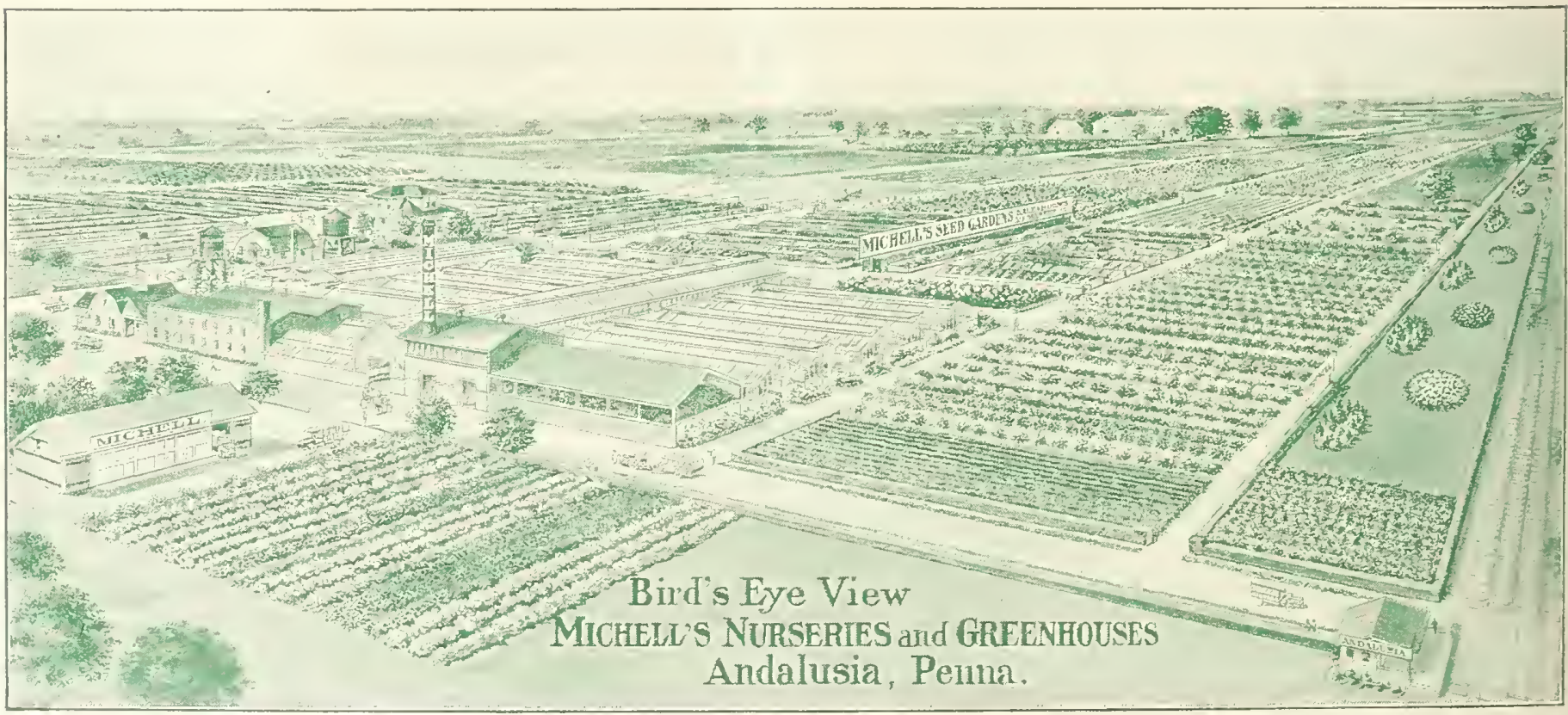




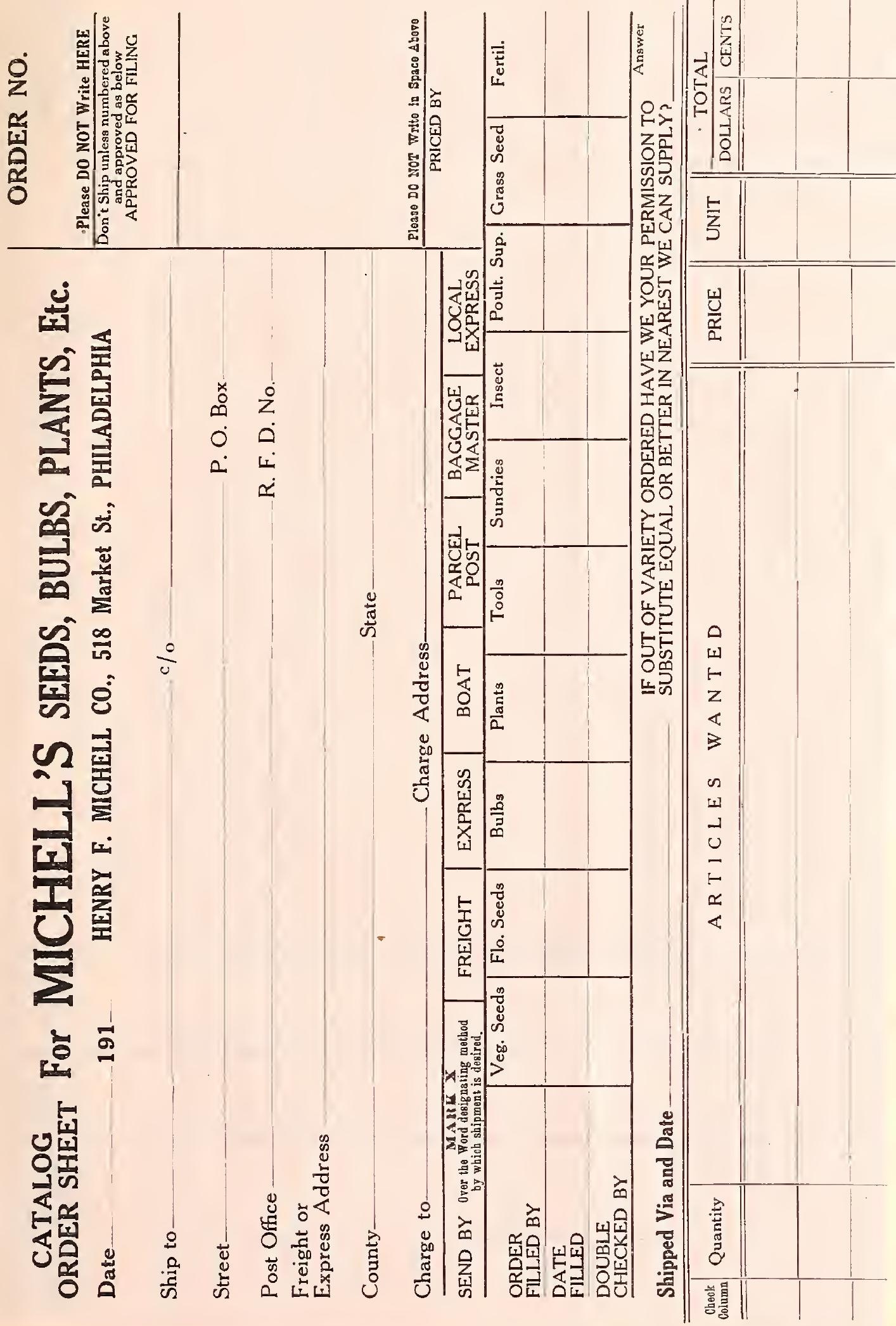






\section{SPECIAL}

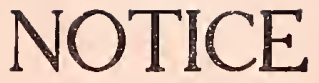

$\mathrm{N}$ account of unusual prevailing conditions, all prices are subject to market changes without notice, although we will use every effort to protect our customers against unnecessary advances in prices.

\section{HENRY F. MICHELL CO. \\ 518 Market Street, Phila.}

E. FORM 18, MICHELL PRESS 63.000 5.18 1A 
INDEX TO CONTENTS OF MICHELL'S 1918 SUMMER CATALOGUE

BULBS, ROOTS, ETC. PAGE Allium $\ldots \ldots \ldots \ldots \ldots \ldots$........ 10 Callas.......$\ldots \ldots \ldots$. 10 Freesias $\ldots . \ldots \ldots \ldots \ldots$...... I0 Hyacinths (Roman)...... Io Lilies $\ldots . . . . . . . . . .$. . II Lily of the Valley........ II Narcissus $\ldots . . . . . . . .$. . II Ornithogalum Oxalis

\section{SEEDS}

Alfalfa ............... 21 Clover ................ 2I Farm Seeds .......... 21 Flower Seeds .......12 to 17 Grass Seeds ............ 20 Mushroom Spawn ...... I9 Timothy ............. 2I Vegetable Seeds ....... 8 , 19 Wheat.......$\ldots \ldots$. 2I

\section{PLANTS, E'TC.}

Achillea

Actinidia

Adenophora

A egopodium

Aeth eopappus

Akebia

Alyssum

Ampelopsis

Anemone

Aquilegia

Arabis

Aristolochia

Artemisia

Asclepia

Astilbe

Baptisia

............

Brussels Sprouts ...........

Cabbage Plants

Calimeris

Callirhoe

Caryopteris

Catananche

Cedronella

..........

Celery Plants ...............

Cimicifuga ..............

Clematis

Dianthus

Echinops

Edelweiss

Erigeron

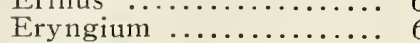

Eupatorium .............

Euonymus ............. 9

Galega ............... 6

Geum ................ 6

Gillenia $\ldots \ldots \ldots \ldots \ldots \ldots$

Gypsophila $\ldots \ldots \ldots \ldots \ldots 6$

Helenium

Helianthus

$\ldots \ldots \ldots \ldots$

Hemerocallis $\ldots \ldots \ldots \ldots \ldots$.

Hesperis

\section{PLANTS, ETC.}

Heuchera $\ldots \ldots \ldots \ldots \ldots .7$

Hieracium ............ 7

Honeysuckle ............

Iberis $. . \ldots \ldots \ldots \ldots \ldots \ldots, 7$

Inula

Lathyrus ...............

Lobelia

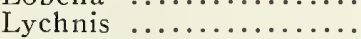

Lysimachia

Lythrum

Monarda

Oenothera

Orobus

Pachysandra

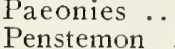

Physalis

Physostegia

Platycodon

Polemonium

Polyanthus

Polygonum

Primula ................. 7

Pyrethrum ..............

Roses $\ldots \ldots \ldots \ldots \ldots \ldots$....... 9

Rudbeckia

Saponaria

Schizophragma ...........

Sedum ............... 9

Senecio ............... 9

Solidago .............. 9

Spiraea …............

Statice $. . . \ldots \ldots \ldots \ldots . . .6$

Stokesia ............... 9

Strawberry Plants .....2, 3

Vegetable Plants ....... 4

Veronica ............. 9

Wistaria

\section{MISCELLANEOUS}

Animal Bone Potash, 3 rd cover

Ant Exterminator ...... 28 Antipest ..............28 Aphine $\ldots \ldots \ldots \ldots \ldots \ldots \ldots .28$ Aphis Punk .............. 28 Aprons ................ 23 Arsenate of Lead.......... 28 Ashes (Wood).....3rd cover Asparagus Fertilizer,

Bellows ......... 3rd cover Black Leaf ................ 28 Blood (Dried).....3rd cover Blood (Flour).....3rd cover Bon Arbor ........3rd cover Bone .............3rd cover

Bone Meal .......3rd cover Bordeaux Arsenate .....2 28 Bordeaux Mixture ........ 28 Border Shears ......... 24 Boro-Wax ............. 28

Bug Death $\ldots \ldots \ldots \ldots \ldots \ldots .28$

Carbolineum ........... 28 Chrysanthemum Manure,

Cider Mills .............. 23

Clay's Fertilizer...3rd cover

Copperas ........3rd cover

Copper Solution ...3rd cover

\section{MISCELLANEOUS}

Cotton Seed Meal.3rd cover Cow Manure ......3rd cover Cut Worm Destroyer.... 28 Cyanegg .............. 28

Dalmatian Powder ...... 28 Dissolved Bone....3rd cover Dowels ...............26 Dusters ..............25

Fern Pans .............27

Fibre Saucers .......... 27

Fibre Vases ............ 27

Fish Guano.......3rd cover

Fish Oil Soap.......... 28

Flower Pots ...............27

Fruit Pickers ..........23

Fungine .............. 28

Getz There Soap........ 28

Glass Cutters ..............23

Glazing Points ........... 23

Grape Bags .............. 24

Grape Dust ..............28

Greenhouse White .....23

Guano ...........3rd cover

Hedge Shears .......... 24

Hellebore ............28

Herbicide...$\cdots 4^{\text {th }}$ cover

Horn Shavings.....3rd cover

Hose ................ 22

Hose Connections ....22, 23

Hose Couplings .........22

Hose Menders .......... 22

Hose Reducers ........... 22

Hose Reels ............ 22

Humus .........3rd cover

Hyacinth Stakes ........ 26

Hydrant Aattachments .. 23

Hydrometers ........... 28

I. X. L. Compound....... 28

Kainit .........3rd cover

Kerosene Emulsion ..... 28

Kil-o-Scale ............. 28

Labels .................24

Lawn Dressing....3rd cover

Lawn Mowers ..........24

Lawn Mower Oil.......... 24

Leaf Racks .............. 24

Lawn Sand ........3rd cover

Lawn Sprinklers ........ 22

Lemon Oil Insecticides... 28

Lime ............3rd cover

Lime Sulphur ........... 28

Lime Stone ........3rd cover

Manures .........3rd cover Mapes Fertilizers..3rd cover Mastica .................23 Mastica Machine ......... 23 Mowers ................24 Mulford's Culture.3rd cover Muriate of Potash.3rd cover

Nico Fume ............ 28 Nicotine ............. 28 Nikoteen ................ 28 Nitrate ........... cover Nozzle Holders ......... 22 Nozzles ................. 23

Paris Green ........... 28

Paris GreenShakers..... 25 Persian Powder ........ 28 Phosphate .......3rd cover Plant Food .......3rd cover

\section{MISCELLANEOUS}

Plant Stakes ........... 26

Plant Tubs .................. 27

Poles ................25

Potato Fertilizer..3rd cover

Pots .................27

Pot Labels ............ 24

Poudrette .........3rd cover

Protecting Cloth ....... 24

Pumps ................ 25

Putty $\quad \ldots \ldots \ldots \ldots \ldots \ldots .23$

Putty Distributor ...... 23

Pyrox ............... 28

Raffia $\ldots \ldots \ldots \ldots \ldots \ldots .26$

Raffiatape
Rat Corn $\ldots \ldots \ldots \ldots \ldots \ldots \ldots . .26$

Readeana ................ 28

Rose Bug Exterminator.. 28

Rubber Aprons ........ 23

Rubber Hose ............. 22

Salt (Agricultura1),

3rd cover

Scalecide .................. 28

Scale Destroyer .......... 28

Seed Pans ............. 27

Shading Cloth ............. 24

Sheep Manure ....3rd cover

Shoo-Fly ............. 28

Sieves ............... 24

Slug Shot .............28

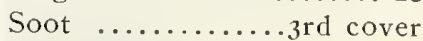

Sprayers ............. 25

Stakes ................26

Sulphate of Ammonia.... 28

Sulphate of Copper.....2 28

Sulphate of Potash.3rd cover

Sulpho Tobacco Soap.... 28

Sulphur .............. 28

Sulphur Candles ........ 28

Tankage .........3rd cover

Thompson's Special

Manure .......3rd cover

Thrip Juice .......... 28

Tobacco Dust .......... 28

Tobacco Stems ......... 28

Tree Labels ............24

Tree Tanglefoot ........ 28

Torches ............... 25

Tubs ..................27

Twines ...............26

Vapor Cones .......... 28

Vaporite .............28 28

Vases .................27

Vermine ..............28

Water Barrel Trucks.... 24

Water Cans ............23

Weed Killers .....4th cover Wheat Fertilizers. 3rd cover Wheelbarrows ......... 24 Wine Presses .......... 23 Wire ................26 26 Wire Stakes ............ 26 Wood Ashes......3rd cover Worm Destroyer ....... 28 Worm Eradicator ...... 28 
EXTRA SELECTED STOCK - Strong and Well Rooted. Will Yield a Full Crop of Berries Next Season. Ready About August 15th.

The time of shipment is from August 15 th to October Ist. The advantages in planting pot-grown strawberry plants are realized by a full crop of berries the following year. Our plants are carefully grown in clay pots and prior to shipment are transferred with the original ball of earth at their roots to substantial paper pots in which they are forwarded, thus insuring the buyer getting them in first-class order and reducing the transportation charges about 25 per cent.

\section{CULTURAL NOTE ON STRAWBERRIES}

Strawberries delight in good rich soil that has had plenty of manure added to it. The plants should be set 12 to 15 inches apart in rows 2 feet apart. A row too feet long requires approximately 75 to 100 plants or about 14,500 per acre. If the weather is dry, when planting, water well at the time and for a few days thereafter, if it is possible. Press the soil well around the ball, when planting, and keep the soil well cultivated, cutting off all runners that may form. At the approach of permanent winter it pays to cover the entire bed to a depth of 2 inches with clean straw or salt hay. This protects the plants during severe weather. Do not use leaves, as they hold the moisture and cause damage to the plants in winter. At the approach of spring, rake the covering from the plants proper and leave it between the rows; thus will serve as a mulch during the summer, protect against drought, and also keeps the fruit more free from sand, at the same time to a large measure controls the growth of weeds.

\section{EARLY VARIETIES}

Early Jersey Giant (Perfect). Pre-eminently the finest of the early varieties. It is brilliant scarlet-crimson in color, and exceptionally firm, by far the firmest of all early sorts. Berries very large, conical with pointed tip; has delightful aroma and rich, mild strawberry flavor. A very heavy yielder.

Early Ozark (Perfect). Among the very first to ripen and the berries are of fairly good size, bright, crimson color, slightly conical, quite firm and of excellent quality. A strong grower and a heavy yielder.

Senator Dunlap (Perfect. Early). This grand Strawberry will please the most critical person. One of the first to yield and continues well into the height of the season. It cannot be recommended too highly.

\section{MID-SEASON VARIETIES}

Big Joe (Perfect). The merits of this splendid variety are great vigor of plant, splendid root system, exceptional productiveness, large size of fruit, excellent flavor, and length of bearing season. The berries are perfect beauties, of very uniform conical shape, rich and red in color. In size the berries are not surpassed by those of any other variety grown, while the flavor is superior to that of most large fruited sorts. The plants root very deep, the roots going Io to 12 inches in the ground, that they are but little influenced by droughts.

Brandywine (Perfect). The finest of all mid-season sorts; it has not a single defect. The plants of extra strong constitution and growth, doing well everywhere. Fruit extra large, heart-shaped; color, bright, rich red.

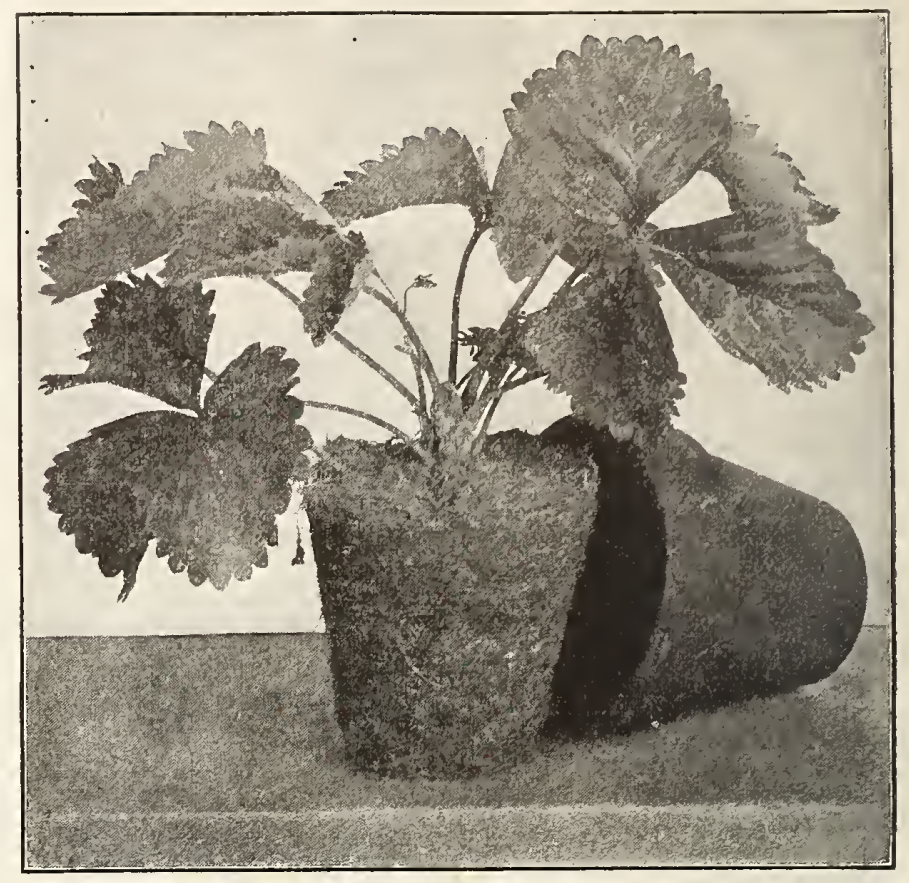

A husky developed specimen like this can't fail but give you satisfaction

\section{MID-SEASON VARIETIES (Continued)}

Gilen Mary (Perfect. Midseason). One of the best of the older varieties, as it still keeps its place among the prominent strawberries. The fruit is very large but rather irregular, somewhat like Sharpless. It is a great drought resister, ripening a full crop of luscious berries in the driest weather.

Heritage (Perfect). This is truly a giant strawberry, it being almost impossible to put a whole berry at a time in one's mouth. It is rather irregularly shaped but of a beautiful crimson color. The plants and foliage are entirely distinct which makes it stand out above all other sorts.

Nick Ohmer (Perfect). A superb variety for the home table, as it is a good grower, free from rust and bears heavy crops of large, dark, glossy red berries, highly colored all the way through, and of superior flavor.

Price of Pot=grown Strawberries on this page, $\$ 1.00$ per doz.; per 100, $\$ 6.00$; per 1000, $\$ 50.00$.

Success (Perfect). This wonderful berry is all that its name implies; it is a success from start to finish. Very vigorous grower; large fruit of high color and firmness, regular shape and a wonder in productiveness. Begins to ripen early and continues several weeks, retaining its large size all season.

NOTE-About October ist we can furnish layer plants of any of the above varieties at $25 \mathrm{c}$. per doz.; 100, \$1.50; $\$ 10.00$ per I000. If wanted by Parcel Post add IOc. per doz. or $20 c$. per Ioo for postage. Larger quantities travel best by express. 


\section{MICHELL'S POT-GROWN STRAWBERRY PLANTS}

\section{LATE SEASON VARIETIES}

\section{See Special Gultural}

Note on Page 2

Gandy (Perfect. Late). This variety is known to most every berry grower as one of the best late sorts. It is very solid and large, and of a beautiful crimson color; especially good for family garden planting.

Late Jersey Giant. (Perfect.) A large and very late variety and the most beautiful strawberry ever seen. It is a sport of the Gandy, but is superior to that grand old variety, the berries being larger, superior in quality, more brilliant in color, beautiful and produced in far greater number. The berries are heart-shaped and exceptionally uniform in shape and size; surface smooth and glossy; quality mild, rich and sweet. They are held from the earth on remarkably large, strong fruit stalks.

Stevens' Late Champion (Perfect). "Very large, fine flavored, bright color, good shipper, heavy yielder, good fruit stem." This berry has averaged 7,556 quarts per acre, neting $\$ 666.96$ per acre. It has been tested on all kinds of soils and will grow successfully where any strawberry will grow. It will stand a drought better than any other berry ever grown in this section. It has never shown any sign of rust.

Wm. Belt (Perfect). A grand sort. This variety was introduced some ten years ago, and at that time was lauded very highly and many plants were sold. The superb quality, the equal of which has not yet been attained in any other medium late variety, makes it very popular for the home garden and local market.

Price of Pot=grown Late Season Varieties Strawberries. $\$ 1.00$ per doz.; per I00, $\$ 6.00 ; \$ 50.00$ per I000.

NOTE-About October Ist we can furnish layer plants of any of the above varieties (except as noted) at $35 \mathrm{c}$. per doz.; per 100, \$I.50; $\$ 10.00$ per I000. If wanted by Parcels Post add Ioc. per doz. or 20c. per Ioo for postage.

\section{MICHELL'S SPECIAL GRADE BONE MEAL}

An excellent fertilizer to use when planting strawberries; about a teaspoonful to a plant. 25 lbs., \$I.25; $\$ 2.00$ per 50 lbs.; 100 lbs., $\$ 3.50 ; \$ 6.75$ per 2001 bs.

BOOKS ON THE CULTURE OF THE STRA WBERRY AND OTHER SUBJECTS (Mailed Postpaid)

Strawberry Culture (Fuller) ...............\$0.25

Berry Book (Biggle's) ...................... .50

Fruit Culturist (Thomas) $\ldots \ldots \ldots \ldots \ldots \ldots \ldots \ldots \ldots \ldots . .25$

Small Fruit Culturist (Fuller)................ 1.00

Principles of Fruit Growing (Bailey) ............. I.50

Fruit Garden (Barry's)...................... I.50

Mushroom Culture (Robinson)................ .50

Mushrooms, How to Grow (Falconer)............ 1.00

The Small Country Place (Maynard)............ I.50

For complete list of books see our General Catalogue.

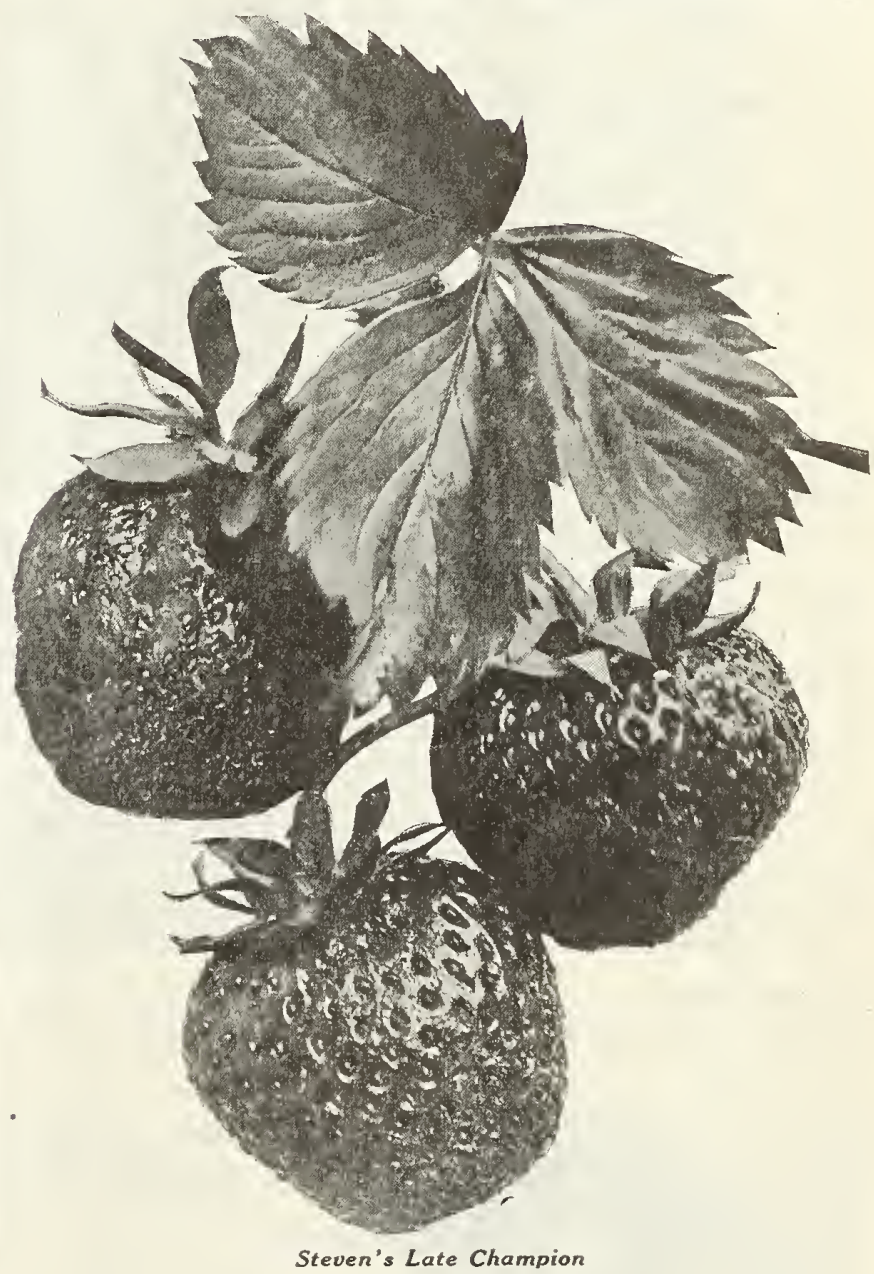

\section{MICHELL'S AUTUMN FRUITING OR EVERBEARING STRAWBERRY PLANTS (Pot Grown)}

This type, while producing its main crop of berries with the general sorts, continues uninterruptedly to mature its fruit, until checked by hard frosts; it has actually been known to bear strawberries until Christmas, when the weather is open and mild. In order to get the greatest crop of berries late, the blossoms should be kept cut off until August Ist, so as to conserve the energies of the plants for the fall crop. The plants must not be allowed to suffer for water in the fruiting season and a mulch of well rotted cow manure will be found of great advantage.

Progressive. The largest in size and of extreme producing qualities. The plant is of medium size and very resistant to heat. Both blossoms and fruit are well protected by the strong healthy foliage. The fruit is rich and sweet, a deep red inside and out, of good medium size and very firm. Pot grown plants, \$I.00 per doz.; per I00, \$6.00; per I000, $\$ 50.00$. Layer plants, ready about October Ist, 40c. per doz.; per I00, $\$ 2.50 ; \$ 22.50$ per I000. 


\section{Extra Strong Celery Plants}

(READY ABOUT JULY 10)

These plants are grown from our own seed at our Nurseries at Andalusia, Pa. We have immense quantities and can fill orders for any number.

A WORD ON CELERY CULTURE.-Celery delights in a good, rich, moist soil. Locations where the soil may become dry should be avoided. Nothing is more beneficial or so little work as the watering of celery during periods of drought. After it has been transplanted and made some growth, the plants should be set in permanent rows 6 to 8 inches apart in the row. Many private gardeners prefer to use the two-row system of trenches; it will be found very advantageous to work. If the idea of the market gardener is carried out, the celery is planted in single rows about 2 feet apart, 6 or 8 inches apart in the row. By the former method the celery is usually banked up to blanch until almost entirely covered with soil; the top is then covered with leaves or other litter as winter approaches. In the single-row system the celery is banked up gradually to blanch, and after this process is over, at the approach of winter it is dug up and laid in shallow trenches after being cleaned. Storing for winter is done by covering it with waterproof celery paper and topping off with soil or leaves. The celery may thus be gotten out for market during the severest weather. Good cultivation is highly necessary during the growing period.

French Golden Self=Blanching. An early sort. The heart is a rich golden-yellow, with light yellowish-green outer leaves. $75 \mathrm{c}$. per $100 ; 500$ for $\$ 3.00 ; \$ 5.50$ per 1000 .

Giant Pascal. One of the largest stalked kinds. It is in its prime for use during February and March, and can be used well up into spring.

White Plume. The White Plume is unsurpassed for fall and early winter use, requiring very little earthing to blanch

Winter Queen. This variety grows a very thick, solid and heavy stalk, and has a large heart. It it a close, compact grower, and when blanched is a creamy-white color.

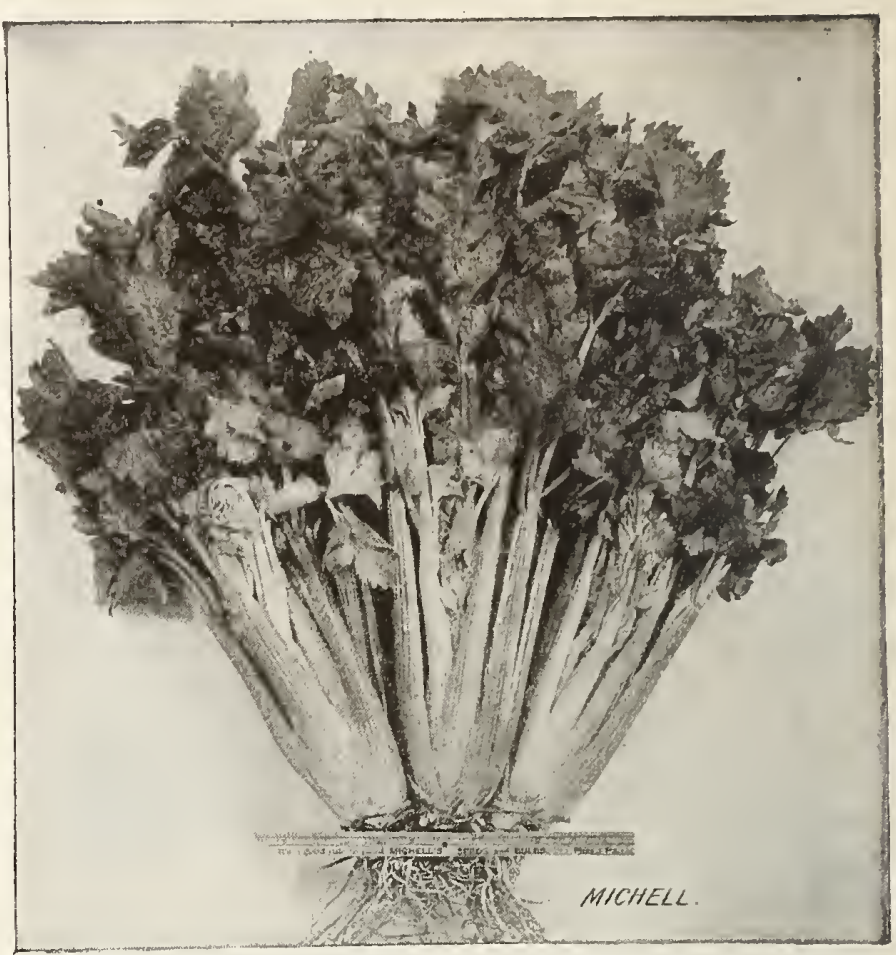

Michell's Golden Self-Blanching Celery

Prices: (Except where noted), 60c. per I00; 500 for $\$ 2.75$; $\$ 5.00$ per 1000

We cannot supply less than 50 celery plants of any one variety

If wanted by Parcel Post add I5c. per Ioo for postage.

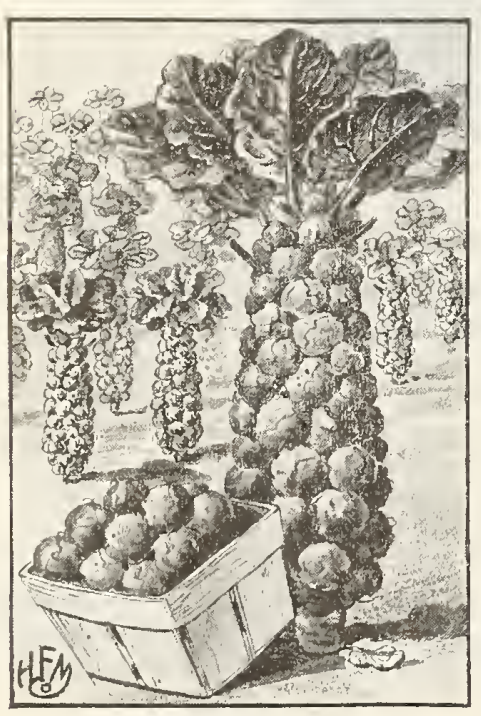

BRUSSELS SPROUTS

\section{PLANTS}

(Ready from July Ist to August I5th)

Matchless Improved. The plant's should be well cultivated and kept free from insects. When heads begin to crowd, the lower leaves should be broken from the stem of the plant to give them plenty of room. 25 for 20c.; 60c. per I00; per I000, $\$ 5.00$

If wanted by Parcel Post add Ioc. per Ioo for postage.

Brussels Sprouts

\section{CABBAGE PLANTS}

Late Flat Dutch. A short stemmed, large, flat-head variety; very solid; keeps the entire winter when buried in cellars

Perfection Drumhead Savoy. A very curly, dark-green sort; well-flavored.

Red Dutch Drumhead. This cabbage is very sweet and should be used more largely. It is an excellent winter keeper.

\section{CABBAGE PLANTS (Continued)}

Danish Ballhead. Unequalled for keeping qualities, massiveness and weight of heads.

Price of any of the above cabbage plants 25 for 20c.; 50c. per I00; per I000, $\$ 4.00$

We cannot supply less than 25 cabbage plants of a variety. If wanted by Parcel Post add ioc. per Ioo for postage.

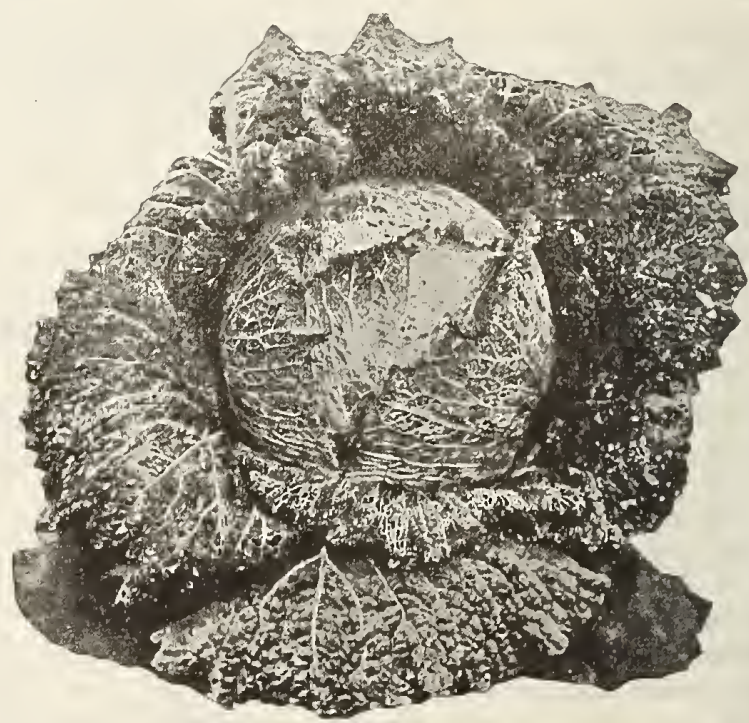

Perfection Drumhead Savoy Cabbage 


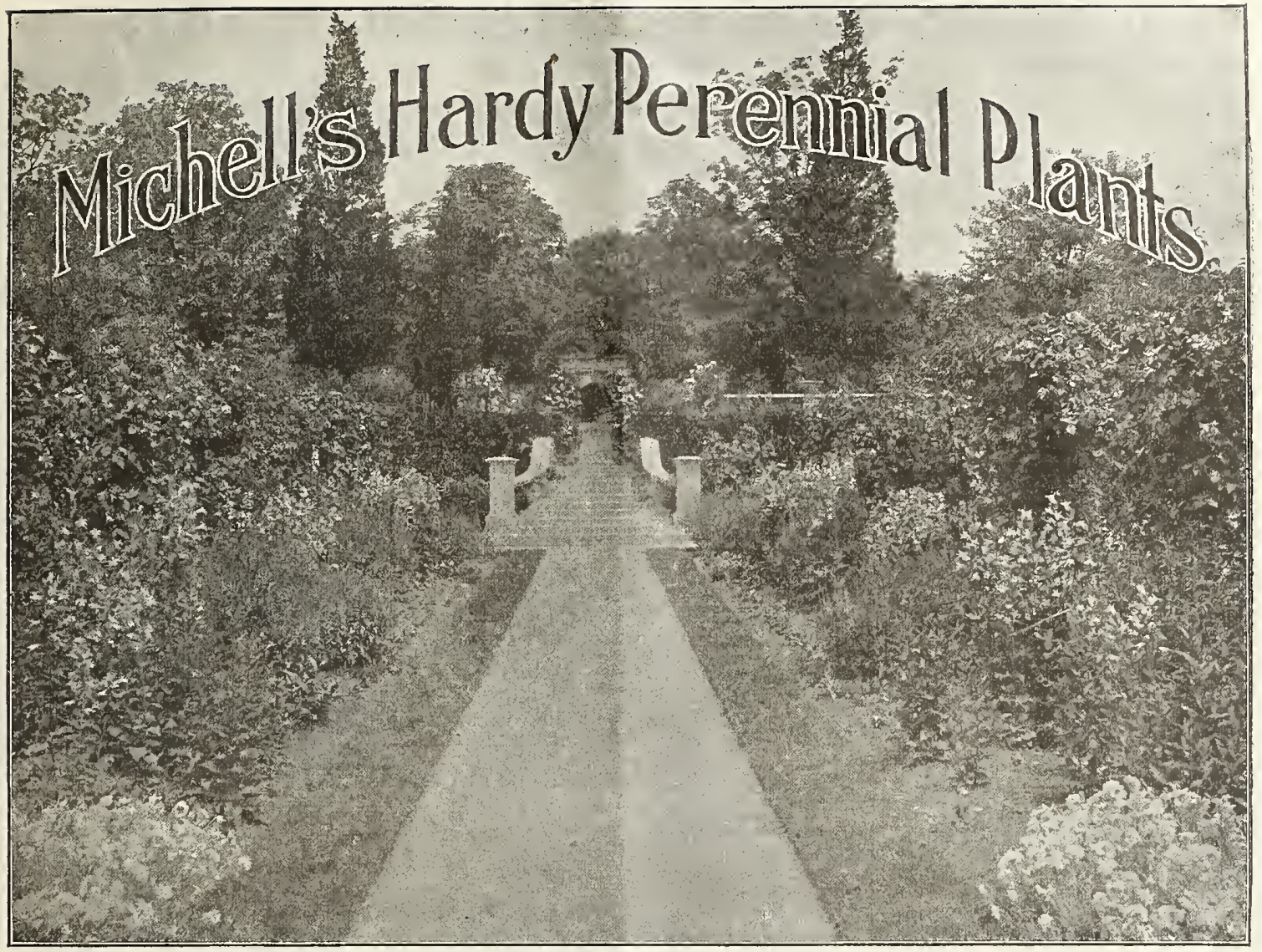

Results like this can be obtalned by planting Michell's Hardy Perenulals.

Our stock of Hardy Perennials is principally established in pots, which enables it to be shipped and transplanted at any season. All varieties mentioned in this list are ready for delivery now. Summer and Autumn planting frequently means a year's difference in results obtained the following spring.

\section{ACHILLEA (sneezewort)}

A graceful plant with finely cut foliage. Flowers are fine for cutting; flowering the entire summer.

Bonle de Neige (Ball of snow), Pure white; $21 / 2$ feet high.

Eupatorium. Brilliant yellow : 4 to 5 feet. Millefolium Cerise Queen. Rich amaranth 18 inches high; red.

Ptarmica Plena, The Pearl. Flowers the entire summer on strong. erect stems 2 feet high; of the purest white.

Ptarmica Grandiflora Fl. Pl. An improvement of the Ptarmica Plena ; flowers much larger. 25c. each: doz. 250

Price of any of the above (except as noted), 20c. each; doz., $\$ 2.00 ; \$ 15.00$ per 100.

\section{ADENOPHORA}

Potanini. Handsome bell-shaped blue flowers; borne on branching spikes. 20c. each ; doz., $\$ 2.00 ; \$ 15.00$ per 100 .

\section{AEGOPODIUM (Bishop's weed)}

Podagraria Variegata. Green and yellow variegated foliage: 1 foot high. 20c. each ; doz., $\$ 2.00 ; \$ 12.00$ per 100 .

\section{AETHEOPAPPUS (New)}

Pulcherrimus. The flowers, resembling Giant Cornflowers, are of a dazzling pink. Splendid for cutting; July; $21 / 2$ feet high. $30 \mathrm{c}$ each; doz., \$3.00.

\section{ALYSSUM}

\section{(Gold Dust or Basket of Gold)}

Splendid edging plants. Ideal for rockery ; 1 foot high.

Rostratum. Bright golden yellow.

Saxatile Compactum. Golden yellow.

Price of Alyssums, 20c. each; doz., $\$ 2.00$; $\$ 12.00$ per 100

\section{ACONITUM}

(Monkshood or HeImet Flower)

Bushy plants, blooming in clusters of beautiful helmet-shaped flowers from late summer till frost. Well adapted for shade.

Autumnale. Deep purplish blue; flowering in September.

Fischeri. Grows 18 inches high, yielding pale blue flowers.

Lycoctonum. A free-flowering pale vellow variety, blooming during June and July.

Napellus. Large flowers, dark blue; August and September ; 3 to 4 feet.

Napellus Bicolor. Dark blue and white flowers: 3 to 4 feet.

Sparlk's Variety. The darkest blue of all 5 to 6 feet high.

IVilsoni. A variety from Northern China, growing 6 feet high; pale violet blue; fowers in September.

Price of Aconitums, 30c. each ; doz., $\$ 3.00$; $\$ 18.00$ per 100 .

\section{ANEMONE JAPONICA (Windilower)}

As a last greeting of autumn these gay flowers appear in wondrous brilliancy and produce a wealth of bloom

Alba. Large pure white; 3 to 4 feet tall.

Hupehensis. A new introduction from China. Grows about 12 inches high, and are covered from August until frost with masses of pale pink flowers. 25c. each ; doz., s. 00

Pennsylvanica. Our native Windflower. White flower with a tinge of red on the under side; 18 inches high

Rubra. Rich rosy red : 3 to 4 feet

Whirlwind. Large semi-double, pure white. Price of Anemones (except where noted), 20 c. each ; doz., $\$ 2.00 ; \$ 12.00$ per 100 .

\section{AOUILEGIA (Columbines)}

For spring flowers these are invaluable, producing their graceful spurred flowers on stems rising 2 feet over their elegant foliage, during May and June.

Canadensis. Bright red and yellow.

Erskine Park Ilybrida (Mixed Colors). A grand mixture of finest varieties.

Flabellata Nana Alba. Dwarf; pure white. Rose Qneen. A pleasing shade of delicate pink, long spurred flowers,

Price of above Aquilegias, 20c. each ; doz., $\$ 2.00 ; \$ 12.00$ per 100 .

\section{ARABIS (Rock Cress}

Dwarf bushJ plants 6 inches high: ideal Dreckeries and borders.

Alpina. Single snowy-white flowers. 20c each ; doz., $\$ 2.00 ; \$ 12.00$ per 100 .

Alpina Fl. Pl. Double white, very showy. 25ceach: doz, \$2.50:\$17.50 per 100

Alpina Rosea (New). The plants are liter ally covered with rose-pink flowers in April and May. 35c. each; doz., $\$ 3.50$.

\section{ARTEMISIA}

Abrotanum (Old Mlan). Dark green foliage, which has a pleasant aromatic odor.

Pedemontana. Very ornamental variety, with finely cut silvery foliage; 2 feet high.

Stellariana (old Woman). Silvery foliage;

extensively used for carpet bedding.

Price of Artemisias, 25c. each; doz., $\$ 2.00$ 12.00 per 100

\section{ASCLEPIAS (Butterfily Weed)}

Incarnata (Swamp Milkweed). Very showy border plant; $21 / 2$ feet high; rose pink flowers in July and August.

Tuberosa. A showy plant, 2 feet high, with

large heads or clusters of orange flowers

blooming in July and August.

Price of Asclepias, 20c. each; doz., $\$ 2.00$ 12.00 per 100 
ASTILBE ARENDSI

The plants of this Spixaea type are of vigorous growth; $2 \frac{1 / 2}{2}$ to 3 feet high, producing branched feathered heads of flowers in June and July.

Ceres. Brilliant lilac rose.

Juno, Vigorous grower, with plumes of a deep violet color.

Salmon Queen. Graceful plumes of a beautiful salmon pink.

Venus. Plumes are of a brilliant purplish pink color"; charming new variety.

Vesta. Light lilac rose plumes.

Prices of the above Astilbes, 35c. each; doz., $\$ 3.50$

\section{ASTILBE}

They like a half shaded location, and plenty of moisture.

Davidii. The stems, which are 5 to 6 feet high, are crowned with feathery plumes of deep rose violet flowers; June-July. 25 c. each ; doz., $\$ 2.50$.

Grandis. The panicles of white flowers are frequently $2 \frac{1}{2}$ feet long; very attractive fine foliage; blooms July-August. 25c. each ; doz., \$2.50.

\section{BAPTISIA (False Indigo)}

Australis. A robust growing plant, suitable for the border or wild garden. The flowers are dark blue, borne on spikes, in June and July; 2 feet high.

Tinctoria. Bright yellow; 2 to 3 feet.

Price of Bâptisias, 25c. each ; doz., $\$ 2.00$;

$\$ 12.00$ per 100

\section{BOLTONIA (False Chamomile)}

Tall-growing, showy plants, with hardy aster-like flowers: September; 5 to 7 feet. Asteroides. Pure white ; 5 to 6 feet.

Latisquama. Pink, tinted lavender; 6 feet. Latisquama Nana. Pink, tinted lavender; 2 feet high

The above, 20c. each; doz., $\$ 2.00 ; \$ 12.00$ per 100 .

\section{CALIMERIS (Starwort)}

Incisa. Attractive border plant, growing from 1 to $1 \frac{1 / 2}{2}$ feet high. The daisylike flowers are of a delicate lavender shade, with a vellow centre; blooms from July to September. 25c. each; doz, $\$ 2.50$; $\$ 17.50$ per 100

\section{CALLIRHOE (Poppy Mallow)}

Involucrata. Large crimson flowers with white centre; blooms all summer. each ; doz., $\$ 2.00 ; \$ 12.00$ per 100 .

Lineariloba. Large Poppy-like flowers, crimson and white; 9 inches; June-September. 20c. each; doz., $\$ 2.00 ; \$ 12.00$ per 100.

\section{CAMPANULA (Bell Filower}

Glomerata (Cluster Bell Flower). Densely (c)ked stamens of violet-colored flowers: July and August; height, 20 inches.

Pyramidalis (Chimney Bell Flower). The tallest of all Bell flowers, growing from 5 to 7 feet in height, the massive flower stalks being dressed with the beautiful bells from August till October. Blue and White, each separate. 25c. each ; doz., $\$ 2.50 ; \$ 17.50$ per 100 .

Persicifolia (Peaeh Bell). Extremely hardy making a splendid show in June, July and August. The stately spikes are tall, often 3 feet high, and present a grand appearance. Blue and white; each separate.

Trachelium (Coventry Bells). Purple flow. ers : June and July : 3 feet high.

Latifolia Macrantha. Very handsome, large drooping bells of a fine satiny lilac and deep purplish shades; 3 feet

Rotundifolia (Blue Bells of Scotland). Light, graceful spikes of drooping deep blue flowers; 6 to 12 inches.

Price of any of the Campanulas (except where noted ), 20c. each; doz., $\$ 2.00 ; \$ 12.00$ per 100

\section{CARYOPTERIS}

Iaslacanthus (Blue Spiraea). A hardy ner easiest culture, flowcring in September and October. The flowers are light blue; 2 feet high. 20c. each; dor, $\$ 2.00 ; \$ 12.00$ per 100 .

\section{CEDRONELLA (Balm or Gilear}

Cana. Long spikes of purple, salvia-like flowcrs, with highly scented foliage; $21 \%$ feet high; July to September. 20c. each; doz., $\$ 2.00 ; \$ 12.00$ per 100 .

CATANANCHE (Cupid's Darts)

The flowers resemble somewhat the Cornflower.

Bicolor. Blue and white; 2 feet high.

Coerulea. Bright blue; 2 feet. The above 20c. each; doz., $\$ 2.00 ; \$ 12.00$ per 100.

\section{CIMICIFUGA (Snake Root)}

Dalnurica. Bold, erect, cylindical flower stems, over 4 feet high with a wealth of creamy white flowers in August and September. 25c. each; doz., $\$ 2.50 ; \$ 17.50$ per 100.

Racemosa. Tall growing plant, 4 to 6 feet high, well suited for borders or naturalizing at the edge of woods: flowers pure white; July and August. 25c. each ; doz., $\$ 2.50 ; \$ 17.50$ per 100

Simplex. One of the latest plants to flower in our collection, beginning to bloom in late September. The spikes, 2 to 3 feet long, are covered with beautiful white flowers; excellent for cuttting. 50c. each ; doz., $\$ 5.00$.

\section{DIANTHUS (Garden Plnks)}

Deltioides (Maiden Pink). A continuous flowering variety with pink flowers.

Deltioides Alba. White flowers.

Lactifolius Atrococcineus Fl, Pl. (Everblooming Hybrid Sweet William) A splendid variety with brilliant crim

Each of the above, 20c. each; doz., \$2.00

$\$ 12.00$ per 100

\section{ECHINOPS (Globe Th1stle)}

Handsome plants for the border or wild arden.

Ritro. A noble, effective variety for shrubberies and borders, producing handsome blue, globular flowers: $31 \%$ feet.

Rutlienicus. Interesting and showy, solid round heads of lovely blue flowers, on branching stems; 3 feet.

Splaerocephalus. Large, white flowers, fine for a background; plants growing 5 to 6 feet tall.

Price of any of the above Echinops, 25c. each; doz., $\$ 2.50 ; \$ 17.50$ per 100.

\section{EDELWEISS (Graphallnm)}

Leontopodiun Alpinum. This is the favorite Alpine plant of the Swiss Mountains. The plant is dwarf, about 4 inches high, with gray foliage, which lies close to the ground, is surmounted with stalks of gravish white,

fuzzy flowers of a trilobed appearance The flowers may be cut as an everlasting. and they will keep indefinitely. This is a splendid plant for a rock garden.

each; doz, $\$ 2.50$; $\$ 17.50$ per 100 .

\section{ERIGERON (Flea IBane)}

Grandiflor'us Elatior. Large, bluish lilac flowers with yellow disc: 18 inches: JuneJuly. 20c. each; doz., $\$ 2.00 ; \$ 12.00$ per 100.

Intermedium. Daisy-like light pink flowers all summer ; 2 feet. 25 c. each ; doz., $\$ 2.50$; $\$ 17.50$ per 100 .

\section{ERINUS}

Alpinus Carmineus. A charming Alpine plant; grows in the crevices of rocks or walks; producing dainty sprays of rosecolored flowers.

Alpinus Albus. White.

Price of above Erinus, 20c. each; doz. $\$ 2.00 ; \$ 12.00$ per 100

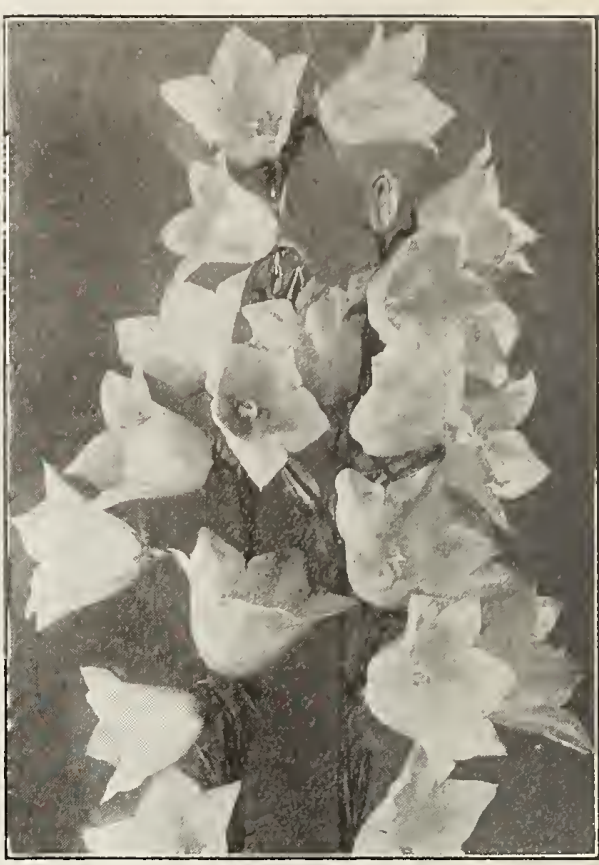

Campanula Pyramidalis

ERYNGIUM (Sea Holly)

Yaluable for shaded locations or wild garlen effects; July-September.

Amethystinum. Amethyst-blue.

Planum. Light blue.

Price of the above Eryngium, 25c each; doz, $\$ 2.50 ; \$ 17.50$ per 100

\section{EUPATORIUM}

Produces fuzz-like flowers: resembling Igeratum. Appearing from August till frost Ageratoides (White Snakeroot). Pure white 3 to 5 feet; August and September.

Coelestinum. Light blue, flowering in Auoust: 18 to 24 inches.

Purpureum Maculatum (Joe Pye Teed) Purple to flesh color; 4 to 6 feet.

The above, 20c. each; doz., $\$ 2.00 ; \$ 12.00$ per 100.

GALEGA (Gont's Rne)

Iartlandii. Large, handsome blue and white flowers and variegated foliage: $2 \mathrm{ft} .20 \mathrm{c}$ each; doz., $\$ 2.00 ; \$ 12.00$ per 100 .

\section{GEUM (Avens)}

Bright, showy flowers in the early summer and fall, growing about 18 inches high.

Coccinea. Brilliant rich scarlet. 25c. eaclı doz.. $\$ 2.50$.

Irs. Bradsliaw (New). Double, bright scarlet: 18 inches. 25c. each; doz, $\$ 2.50$.

Miniatun Perry's Variety. Rich orange colored; splendid new variety. 50c. each: doz., $\$ 5.00$

\section{GILLENIA (Bowman's Roo1)}

Trifoliata. A spiraea-like plant, with thin flowered stems, graceful foliage and rosy white blooms; 2 feet high; July-August. 25 c. each; doz., $\$ 2.50 ; \$ 17.50$ per 100 .

GYPSOPHILA (Baby's Breath)

These may be used as fresh cut flowers, also for a semi-everlasting effect. They keep perfectly for months without water ; AugustSeptember.

Paniculata. Feathery sprays of white flowers. 20c. each; doz., $\$ 2.00 ; \$ 12.00$ per 100

aniculata flore pleno. Double pure white flowers. Splendid for bouquets. 30c. each : doz., $\$ 3.00 ; \$ 20.00$ per 100 .

Repens. A useful plant for the rockery, with small white flowers; July-August. 25c each : doz., $\$ 2.50 ; \$ 17.50$ per 100 


\section{MICHELL'S HARDY PERENNIAL PLANTS}

\section{HELENIUM (Sneezetwort)}

These desirable perennials succeed in almost any soil in a sunny location.

Autumnale Rubrum. Bright red; 5 feet.

Autumnale Superbum. Massive spreading heads of deep golden yellow flowers; August-October; 5 feet.

Riverton Beauty. Rich lemon-yellow with dark purple cone; 4 feet; August.

Riverton Gem. O1d gold changing to red. Price of Heleniums, 25c. each; doz., $\$ 2.50 ; \$ 15.00$ per 100 .

\section{HELIOPSIS (Orange Sunflower)}

Excelsa. A tall variety with large double yellow flowers with 4 or 5 rows of florets with fringed tips. $35 \mathrm{c}$. each; doz., $\$ 3.50$.

HELIANTHUS (Hardy Sunfiower)

Very effective either in borders, among shrubbery or as clumps on the lawn, etc. Maximiliana. The latest of all; blooming profusely in October; the fine golden yellow flowers appear in long, graceful sprays; splendid for cutting; 5 to 7 feet.

Multiflorus fl. pl. Large, double golden yellow; July-August; 4 feet.

Orgyalis. Golden yellow; small flowered; long, narrow foliage; Sept.; $5 \mathrm{ft}$.

Rigidus Miss Mellish. Semi-double flowers; 4 to 5 inches across; very long petals of golden yellow; good for cutting.

Price of the above Helianthus, $20 \mathrm{c}$ each; doz., \$2.00; \$12.00 per I00.

HEMER OCALLIS (Yellow Day hily)

Aurantiaca Major. Large, orange flowers; one of the best sorts; June-July. 25 c. each; doz., $\$ 2.50 ; \$ 17.50$ per 100.

Dr. Regal. Rich apricot; $2 \mathrm{~T} / 2$ feet. $25 \mathrm{c}$. each; doz., \$2.50; \$17.50 per 100.

Dumortieri. Rich yellow flowers, bronze shaded on the back of petals; June. 25 c. each; doz., $\$ 2.50 ; \$ 15.00$ per 100.

Florham. A strong grower; 3 to $3^{\mathrm{T} / 2}$ feet high; large trumpet-shaped flowers; rich golden yellow with Indian yellow markings; June-July. 30c. each; doz. $\$ 3.00 ; \$ 20.00$ per 100 .

Kwanso Flore Pleno (Double). Coppery red; July; 3 feet high. 2oc. each; doz., $\$ 2.00 ; \$ 12.00$ per 100 .

Queen of May. Spikes are terminated with from I2 to I8 flowers of a rich Indian yellow color; May to July. 3oc. each; doz., \$3.00.

\section{HESPERIS (Rocket)}

Matronalis. Bushy plants; 3 to 4 feet high, with showy spikes of pink flowers during June and July.

Matronalis Alba. White.

Price of above Hesperis, 20c. each; doz., \$2.00; \$I2.00 per I00.

\section{HEUCHERA (Alnm Root)}

Sanguinea Alba. Creamy white; 2 feet. Sanguinea. Bright scarlet.

Price of Heuchera, except where noted, 25 c. each; doz., \$2.50; \$I 5.00 per 100.

HIERACIUM (Hawkweed)

Aurantiacum. Deep orange; 12 to I8 inches. 20c. each; doz., \$2.00; \$12.00 per 100.
IBERIS (Hardy Candyturt)

In spring and early summer they are completely covered with white flowers. Sempervirens. Pure white flowers.

Sempervirens Snowflake. An improved form.

Price of Iberis, 20c. each; doz., $\$ 2.00$; I2.00 per IOO.

\section{INULA (Flea Bant)}

Glandulosa Grandiflora. A very showy. plant with numerous bright golden flowers on long leafy stems; 2 feet; June-August.

Macrocephala. Splendid bright yellow.

Price of above Inulas, 25c. each; doz., $\$ 2.50 ; \$ 17.50$ per Ioo.

\section{LOBELIA}

Cardinalis (Cardinal Flower). Vivid crimson flowers on spikes from 2 to 4 feet high; July-August. 20c. each; doz., $\$ 2.00 ; \$ 12.00$ per 100 .

\section{LYCHNIS (Campion)}

Chalcedonica. Heads of brilliant orange scarlet; 2 feet high.

Chalcedonica Alba. White; 2 feet high

Haageana Hybrida. Brilliant shades o orange and scarlet; height, 12 inches. Vespertina Double White. Double white flowers. 25c. each; doz., $\$ 2.50$.

Viscaria (Ragged Robin, London Pride). Double red flowers; June.

Viscaria Splendens Plena. Double white. Price of any of the above Lychnis (except where noted), 20c. each; doz., $\$ 2.00$ \$12.00 per I00.

LYSIMACHIA

Clethroides. White; 3 feet high; JulySeptember.

Nummularia (Creeping Jenny or Moneywort). Excellent for planting under trees or shrubs.

Price of above Lysimachias, 20c. each; doz., \$2.00; \$12.00 per 100 .

\section{LYTHRUM (Loose Strife)}

Succeeds in most any locality. July until September.

Brightness. Bright pink; tall erect spikes.

Rose Queen. An improvement of the Roseum Superbum.

Price of Lythrum, 25c. each; doz., $\$ 2.50 ; \$ 15.00$ per IOO.

\section{MONARDA (Bergamot)}

Showy plants; 2 to 3 feet high; flowering during July and August.

Didyma Cambridge Scarlet (Oswego Tea). Brilliant scarlet. 20c. each; doz., $\$ 2.00 ; \$ 12.00$ per I00.

Didyma Salmonea. Salmon rose. 25c. each; doz., \$2.50; \$17.50 per 100.

OENOTHERA (Evening Primrose)

Flowers all season.

Eldorado. Double golden yellow.

Fraseri. Deep yellow; I8 inches high Speciosa. Pure white; 18 inches high.

Price of any of the Oenothera, 20c. each; doz., \$2.00; \$12.00 per I00.

\section{OROBUS (Bitter Vetch)}

Excellent for borders or rockeries, flowering in May and June.

Lathyroides. Pea-shaped blue flowers; I foot. 25c. each; doz., \$2.50; \$I5.00 per IOO.

\section{PACHYSANDRA}

An evergreen trailing plant, with thick, glossy foliage forming a dense mat, doing well either in the sun or shade.

Terminalis. Green; 6 to 8 inches high; small flower spikes of a grayish white, in May and June. 2oc. each; doz., $\$ 2.00 ; \$ 15.00$ per I00.

PENSTEMON (Benrdl Tongue)

Starts to flower in early summer and lasts until frost.

Barbata Torreyi. Brilliant scarlet.

Barbata Salmonea. Long panicles of salmon rose flowers. 35c. each; doz. $\$ 3.50$.

Digitalis. Purplish white flowers with dark purple throat.

Gloxiniodes "Sensation." Bears spikes of large gloxiniae-like flowers in a great variety of bright colors. Blooms until frost.

Ovatus. Bright blue, shaded bronzy purple.

Price of the above, except as noted, 20c. each; doz., \$2.00; \$12.00 per I00.

\section{PHYSALIS (Lantern, Plant}

Francheti. Ornamental variety of the Ground or Winter Cherry; 2 feet high. 20c. each; doz., $\$ 2.00 ; \$ 12.00$ per I00.

\section{PHYSOSTEGIA (False Dragon Head)}

Attractive perennials, blooming July and August; 3 to 4 feet high.

Virginica. Delicate soft pink.

Virginica Alba. Pure white.

Price of either of the above, 20c. each; doz., $\$ 2.00 ; \$ 12.00$ per I0O.

\section{PLATYCODON (Japanese Bell Flower)}

June until October; height, 2 to 3 feet Grandiflorum. Beautiful blue; very handsome.

Grandiflorum Album. Identical with the above, except the color, which is pure white.

Mariesi. Dwarf; compact; beautiful blue. Price of either of the above, 20c. each ; doz., $\$ 2.00 ; \$ 12.00$ per 100 .

POLEMONIUM (Jacob's Ladder)

Richardsoni. Sky blue with golden anthers; June-Sept.

Richardsoni Alba. A white form of the above; June-Sept.

Price of the above, 20c. each; doz., $\$ 2.00 ; \$ 12.00$ per 100 .

PRIMULA (Hardy Primrose)

Acaulis Alba Plena. Double white. 25c. each; doz., $\$ 2.50$.

Acaulis Lilac. Very early and prolific. 25c. each; doz., \$2.50.

Vulgaris (English Primrose). Canary yellow. 20c. each; doz., \$2.00; \$12.00 per 100.

Veris (English Cowslip). A mixture covering various shades of red and yellow. 20c. ea.; doz., \$1.50; \$10.00 per I00.

\section{PRIMULA POLYANTHUS}

New Hybrids Mixed. Comprises the finest varieties in crimson, yellow, golden laced, etc., in magnificent mixture. $20 \mathrm{c}$. each; doz., \$1.50; \$10.00 per 100. 


\section{MICHELL'S GORGEOUS DOUBLE PAEONIES (Roots)}

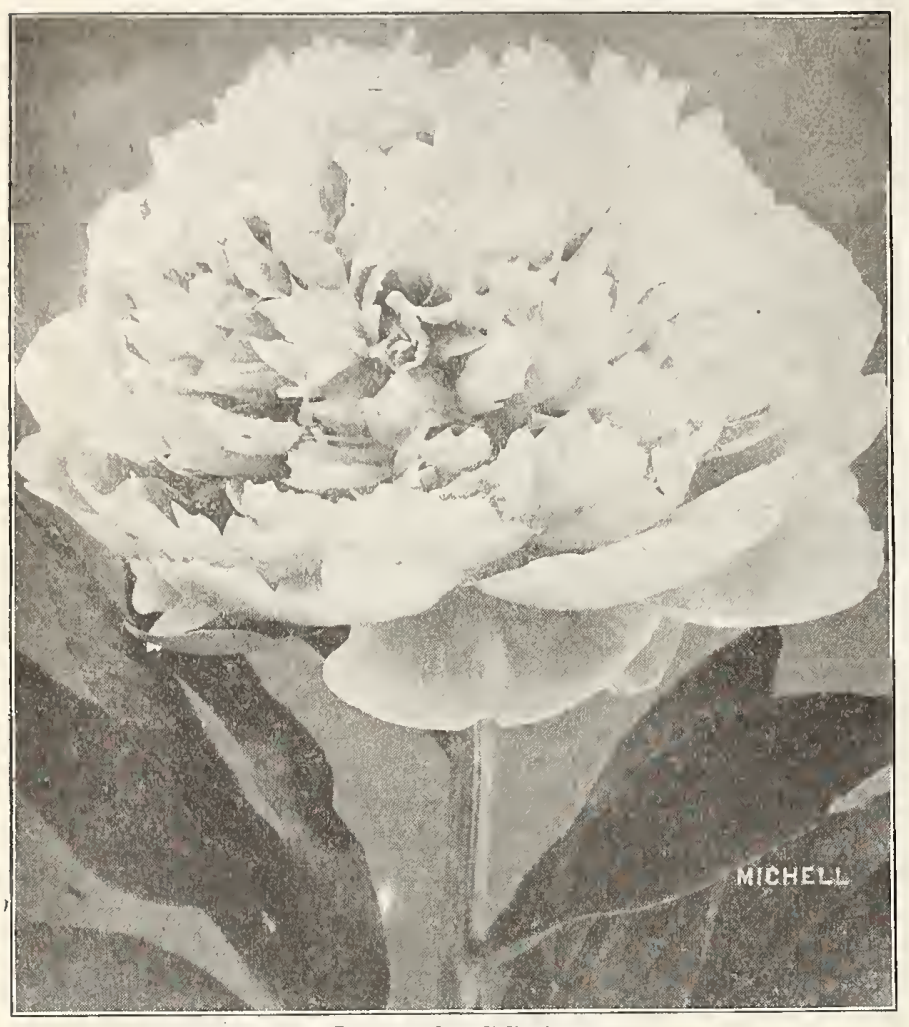

Paeony Candidissima

No disease or insect ever troubles this plant. They delight in a sunny location in deep rich soil. After planting take care to see they are watered regularly until you feel they are established. In planting always take care to see that the crown or top of root is not more than 1 to 2 inches below the surface when covered. Roots can be delivered beginning April or in the autumn beginning in September.

Achille. Beautiful shell-pink, changing to lilac

white; splendid variety. Early............\$0.25 \$2.50

Agnes Mary Kelway. White tinted rose, cream centre; a very striking flower. Early........
lba Plena. A giant flower of the purest white;

very double. Of superb fragrance. Mid-season.

Anemoneflora Rubra. Anemone form, having a

broad collar; beautiful dark crimson. Mid-season

Beaute Francaise. Lilac-rose, with a cream white collar; very fragrant. Mid-season..............

Berlioz. Perfect form. Large magenta rose color

Boule de neige. Very double, pure white; foliage is rich, deep green.

Candidissima. Creamy white, with a clear, sulphur-yellow centre. Early.

Carnea Elegans. Of a clear flesh color, glossy reflex. A free bloomer. Mid-season..............

Charlemagne. Excellent variety. Lilac, white, with a light pink centre. Fragrant. Late.....

Clarisse. Beautiful rose pink, with silvery pink centre; fine form and habit. Mid-season...... and deep pink edges on a few petals. Latc...

Delachi. Large flowers of a deep purple color, free bloomer. Late.

Delicatissima. Pale lilac rose, free habit; fragrant. Mid-season.

Duc de Cazes. Bright pink, silvery reflex. Early.

Duc de Wellington. Large, sulphur-white flower of great fragrance and with long stems. Late.

Duchesse de Nemours. Pure white, with a sulplur-white centre; very early; extra fine. Early Dr. Bretonneau. Lilac rose with cream white centre, flecked crimson. Mid-season............
Edulis Superba. Bright matuve pink, with narrow

2.50

$.30 \quad 3.00$
Eugenie Verdier. Giant globe-shaped flower of a Each Doz. soft pink color. Mid-season.............\$0.50 \$5.00

Faust, Delicate flesh pink, with salmon centre. Mid-season ...........................25 2.50

Felix Crousse. Large bright red flowers on long

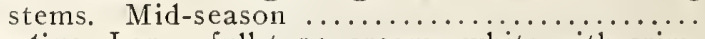

Festiva. Large, full type, creamy white with $\ddot{c} \ddot{m}$ son spots. Late bloomer..................

Festiva Maxima. Beautifully shaped flower, 7 to 8 in. in diameter. Pure white, splashed red. Late General MacMahon. Large anemone-shaped flower of a deep violet color. Mid-season...... Grandiflora Rosea. Full globe-shaped flower, light solferino red petals, salmon centre. Mid-season Lady Bramwell. Delicate silvery pink. Mid-seaLa Perle. Very large; globular; deep lilac white, blush centre prominently flecked carmine; frag-

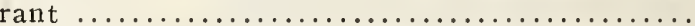

La Rosiere. Imbricated petals of yellowish white

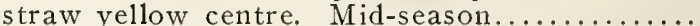

L'Eclatante. Large globular flower of brilliant red color; very good variety. Mid-season......

L'Indispensable. Perfect shaped flower of a delicate creamy color, shaded pink. Mid-season...

Louis Van Houtte. A rich shade of crimson maroon, an exceptionally fine large flower. Late. Marie Lemoine. Very large, compact flowers. Delcate white rose, with a creamy centre......

Meissonier. Loose reddish purple flowers on tall stems. Very fragrant. Mid-season...........

Mme. Calot. Pale hydrangea pink, centre shaded darker; collar tinted silver; free bloomer...... Mme, Forel. Very large compact flowers of light pink, with a silvery tipped centre. Late........

Mme. Leonie Calot. Delicate rosy white, centre petals slightly tipped carmine. Mid-season.....

Mons. Chas. Leveque. Rosy white, tipped carmine Mons, Krelage. Grand flowers of a dark pink color. Large and compact. Late............. $50 \quad 5.00$

Officinalis Alba. Double white. Very early. $\$ 0.30 \$ 3.00 \$ 20.00$ Officinalis Rosea. Double pink. Very early. $.30 \quad 3.00 \quad 20.00$ Officinalis Rubra. Double red. Very early.. .30 $3.00 \quad 20.00$ Queen Victoria. Pure white; cream centre. Mid- Each Doz.

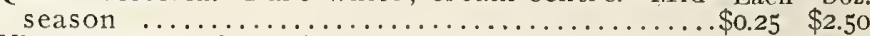

Victor Hugo.. One of the very best red paeonies.

Brilliant carmine red. Unsurpassed for cutting. . $.50 \quad 5.00$ Washington. Carmine, with lighter collar, tipped silvery; very fragrant. Mid-season........... $50 \quad 5.00$ Zoe Calot. Pure white; suffused rose. Mid-season $.25 \quad 2.50$

\section{DOUBLE TREE PAEONIES}

These very beautiful and free-flowering paennies deserve to be included in every collection. They are from 2 to 3 weeks earlier than any other variety and the flowers, often measuring a foot in diameter, include every shade from white and softest pink to the most brilliant scarlet and purple.

Japanese Tree Paeonies are usually grafted on Paeonia Moutan roots; and it is suggested that all side shoots, or suckers, be taken off, so the true or real type only will develop; otherwise the Paeonies will act as do Roses that are budded on briar.

Abraham Lincoln. Deep velvety amaranth; very double.

Beauty de Cologne. Salmon rose, suffused flesh coloreu.

3.50 Bijou de Chusan. Pure white, vellow centre, semi-double.

Confucius. A beautiful shade of purplish scarlet, single.

Etna. Brilliant fiery red.

Jeanne d'Are. Very large, salmon rose with dark centre, single.

Pure white, stiffused with delicate rose.

Louise Mouchelet. Beautiful silvery rose; extra large flower.

5.00 Queen of Belgians. Blush shaded salmon rose. Splendid sort. Rosea Superba. Salmon rose; semi-double. Beautiful.

$3.00 \quad$ Any of the above varieties, extra strong plants. $\$ 1.25$ each; per doz., $\$ 12.00$ (or 1 each of the above 10 varieties for $\$ 10.00$ ).

\section{PAEONIA TENUIFOLIA Flore Plena}

2.50 An early flowering species with fern-like foliage and double deep crimson flowers, a shade like the Jack Rose; this is undoubtedly one of the most attractive paeonies in cultivation, excellent for massing or planting individually in the herbaceous border, blooming very early in May, makes an exceedingly attractive plant. Each, 30c.; per doz., $\$ 3.00 ; \$ 20.00$ per 100

\section{PAEONIAS TO COLOR}

$.30 \quad 3.00$ 


\section{MICHELL'S HARDY PERENNIALS}

\section{PYRETHRUM}

Single Flowering, in choicest mixture. Embraces all shades. 25c. each; doz., $\$ 2.50$; $\$ 15.00$ per 100 .

Double Flowering. Mixed. 35c. each ; doz., $\$ 3.50$.

\section{RUDBECKIA}

Golden Glow. Double canary yellow; 6 feet : flowers in August.

Purpurea (Giant Purple Cone Flower). The Flowers from July to September; $21 / 2$ feet high.

Autumu Sun. A splendid single flowering sort; very showy.

Rays of Gold. An improved form of the well-known Golden Glow.

Price of above Rudbeckias, 20c. each ; doz., $\$ 2.00 ; \$ 12.00$ per 100 .

\section{SCABIOSA}

Caucasica A delicate shade of lavender blue; June to . September.

Caucasica Alba. White. Like the above, except the color.

Lutea Gigantea. Sulphur yellow; 6 feet; July-August.

Price of Scabiosas, 25e. each ; doz., $\$ 2.50$; $\$ 15.00$ per 100 .

\section{SEDUM (Stonecrop)}

Acre. The foliage of this is of a yellowish green shade. The flower, which appears in July, is bright yellow; height, 6 inches.

Album. Green foliage, white flowers: height, 6 inches.

Sexangulare (Love'en'tangle). Dark green foliage; yellow flowers ; 6 inches.

Sieboldii. Roundish foliage, with a blue cast; pink flowers.

Spectabilis. Foliage light green; immense heads of pink flowers. 25c. each; doz. $\$ 2.50 ; \$ 17.50$ per 100 .

Spectabilis Brilliant. One of the prettiest tall growing species, reaching a height of about 18 inches; broad light green foliage and richly colored flowers of amaranth red; September-October. 25c. each; doz.,

Price of any of the above, except where noted, $20 \mathrm{c}$. each; doz., $\$ 2.00 ; \$ 12.00$ per 100
SAPONARIA (Soap Wort)

Caucasica. Double white, tinted rose, flowering all summer; 15 inches high.

Oeymoides. A splendid plant for rock work, growing only 9 inches high; pink.

Either of the above, $20 \mathrm{c}$. each; doz., $\$ 2.00$; $\$ 12.00$ per 100 .

\section{SENECIO (Groundsel)}

Clivorum. A very effective plant with large green foliage and loose branching heads of bright yellow flowers; 3 to 5 feet high. 25 c. each ; doz., $\$ 2.50 ; \$ 17.50$ per 100 .

Pulcher. Brilliant rosy purple flowering on stems; 2 feet high. 25e. each; doz., $\$ 2.50$. Wilsonianus.
doz., $\$ 5.00$.

SOLIDAGO (Golden Rod)

Canadensis. Our native Golden Rod

Golden Wings. The finest of the Golden Rods.

Price of Solidagos, 20c. each; doz., $\$ 2.00$. $\$ 12.00$ per 100 .

\section{SPIRAEA (Drop Wort)}

Aruncus. A majestic plant, growing 4 to 6 feet high ; large plumy foliage and massive plumes of white flowers.

White plumes.

Filipendula fl. pl. Double white flowers and deeply cut foliage; $11 \frac{1}{2}$ feet; June and July.

Palmata (Crimson Meadow Sweet). Purplish red stems and crimson purple flowers ; 3 feet: June-July.

Venusta Magnifica. Rosy-red, fragrant flowers; 4 to 5 feet; June-July. 50c. each ; doz., $\$ 5.00$.

Price of above Spiraeas, except where 100.

100.

STATICE (Sea Lavender)

Principally grown for dried winter bouquets.

Gmelini. Immense panicles of flowers of delicate light blue color; 15 inches high July to October.

atifolia. Gigantic heads of dark blue flowers: June to October.

Tartarica. Deep lilac flowers, which appear all summer; 15 to 18 inches high. Price of the above, $20 \mathrm{c}$. each ; doz., $\$ 2.00$; Price of the
12.00 per 100 .

\section{STOKESIA (Cornflower Aster)}

The flower has the appearance combining giant cornflower and an aster. Plants are 18 inches high and are of spreading habit, blooming from June until frost. Succeeds in most any location.

Cyanea. Very light blue.

Cyanea Alba. Pure white.

Price of the above, 20c. each; doz., $\$ 2.00$; $\$ 12.00$ per 100

\section{VERONICA}

Amethystina. Amethyst blue flowers in June and July: 2 feet high.

Incana. White, silvery-like foliage, tufted with pale blue flowers; 12 to 18 inches.

Longifolia Subsessilis. Grows $21 / 2$ feet high and is completely studded with spikes of rich blue flowers from July to August. 25c. each; doz., $\$ 2.50 ; \$ 17.50$ per 100 .

Repens. Fine for rockeries or carpet bedding; light blue flowers; 6 inches.

Spicata. A very valuable species; dense tufts; erect spikes of blue flowers in June and July; 18 inches.

Spicata Alba. Similar to preceding, but with white flowers.

Virgimica. Free flowering, with bold upright habit, Pale blue; July and August.

Virginica Alba. Large, pure white.

Price of above Veronicas (except where noted), 20c. each; doz., $\$ 2.00 ; \$ 12.00$ per 100.

SPECIAL NOTICE ON GUARANTEE
We spare no effort to supply plants of
the best quality in first-class living con-
dition. On account of the many causes
beyond our control we regret we cannot
guarantee this stock to live and establish
itself, as that is usually entirely within
the power of the buyer or planter. If
customers desire us to guarantee plants
and shrubs to live we will assume such
guarantee at an advance of 25 per cent.
over and above our usual prices, but not
otherwise and such guarantee will expire
within 90 days from date of shipment.

\section{Michell's Climbing Plants, Vines and Roses}

Actinidia Arguta (Silver Vine). Beautiful dark green Each heart-shaped foliage ....................... $\$ 0.75$

Akebia Quinata. Quick growing vine.......... .30

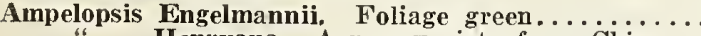
Henryana. A new variety from China.. Howilifolia. Dark glossy green foliage... Lowii (New Japanese Ivy) $\ldots \ldots \ldots \ldots$

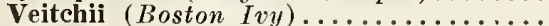

Aristolochia Sipho (Dutchman's Pipe)..........

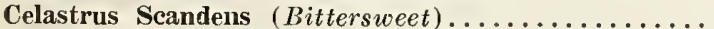

Clematis D. of Edinboro. Double white...........

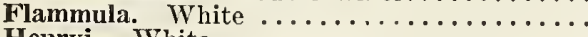

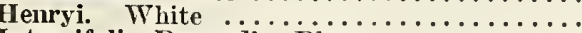

Integrifolia Durandi. Blue ............ Jackmauni. Purple ................. Mad. Baron Villard. Reddish purple......... Mad. Edw. Andre. Red $\ldots \ldots \ldots \ldots \ldots \ldots$ Montana Grandiflora. White ...............

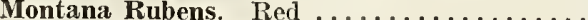

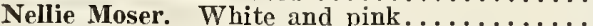

Sieboldi. Blue ..................

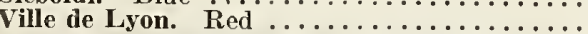

Euonymus Radicans Variegata. Self-clinging vine... Kewensis Vegetus. Dense foliage ....... Kewensis. Valuable for rockeries........... Radicaus. Deep green foliage............

Honeysuckle Chinese Evergreen (Woodbine)........ Halliana. Continuous bloomer.......... Heckrothi. Deep red flowers.......... Variegated. Beautiful mottled foliage..

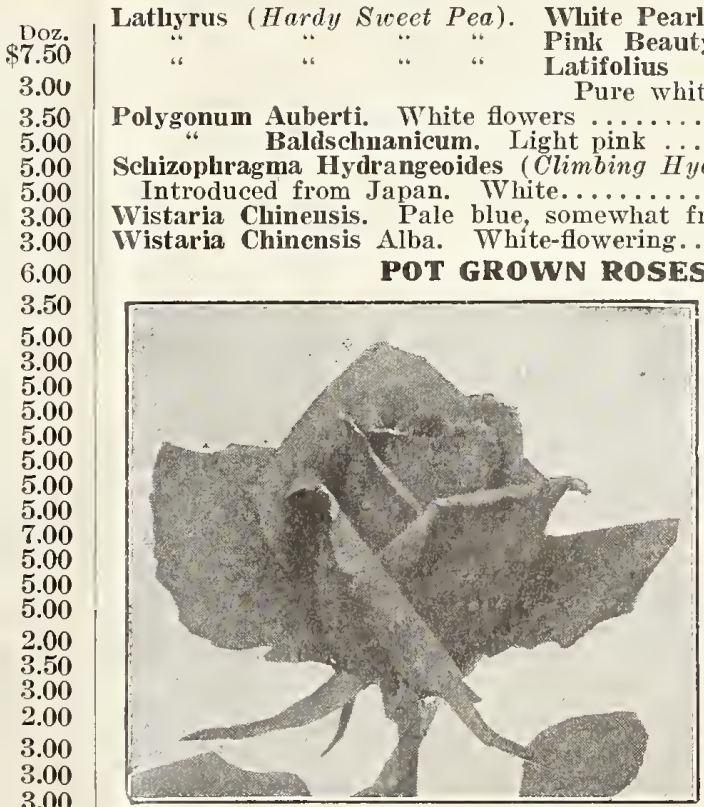

variety. Price, $60 \mathrm{c}$. e a c h ; doz., $\$ 6.00$.

$\begin{array}{cr}\text { Each } & \text { Doz, } \\ .30 & 3.00 \\ .20 & 2.00 \\ & \\ .20 & 2.00 \\ .75 & 8.00 \\ .75 & 8.00 \\ & \\ 1.00 & 10.00 \\ .60 & 6.00 \\ .60 & 6.00\end{array}$

We have a large collection left over from our s p ri ng stock; suitable for summer planting. They com prise
Climbers, Hybrid Teas, Teas, Dwarf Polyantha and $\mathrm{Hy}$ brid Perpetua 1 kinds. They are all named and labeled, but the quantity of any one variety is not large e $\mathrm{nough}$ to offer them to name, so we can agree to supply the types offered to color only, but labeled as 


\section{MICHELL'S SUPERB BULBS for Summer and Early Autumn Planting}

\section{EASTER IN 1919 COMES ON APRIL 20th}

ALLIUM Neapolitanum (Ready in August)

Used exclusively for indoor culture in pots and pans. It is especially adapted to forcing and makes an excellent cut flower; color pure white. Height, I2 inches. It is not hardy so cannot be planted outdoors. Dozen and Ioo lots mailed free. Each, 2c.; 20c. per doz.; per 100, \$1.25; \$10.00 per I000.

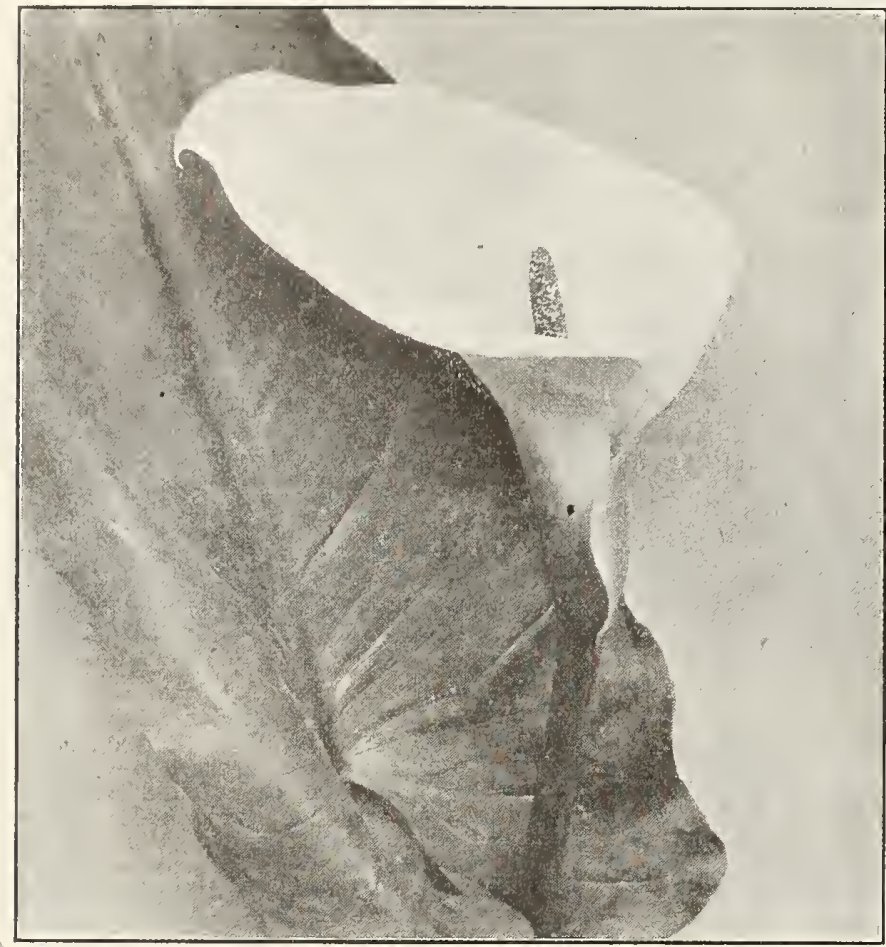

\section{CALLA LILY BULBS}

(Ready in September)

Callas require good, rich soil and plenty of warmth and water to make them thrive. Plant Callas indoors only. GODFREY DWARF EVERBLOOMING CALLA (New)

This comparatively new calla has proven an excellent one,

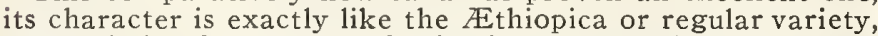
except it is of much dwarfer habit and freer bloomer; very desirable as a pot plant. Large blooming size bulbs, $20 \mathrm{c}$ each; doz., \$2.00; \$12.50 per IOO.

CALIFORNIA CALLAS

White, Monster Size

Each Doz. 100

\$0.50 $\$ 5.00 \quad \$ 35.00$

Medium Size ................ $.20 \quad 2.00 \quad 12.50$

First Size .................. . I5 I.50 10.00

Other varieties of Callas ready in October)

\section{FREESIAS (Ready in July)}

Purity. This is the grandest freesia ever offered. The flowers are almost twice the size of the regular type and of a pure glistening white; the stems are often I5 inches long and very wiry, rendering it a most valuable cut flower.

flower stems. Each Doz. $100 \quad 1000$ First Size Bulbs .............. \$0.04 \$0.30 \$I.75 \$15.00 Mammoth Size Bulbs ............. .05 .50 $3.00 \quad 25.00$ Monster Size Bulbs ............. .06 .60 $4.00 \quad 35.00$ Jumbo Bulbs ................... . IO I.00 $5.50 \quad 45.00$

French. Fine variety; pure white with yellow throat.

First Size Bulbs ............\$0.04 $\$ 0.30$ \$1.75 12.50 Mammoth Size Bulbs ............. .05 $.35 \quad 2.00 \quad$ I7.50 Monster Size Bulbs ............... $.06 \quad .50 \quad 3.00 \quad 25.00$

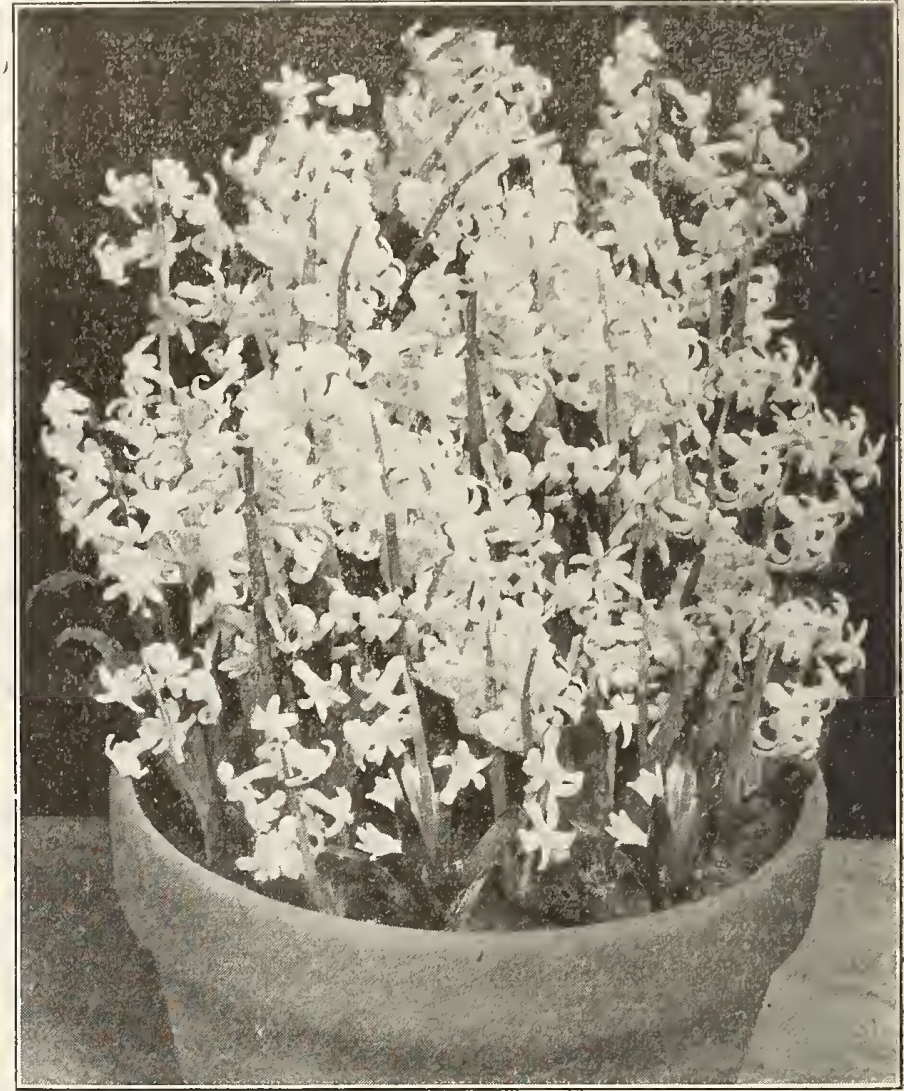

Michell's Monster White Roman Hyacinths

FREESIA "MICHELL'S RAINBOW"

Light Pink, Dark Pink, Yellow and Orange, Light Blue, Lavender, Mauve, Yellow and Purple; All colors mixed. On account of the war we are unable to furnish these this season.

\section{FRENCH ROMAN HYACINTHS}

\section{(Ready in August)}

French Roman Hyacinths afford a continuous supply of bloom from early winter until late in spring if planted in succession (two weeks apart). They are very fragrant.

They are easily grown in pots or pans. The bulbs, if potted in August or September, the pots plunged in the open ground for a month, until the bulbs are well rooted, and then brought in the house, they can be had in flower in November or December, and a continuous supply of these delightful flowers may be had, by bringing in a few pots or pans of the rooted bulbs at intervals of about 2 weeks. The bulbs should be planted quite close together, a 6 -inch pot or pan will be sufficiently large enough for six bulbs. They are not hardy and are not suitable for outdoor planting.

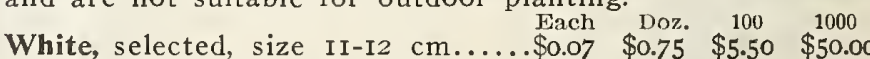

“ Extra'select, size I2-I5 cm.. .IO I.00 6.5060 .00

" Mammoth, I3-I5 cm........ .I2 $1.25 \quad 7.50 \quad 67.50$

"Monster, I5 cm. and over...

Light Pink ..................... .07 $.75 \quad 5.50$

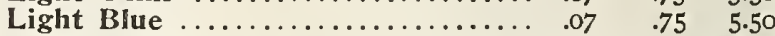

White Italian. Late; large spikes.. $.07 \quad .75 \quad 5.50$

Parcel post weight, I lb. per doz.; per Ioo, 8 lbs.

\section{TESTIMONIAL FROM JAPAN}

The bulbs arrived here this morning per parcel post. They were all in perfect condition. Let me express my thanks for the careful execution of my order.

Yours truly,

F. OYAMA, 49 Fushi Midai, Dairen. 


\section{MICHELL'S EARLY POLYANTHUS NARCISSUS}

Paper White Grandiflora, First Size Bulbs. This is quite a specialty with us; of it alone we import over one million bulbs. It is a pure white flowering sort; used extensively for forcing, as it can be 'brought into bloom in 8 weeks' time; the stems are very long and it is excellent for bunching. 6c. each; doz., 45c.; \$2.75 per I00; per 1000, $\$ 25.00$.

Paper White Grandiflora, Mammoth Bulbs. 8c. each; per doz., 60c.; $\$ 4.00$ per 100 ; per 1000, $\$ 32.50$.

Paper White Grandiflora, Giant Bulbs. Ioc. each; doz., 75c.; $\$ 5.00$ per I00; per I000, $\$ 40.00$.

Double Roman. White perianth, with an orange and yellow suffused cup; very free flowering and early. 6c. each; per doz., 50c.; $\$ 3.50$ per I00; per 1000, $\$ 30.00$.

Grand Soleil d'Or. Rich yellow, with deep red cup. For cutting this is a fine variety, as it makes a grand show. $7 \mathrm{c}$. each; doz., 75c.; $\$ 5.00$ per 100.

Other varieties of Narcissus ready in September)

\section{MICHELL'S EARLY TRUMPET NARCISSUS}

Extra Early Golden Spur. For Christmas and New Year's forcing this strain is far in the lead of the regular Dutch type. Free flowering, producing rich, golden yellow blooms. 7c. each; doz., 75c.; $\$ 5.00$ per 100.

French Trumpet Major (Christmas Flowering). A beautiful early flowering yellow variety. They force easily and can be had in flower without any trouble for Christmas. 6c. each; doz., 60c.; $\$ 4.00$ per 100 ; per 1000, $\$ 35.00$.

\section{LILIUM CANDIDUM}

\section{(Ready in August)}

This variety is sometimes called St. Joseph's, Madonna or Annunciation Lily. One of the most popular and satisfactory of the American garden lilies. Pure waxy white flowers produced on straight stems bearing anywhere from io to 30 blooms of good size and substance; delightfully fragrant.

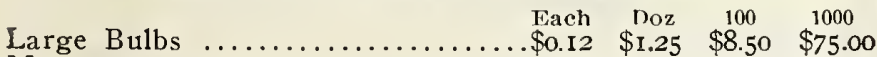
Mammoth Bulbs ................. 15 .15 1.50 10.00 85.00 Monster Bulbs .................... $20 \quad 2.00 \quad 12.50 \quad 100.00$ Other Lilies will be offered in our September Catalog.

\section{OXALIS}

(Ready in July)

For conservatory, greenhouse and window garden culture the Oxalis is ideal.

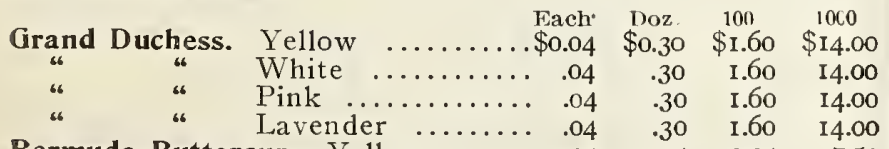
Bermuda Buttercup. Yellow ........ Other Oxalis Ready in September)

\section{ORNITHOGALUM ARABICUM} (STAR OF BETHLEHEM)

(Ready in August)

A favorite white, spring-flowering bulb; plant in October for outdoor use, or in September for indoor blooming. Large bulbs: Each, 6c.; 50c. per doz.; per I00, $\$ 3.50 ; \$ 25.00$ per 1000.

\section{COLD STORAGE LILY OF THE VALLEY}

Every gardener at odd times requires this exquisite flower for table decorations or other occasions. Our stock is the best procurable, and can be supplied at any time during the entire year in lots of not less than Ioo. They can be brought into flower in from 25 to 30 days with little or no trouble. Michell's Giant Flowering Strain. Price on application.

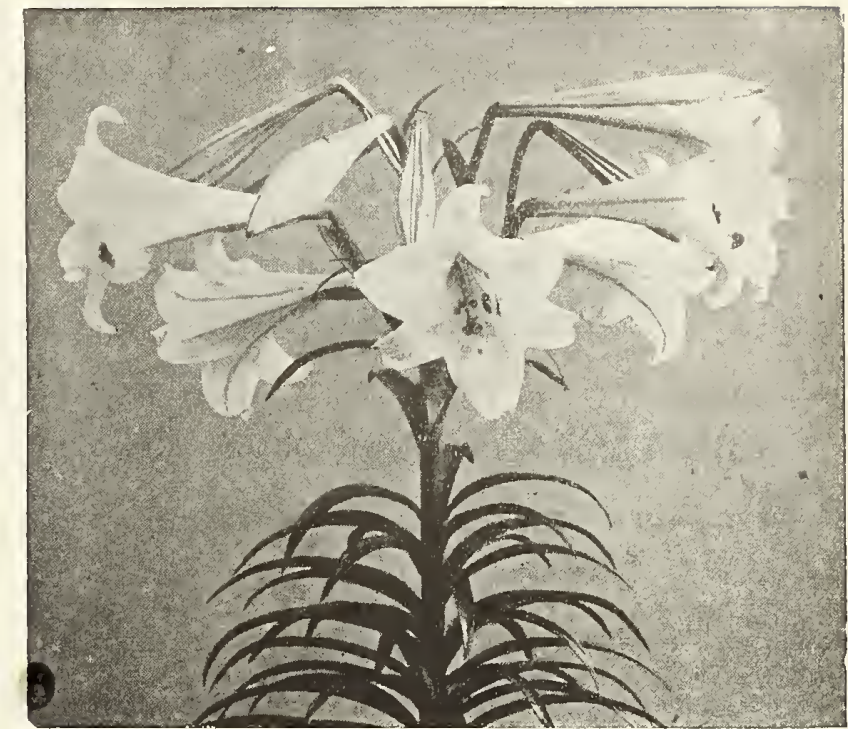

Michell's Superb Easter Lilies

\section{MICHELL'S "SPECIAL BRAND" LILIUM HARRISH}

\section{(True Bermuda Easter Lily) (Ready in August)}

Noted for freedom from disease, uniformity and free flowering qualities.

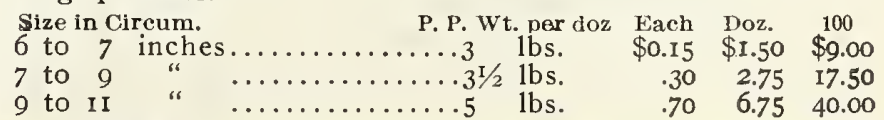

\section{LILIUM LONGIFLORUM MULTIFLORUM}

MICHELU'S SPECIAL BRAND (Ready in October)

This brand must not be compared with lower priced bulbs, as it is a distinct selection.

\begin{tabular}{|c|c|c|c|c|c|c|}
\hline & & $\begin{array}{l}\text { P. P. Y } \\
\cdots \cdots 3^{I}\end{array}$ & $\begin{array}{l}\text { t. per doz. } \\
\text { lbs. }\end{array}$ & $\begin{array}{l}\text { Each } \\
\$ 0.20\end{array}$ & $\begin{array}{l}\text { Doz } \\
\$ 2.00\end{array}$ & $\begin{array}{r}100 \\
\$ 12.00\end{array}$ \\
\hline IO & & $\cdots 4$ & lbs. & .25 & 2.25 & I 5.00 \\
\hline I0 & “ & & lbs. & .30 & 2.75 & 17.50 \\
\hline ster & Bulbs & 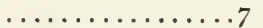 & lbs & .75 & 7.50 & \\
\hline
\end{tabular}

\section{LILIUM FORMOSUM}

(The Formosa Easter Lily)

Similar to the Bermuda Lily, but blooms earlier. Dark Stemmed Type

(Flowering generally in March and April.)

\begin{tabular}{|c|c|c|c|c|c|c|c|}
\hline to & & & $\begin{array}{l}\text { Weig] } \\
\ldots .3^{1}\end{array}$ & $\begin{array}{l}\text { per doz. } \\
\text { lbs. }\end{array}$ & $\begin{array}{l}\text { Each } \\
\text { \$0.25 }\end{array}$ & $\begin{array}{l}\text { Doz. } \\
\$ 2.25\end{array}$ & $\begin{array}{c}100 \\
\$ 15.00\end{array}$ \\
\hline 0 IO & & & $\cdots 5$ & lbs. & .30 & 3.00 & 20.00 \\
\hline 12 & & “ & …... & lbs. & .50 & 5.00 & 37.50 \\
\hline er & Bulb & & $\ldots \ldots 9$ & lbs. & 1.00 & 10.00 & \\
\hline
\end{tabular}

Monster Bulbs ............... 1... 10.00

Green Stemmed Type

(Flowering generally in January, February and March.) 6 to 8 inches circum. .......2 $2^{\mathrm{I} / 2}$ lbs. 7 to 9 " " $\quad \ldots \ldots \ldots .3^{1 / 2}$ lbs. $\quad .20 \quad 2.2513 .50$

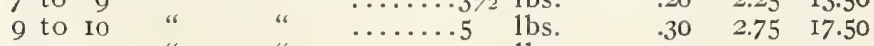
I0 to 12 " $\quad$ " $\ldots \ldots \ldots .7$ lbs. $\quad .50 \quad 3.00 \quad 22.50$ Monster Bulbs .............9 lbs. $75 \quad 7.50$

LILIUM LONGIFLORUM GIGANTEUM (True) $\begin{array}{lll}6 & \text { Weight per doz. Each Doz. } 100\end{array}$ 6 to 8 inches................2 $2^{\mathrm{I} / 2}$ lbs. \$0.12 $\$ 1.25 \$ 7.50$

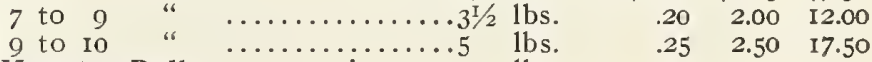

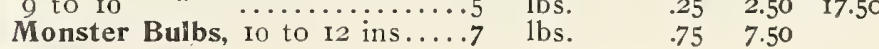




\section{${ }^{12}$ MICHELL'S DISTINCTIVE FLOWER SEEDS \\ FOR SUMMER AND EARLY FALL SOWING}

\section{For Complete List of Flower Seeds see our General Catalogue for 1918}

ACHILLEA (Mntroll or Yarrow)

Large Pkt. Pkt.

Ptarmica, FI. PI., "The Pearl." Tall erect plants; pure white double flowers; hardy perennial; $2 \mathrm{ft} . \$ 0.50$ \$o.10

\section{ACONITUM (Mons's Hood or Hemlet Flower)}

Hardy perennial, thriving best in semi-shady situations; curious hood-shaped flowers in clusters; 4 feet; AugustSeptember.

Napellus, Blue Large Pkt. Pkt.

AGROSTEMMA (Rose or Heaveu, Mulletn Pmk)

Coronia. Erect growing plants with silvery foliage and crimson flowers; hardy perennial; $2 \mathrm{~T} / 2$

to 3 feet ............................... . I5

\section{ALYSSUM}

Large Pkt... Pkt.

Lilac Queen. Dwarf and compact; flowers lilac. \$0.40 \$0.10

Little Dorritt. Extremely dwarf and compact, with miniature white flowers............. 9oz.

Little Gem. Dwarf compact plants, densely covered with large pure white flowers; height, 4 inches.............................. $75 \mathrm{c}$.

Lutescens. Dwarf and compact; yellow flowers.. .40

Saxatile Compactum (Basket of Gold). Showy golden yellow flowers; hardy perennial; I ft. oz., goc.

Sweet. Of trailing habit, with pure white flowers; 6 inches............................. 30c.

\section{AMPELOPSIS (Boston or Japrnese Ivy)}

Veitchi. A hardy perennial climber with olive green leaves, which turn to scarlet in the autumn ............................., 40c.

\section{ANCHUSA (Sea Bugloss))}

Italica "Dropmore." A hardy perennial plant, 4 feet high, with flowers of a lovely gentia

ANEMONE (wind Flower)

A dainty spring flower with bright cup-shaped blossoms; splendid for cutting; perennial. Large Pkt. Pkt. Coronaria Mixed. All colors; I foot............\$0.20 \$0.05 St. Brigid, or Poppy. Flowers of large size; semidouble and double; I foot.................. .40 .I5

\section{ANTHEMIS (Hardy Marguerite)}

Tinctoria Kelwayi. A handsome hardy perennial; daisy-like bright yellow flowers; 2 feet...... .30

\section{AQUILEGIAS OR COLUMBINES}

A graceful spring flowering plant; exquisitely spurred flowers on stems 2 feet above the fern-like foliage.

Large Pkt. Pkt Californica Hybrida. Mixed colors; long spurs..\$0.40 \$o.Io Chrysantha. Bright golden yellow............. .50 Chrysantha Alba. Purest white.............. .50 Coerula (Rocky Mountain Columbine). Large flow-

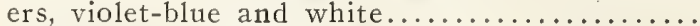
Haylodgensis Delicatissima. Satiny rose..........50 Long Spurred Hybrids. Flowers of many rich and

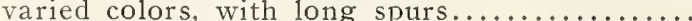

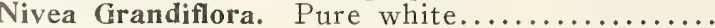
Double Mixed ............................... $60 \mathrm{c}$. Single Mixed ......................., 6oc.

\section{ARABIS (Rock Cress)}

Alpina. Early spring flowering perennial; especially, adapted for edging and rockery; plants form a dense carpet completely covered with pure white blossoms; 6 inches..................
ARMERIA (See Pink or Thrtr) Large Pkt. Pkt Formosa. A pretty hardy perennial for edgings; rosy pink flowers; 9 inches................. 30 .IO

\section{ANTIRRHINUM (Snяpdragou)}

A splendid plant for beds or borders and one of our choicest cut flowers; extensively forced under glass during the winter.

\section{MICHELL'S GIANT ANTIRRHINUMS}

Spikes, 2 to 3 feet in length, with giant flowers.

Michell's Giant Salmon Pink. Long spikes of arge Pkt. Pkt delicate salmon pink color...............\$0.50 \$0.15 Silver Pink. A fine variety; long spikes and a

profuse bloomer. Original pkt., \$I.00.

Giant Garnet ............................ . .

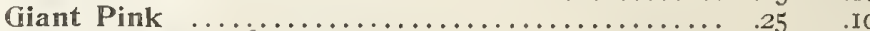

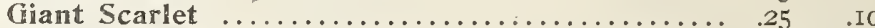

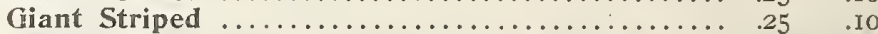

Giant White $. . \ldots \ldots \ldots \ldots \ldots \ldots \ldots \ldots \ldots \ldots \ldots . .25$. 10

Giant Venus. Shell pink on white ground....... .40 .I5

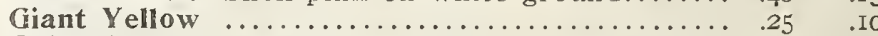

Collection, one packet each six colors. $50 \mathrm{c}$

Giant Mixed. All colors................oz., 90c. .20 . I0

ANTIRRHINUMS-Various Sorts

The Semi-Dwarf sorts grow about 18 inches high, with large flowers over most of the stem.

Semi $=$ Dwarf. Bride. Pure white............\$o.3o \$o.Io

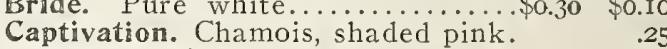
Defiance. Fiery scarlet............25 .IO Golden Queen. Golden yellow, giant flowers $\ldots \ldots \ldots \ldots \ldots \ldots \ldots \ldots \ldots, .25 \quad .10$ Mauve Beauty. Rosy mauve...... .30 Nelrose. Pink ....................$^{50} \quad .25$ Pink Gem. Rose pink........... .25 Queen of the North. Of purest

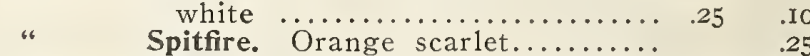

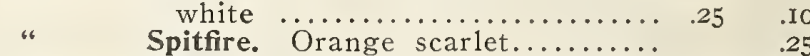
Tall Mixed. Regular strain................., 9oz., 60c. .20 . 15 " $\quad \begin{aligned} & \text { white } \ldots \ldots \ldots \ldots \ldots \ldots \ldots \ldots \ldots . .25 \\ & \text { Spitfire. Orange scarlet........... }\end{aligned}$ Tom Thumb Mixed. All colors; i2 inches....... .25

\section{ASPARAGUS}

100 Seeds Pkr

Hatcheri. Of dense and symmetrical growth; valuable for decorative use, also for specimen pot plants ............................. \$1.00 \$0.25

Plumosus Nanus. An excellent plant for house or conservatory decoration $\ldots \ldots \ldots \ldots \ldots \ldots \ldots \ldots . .1 .00 \quad .25$

Sprengeri. One of the best plants to grow in hanging baskets for greenhouse in winter or for outdoors in the summer................50 .I0

\section{ASPERULA (woodrufr)}

Odorata. Dwarf spring flowers of purest white, thrives in shady situations; perennial; I ft.; May .30

\section{ASTER, PERENNIAL (Michaelmas Datsy)}

Choice Mixed. A showy perennial plant; starlike single flowers; 2 to 3 feet............... \$0.30 \$0.10

\section{AURICULA (Primula AurteuIa)}

Choice Mixed. These early flowering perennial plants resemble primroses and have multi-colored flowers in great variety; 6 inches..........

\section{BOCCONIA (PIume Poppy)}

Cordata. A splendid hardy perennial, with glaucous green foliage and spikes 2 to 3 feet long of

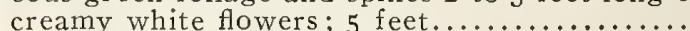

\section{BROWALLIA}

Elegant free flowering plants; blooms finely in the winter if the plants are lifted and cut back; 18 inches.

Large Pkt. Pkt. Speciosa Major. Large ultramarine biue flowers; desirable as a pot plant for winter and spring

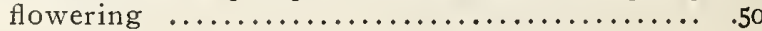




\section{CALCEOLARIA}

Our strains of Calceolaria have a wide reputation as to large size, rich and varied colors of the flowers.

Hybrida Grandiflora, Tall Mixed. Large flower- Large ing, rich, self-colored flowers saved from a Pkt. Pkt. choice collection; 18 inches...............\$0.75 \$0.25

Hybrida Grandiflora, Pumila Compacta. Of dwarf, compact growth; trusses of large, self-colored

James' Superb Strain. A robust grower, producing very large and beautiful flowers; 18 inches. 1.25

Sutton's Perfection. Choicest mixed. Original

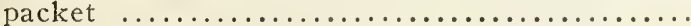

CALLIOPSIS (сотеорвіs)

California Sunbeams. Large flowers beautifully formed; various shades of yellow and brown..

Lanceolata Grandiflora. Single golden yellow flowers of graceful form; invaluable for cutting; flowers uninterruptedly the entire summer .............................., 5oc.

CAMPANULA MEDIA (Canterbury Bell)

Showy, hardy biennial growing about 3 feet high, with large bell-shaped flowers. Sow from June rst till September Ist; after frost has set in protect with leaves and straw.

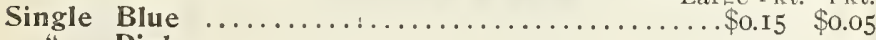
Large Pkt. Pkt.

Pink ..................................

White

.05

Mixed

Double Mixed

CAMPANULA CALY CANTHEMA (cup and saucer)

These produce beautiful, large single flowers, resembling a cup and saucer; they require the same treatment as above.

Blue Large Pkt. Pkt.

Pink

White

Mixed

\section{CAMPANULAS OR BELLFLOWERS PERENNIAL VARIETIES}

These are among our best known hardy perennials; the tall varieties are fine for cutting while the dwarf sorts make excellent border plants; all have dainty bell-sliaped flowers.

Carpatica, Blue (Carpathian Hare Bell). Compact tufts not exceeding 8 inches; flowers clear blue, Large pkt. held erect; blooms in June and July..........\$0.20 \$0.05

Carpatica, Alba. Pure white................. 20.05

Persicifolia Grandiflora, Blue $(P e a c h$ Bells $)$. Spikes, 4 feet tall with blue bell-shaped flowers.......

Persicifolia Grandiflora, Alba. Pure white.........

Pyramidalis (Chimney Bell Flower). Perfect pyramids 6 feet high crowded with large bell-shaped flowers, blue and white mixed...

\section{CANDYTUFT (Iberis)}

Sempervirens. Dwarf spring flowering perennial; flowers glistening white; May; I foot....

\section{CARNATION}

Desirable for greenhouse culture in winter as well as for the garden in summer.

Chabaud's Everblooming Mixed. Blooms in five Large

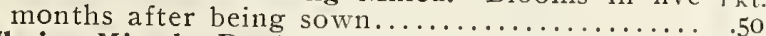

Choice Mixed. Double border.................... 5

Early Vienna. Large double flowers in choicest

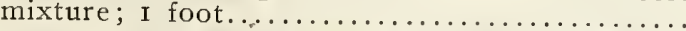

\section{MARGUERITE CARNATIONS}

Excelsior Mixed. Immense flowers in all the

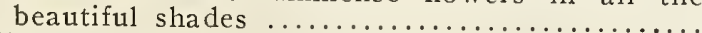
Pink

White

Scarlet

Yellow

Choice Mixed ....................... \$1.25 $\quad .25$

Ask for Cultural Leafiet No. 2 I3 on the growing of Car $^{\text {I }}$ nations from seed.

\section{CENTAUREA (Perennial)}

Large feathery flowers; splendid for cutting; blooms from July to September.

Montana. Blue; I foot Large Pkt. Pkt.

CERASTIUM (snow in summer)

Tomentosum. Dwarf, white-leaved edging plant; flowers white; perennial; 4 inches.

$.40 \quad .15$

\section{CHRYSANTHEMUM (Perennial)}

Mrs. C. Lothian Bell. Immense pure white flowers

Frutescens Grandiflorum (Paris Daisy or Marguerite). Single flowers, white with yellow cen-

Shasta Daisy, "Alaska." The finest of all; single white flowers on long stems; 2 feet............ King Edward VII. Flowers extra large; pure Japanese Hybrids. Large flowers of the finest types; an extra choice mixture; seed sown in spring will produce flowering plants by fall; I8 inches

\section{CINERARIA}

Our Grandiflora Prize Strain is the best procurable, producing immense trusses of the largest flowers, often measuring up to 4 inches across. Large Pkt. Pkt. Grandiflora Prize Dwarf. Mixed colors........\$0.75 \$0.35 Grandiflora Prize Medium Tall. Mixed colors.... $\quad .75 \quad .35$ Sutton's Superb. Mixed colors. Original pkt.... I. Matador. Large bright red flowers........... .75 .35 Hybrida. Choice mixed colors .................... 65 .25 Radiata Hybrida. Small, star-like flowers...... .75 .20 Stellata (Sutton's). Medium sized: star-like flowers. Original pkt.

Stellata Hybrida. Mixed colors................................... Ask for Cultural Leaflet No. 203 on the growing of Cin= erarias.

\section{CLEMIATIS}

Flammula. Feathery-white, fragrant flowers.... \$o.I5 \$0.05 Jackman's Large Flowering. Mixed; saved from the finest, large flowering sorts.................... white, star-shaped flowers. $40 \quad .15$

\section{CYCLAMEN}

\section{MICHELL'S "DISTINCTIVE" GIANT}

Grown for us in England by a Specialist who has received numerous First Prizes for the large size and beatiful coloring of the flowers.

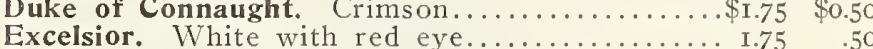
Grandiffora Alba. White....................

Princess of Wales. Pink.................. I.75 .50

Salmon Queen. Salmon pink................. 1.75 .50

Mixed. All colors ......................... I.50 .40

.05

\section{Mrs. Buckston. Frilled and waved flowers; color} delicate salmon. Original pkt....

Papilio (Butterfly). The edges of the flowers are beautifully fringed, or waved; mixed colors.... $1.50 \quad .40$ leaves margined with silver.

Sutton's Giant. Choicest mixed. Original pkt.........

Ask for Cultural Leaflet No. 2 I5 on the growing of clamen.

DAISY, ENGLISH DOUBLE (Bellis Perennis)

Seed should be sown from June Ist till September, transplanted in the fall, and they will flower in the following spring. If sown in the spring they will flower in the autumn; 4 inches. $\quad$ Large Pkt. Pkt. Longfellow. Large double pink flowers.......... \$0.40 \$0.10 Monstrosa, Pink. This strain produces the largest and most perfectly double flowers of any variety $\quad .65 \quad .25$ Monstrosa, White ......................... .65

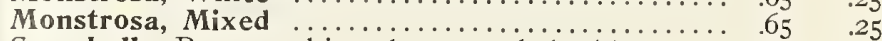

Snowball. Purest white; large and double......... .40 .Io

Double Mixed ............................4. 40 
DELPHINIUM (Hardy Larkspur)

One of the finest hardy perennials; easily grown from seed; effective in beds, masses or borders. Large Pkt. Pkt. Belladonna. One of the most continuous blooming varieties; large spikes of clear turquoise blue; 5 feet................................... $\$ 0.25$

Chinense Grandiflorum. $\mathrm{A}$ dwarf strain with loose branches and sprays of bright blue flowers; 2 feet ................................. goc. Chinense Grandiflorum Album. Pure white flow-

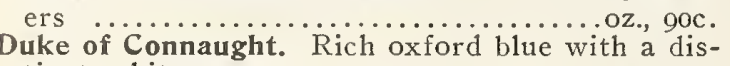
Elatum (Bee Larkspur). Rich blue; 4 feet.oz., $\$$ i.5o Formosum. Deep blue ; feet...........oz., \$1.00 Formosum Coelestinum. Sky blue................ Kelway's Giant. Plants are of strong, vigorous
growth, with immense spikes of large flowers; many shades of blue; 5 to 7 feet...............

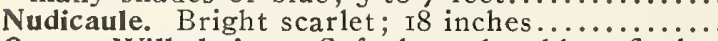

Queen Wilhelmina. Soft lavender blue, flushed

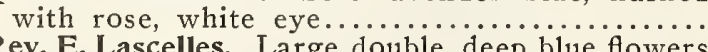

Rev. E. Lascelles. Large double, deep blue flowers with white centre.................................. DIANTHUS (Hardy Garden PInks)

Clove Scented. Double and semi-double varieties, in beautiful colors; fragrant................... Double Scotch. Choice mixed colors.............

Pheasant's Eye. Single white fringed flowers with dark centre ............................. 60c.

DICTAMNUS (Gas Plant)

Fraxinella. Showy bushy plants $2^{\mathrm{T} / 2}$ feet high, purple red flowers; perennial; June and July...

\section{DIGITALIS (Forglove)}

Ornamental hardy plants; long spikes of beautiful tubularshaped flowers; blooms during June and July; 4 to 5 feet.

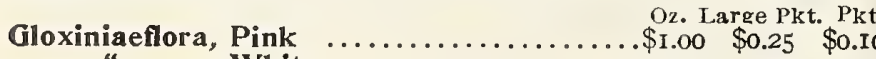

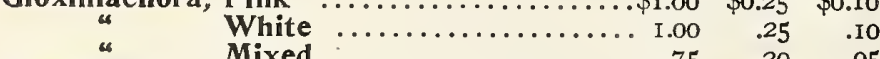

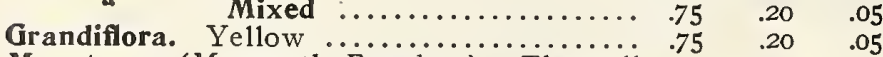

Monstrosa (Mammoth Foxglove). The tall spikes are surmounted by one monstrous flower; all colors mixed.

\section{EUPATORIUM}

Fraseri. Tall bushy plants with loose heads of feathery white flowers; perennial; 2 feet.......

\section{FERNS}

Very desirable plants for ferneries.

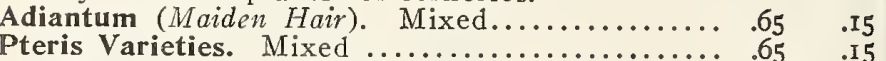

Pteris Varieties. Mixed .................... .65 .I5

We can also furnish all other varieties of fern spores.

GAILLARDIA (Blanket Flower)

One of the most showy of hardy perennials; spikes of gorgeously colored flowers of immense size.

Grandiflora Compacta. A compact variety; cholarge Pkt. Pkt. mixed colors; i2 to Is inches . choice

Grandiflora Sanguinea Blood $\mathrm{red}$.............\$0.20 \$0.10

Grandifora Semi=Double. Mixed ..............30

Grandifiora Sulphurea Oculata. Sulphur yellow,

Grandiflora Superba. Splendid mixed, 2 feet. oz., $60 \mathrm{c}$.

GENTIANA (Blue Gentlan)

Acaulis. Dwarf hardy perennial; deep blue flowers; suited to moist, shady situations..........

\section{GEUM}

Atrosanguineum Fl. Pl. Hardy perennial with large, showy, double, dark crimson flowers; $I^{1 / 2}$

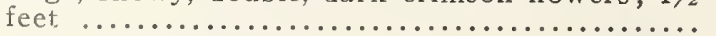

GOLDEN ROD (Solldago Canadensis) A well-known hardy perennial; deep golden yellow flowers $; 2$ feet......................

\section{GYPSOPHILA (Baby's Breath)}

Large l'kt. Pkt.

Paniculata. Hardy perennial; flowers in graceful

sprays of white; 2 feet.................. 75c.\$0.20 $\$ 0.05$

Paniculata, Fl. Pl. Double white.............. 20

HELENIUM (Sneeze-Wort)

Autumnale Superbum. Perennial; large heads of

golden yellow flowers; 5 to 6 feet.............. .30 .Io

HELIOPSIS (orange Sunflower)

Pitcheriana. A handsome hardy perennial; deep orange yellow flowers; excellent for cutting; 3

to 4 feet..................................... .

HEUCHERA (Alum Root)

Sanguinea. Splendid plant; spikes of vivid crimson flowers; excellent for cutting; I foot.......

$.50 \quad .10$

HIBISCUS (Marshmallow)

. So Showy plants; large, beautiful bell-shaped flowers; perennial.

Crimson Eye. Large white flowers with crimson

Large Pkt. Pkt

centre; 4 feet ...................... 75c. $\$ 0.20$ \$0.10

Golden Bowl. Giant yellow, maroon centre..... .25 .IO

Moscheutos. Rosy red with dark centre.......... .I5 05

New Giant (Mallow Marvel). Mixed................. .30 .I5

\section{HOLL YHOCK}

A popular and desirable hardy perennial plant; excellent for planting among shrubbery or forming a background for other flowers; 6 to 7 feet.

Allegheny. Semi-double; mammoth flow- Oz. Large Pkt. Pkt. ers, edges fringed and laciniated; mixed.\$1.00 \$0.25 \$0.10 Chater's Double Maroon ............... $1.25 \quad .30 \quad .10$

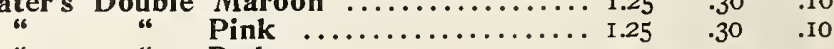

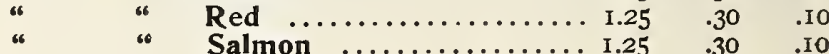

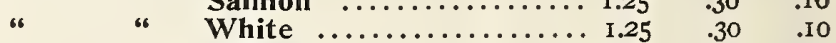

" $\quad$ " $\quad \begin{aligned} & \text { Yellow } \ldots \ldots \ldots \ldots \ldots \ldots \ldots \ldots \\ & \text { " }\end{aligned}$

Collection, one packet each of above 6 colors....... $\quad .50$

Double Ever=blooming Mixed. Colors range from white to deep black, yellow, pink,

red and purple $\ldots \ldots \ldots \ldots \ldots \ldots \ldots \ldots \ldots \ldots$. $1.25 \quad .30 \quad .15$

Single Ever=blooming Mixed .............. $1.00 \quad .25$.10

Single Mixed ....................... I.00 .20 .

IRIS (Flowering Flag)

Kaempferi (Japanese Iris). Perennial; blooms the second year from seed; mixed colors........... .I5 .I0

\section{LATHYRUS LATIFOLIUS (Everlasilng ox}

Free flowering, hardy perennial climber with clusters of flowers resembling Sweet Peas; excellent for cutting. Oz. Large Pkt. Pkt.

Crimson. Brilliant .................\$0.60 \$0.20 \$0.10

Pink Beauty. Bright rosy-pink........... I.00 .25 .10

White $\ldots \ldots \ldots \ldots \ldots \ldots \ldots \ldots \ldots \ldots \ldots \ldots \ldots, .90 \quad .15$.10

Choice Mixed. All colors ................ 75 .75 20 .05

\section{LAVENDER (Lavendula vera)}

Well-known perennial plant bearing long spikes

of fragrant blue flowers; 18 inches............. .25 $\quad .05$

\section{LOBELIA}

Cardinalis (Cardinal Flower). Hardy perennial; tall spikes of bright scarlet flowers, very showy $\quad .50$.10 LUPINUS (Luptns)

Seeds sown in greenhouse during the late summer and fall months will produce an abundance of bloom for winter.

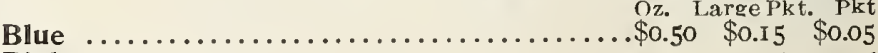

Pink ................................ . .05

Scarlet, White Tipped ................... .50 . I5 .05

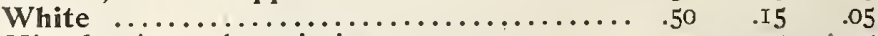

Mixed. Annual varieties...................40 .I5 .05 LUPINUS (Perennial Varieties)

Polyphyllus Blue ........................ \$0.15 $\$ 0.05$

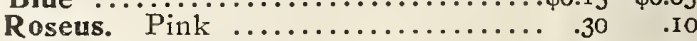
Somerset. Yellow $\ldots \ldots \ldots \ldots \ldots \ldots \ldots \ldots$. 40 . 40 White $\ldots \ldots \ldots \ldots \ldots \ldots \ldots \ldots \ldots \ldots \ldots$.I 5 . 05

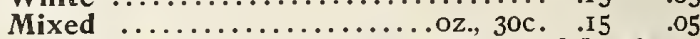
05 Ask for Cultural Leaflet No. 217 on the culture of Lupinus. 


\section{LYCHNIS}

Perennials of easy culture; most effective in beds or borders. Arkwrightii (New). Many shades and colors in Large Pkt. Pkt.

Chalcedonica (Rose Campion). Fine scarlet cross-

like flowers; 2 feet; July................oz., 50c.\$0.I5 .05

Haageana. Brilliant, large, orange, scarlet, pink,

or crimson flowers; mixed, I foot; July........ .5

\section{MIGNONETTE}

Seed may be sown at intervals during the summer for a succession of bloom; may also be forced in greenhouses during the winter.

Allen's Defiance. Spikes invariably attain a height

of 12 to I5 inches; deliciously fragrant..oz., 60c.\$0.20 \$0.Io

Bismarck. Compact plant of strong growth; stout

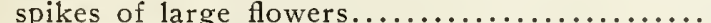

Golden Machet. Large golden yellow....oz., 5oc.

Goliath. Giant spikes of brilliant red flowers.... 20

Michell's Colossal. Flower-spikes often averaging

I8 inches; extremely fragrant..................
Machet. Large reddish tinted, sweet scented

flowers ..................................... 5oc.

Miles' Spiral. Flowers whitish.............., 40c.

Parsons White. Fragrant white. flowers.oz., 40c.

Sutton's Giant. Reddish buff. Original pkts.....

Sweet Scented. The popular garden sort.oz., I5c.

.25 .IO

20 .IO

$.50 \quad .15$

I5 .IO

$.15 \quad .05$

.55

.40

.05 onette.

\section{MYOSOTIS (Forget-Me-Not)}

Neat little plants with star-shaped flowers; for spring flowering sow in July or August.

Alpestris Victoria. Of bushy habit; bearing large Parge Pkt.

bright blue flowers; very fine; 6 inches........ $\$ 0.30$ \$o.Io

Dissitiflora. Attractive deep blue flowers......... .50

Eliza Fanrobert. Large flowering, bright blue... .30

Grandiflora Alba. Large white flowers; 8 inches. .30

Grandiflora Rosea. Large pink flowers; 8 inches. .30

Palustris. The true Forget-Me-Not; bright blue

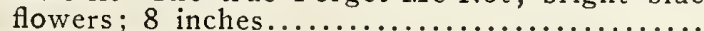

Palustris Semperflorens. Dwarf; blooms the entire

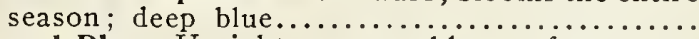

Royal Blue. Upright grower; blue; I foot.........

Ruth Fischer. A compact plant with light blue flowers; splendid for pots....................

Choice Mixed. Various shades of blue, rose and

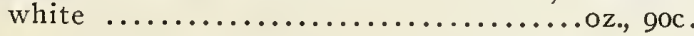

\section{Michell's Giant Pansies}

Seed sown in frames during July and August and transplanted later gives us the main crop of flowers the following spring.

\section{PANSIES IN MIXTURES Large}

Michell's Giant Exhibition. A blending of our own containing only the very choicest secured from the leading Pansy specialists; flowers of immense size, very heavy texture and of the most brilliant colors. Per oz., \$10.00; \$3.00 per

Triumph of the Giants Mixed. Immense flowers $1 / 8$ oz., $\$ 1.75 \ldots \ldots \ldots \ldots$ of great brilliancy and richness of coloring, including many new and rare shades. Per oz., $\$$ II.00; \$3.25 per I/4 Oz.; per $1 / 8$ oz., \$2.00.........

Bugnot, Odier and Cassier. A superb mixure of giant blotched varieties........... I $/ 8$ oz. $\$$ I.00

Giant Trimardeau. Very large flowering; all colors mixed $\ldots \ldots \ldots \ldots \ldots \ldots \ldots \ldots \ldots$. $/ 4$ oz., $\$ 0.75$ Mad. Perret. Early flowering, fragrant, especially rich in red shades............... I $1 / 4$ Oz., \$1.25 Masterpiece (Frilled Pansy). Flowers beautifully curled or waved.................. I $/ 8$ oz., \$I.00

Odier or Blotched. Beautiful strain.. $1 / 8$ oz., $\$$ I.00 Parisian Large Stained. Choice colors. $1 / 8$ oz., \$1.00 Finest English Mixed....................., \$I.50 .75 .50 $.65 \quad .25$ $.40 \quad$.IO $.65 \quad .25$ $.65 \quad .25$ $.65 \quad .15$ $.50 \quad .15$ Very Fine Mixed............................, $\$ 1.25$.30 $\quad .25$.IO Ask for Cultural Leaflet No. 209 on the growing of Pansies.
GIANT PANSIES-Separate Color's

Giant Prize Azure Blue. Violet blue...... $\$ 1.25$ Q Large Fkt. Pkt.

Black Blue. Dark velvety..... I.25 .50 .I5

Emperor William. Ultramarine

$\begin{array}{cccc}\text { blue } \ldots \ldots \ldots \ldots \ldots \ldots \ldots \ldots & \text { I.25 } & .50 & \text {.I5 } \\ \text { Hortensia Red. Scarlet....... } & \text { I.25 } & .50 & \text {.I }\end{array}$

King of the Blacks. Black... $1.25 \quad .50 \quad .15$

Lord Beaconsfield. Violet....

Peacock. Upper petals blue,

lowęr petals deep claret; white margin ............. I.25

Snow Queen. Pure white.... I.25

Striped and Mottled............. I.25

White with dark eye........ I.25

Pure Yellow .................. 1.25

Yellow with dark eye.......... I.25

$.50 \quad .15$

$.50 \quad .15$

$.50 \quad .15$

$.50 \quad .15$

$.50 \quad .15$

SPECIAL OFFER: We will send 6 packets of any of the above varieties of Giant Pansies for $75 \mathrm{c}$.; or the entire 12 pkts. for $\$ 1.40$.

PANSIES-Regular Sorts in Separate Colors

Belgian Striped. Showy............. \$2.50 $\$ 0.30$ \$0.I0

Emperor William. Utramarine blue....... 2.50 .30 .IO

Faust (King of the Blacks). Almost black .2.50 $\quad .30$.IO

Gold Margined. Purple, golden edge.....2.50 .30 .I0

Havana Brown .....................2.50 .30 .I0

Lord Beaconsfield. Violet............. 2.50 .30 .I0

Mahogany Colored ..................... 2.50 .30 .I0

Silver Edged. Purple, silver edge........ 2.50 .30 $\quad$. Io

Snow Queen. Pure white............... 2.50 .30 .Io.

White with dark eye................ 2.50 .30 .I0

Yellow Gem. Pure yellow.............. 2.50 .30 .I0

Yellow with dark eye................... 2.50 .30

SPECIAL OFFER: We will send 6 packets of any of the above varieties of regular sorts of Pansies for 50c.; or the entire I2 packets for $90 \mathrm{c}$.

PENTSTEMON (Beard Tongue)

A perennial plant producing large spikes of flowers.

Barbatus Torreyi. Spikes of brilliant coral red, very effective; 3 to 4 feet................. \$0.30 \$0.Io Sensation. Large spikes of gloxinia-like flowers of brilliant colors; 2 feet; requires protection. 40 .I5

Mixed. Choice colors; 3 feet................... $.25 \quad .05$

\section{HARDY PHLOX}

Decussata. Plants 2 feet high; flowers in all bright colors; sow seeds late in fall and they will germinate in the spring.....................

PHYSOSTEGIA (False Dragou Head)

A pretty hardy perennial, bearing freely, delicate tubular flowers; 3 to 4 feet; July-August. Iarge Pkt. Pkt.

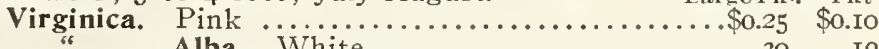

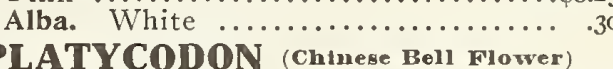

PLATYCODON (Chinese Bell Flower)
desirable perennial; 2 to 3 feet. Large Pkt. Pkt. A very desirable perennial; 2 to 3 feet. Large Pkt. $^{\text {Pkt. }}$

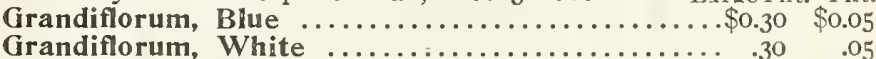
Japonicus Fl. Pl. (Double Japanese Bell Flower).

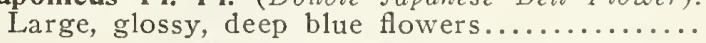

\section{POLYANTHUS (Primula Elatior)}

Gold Laced. Flowers of brilliant colors, with dis-

tinct yellow edge.

Double Mixed. Beautiful colors.

$.50 \quad .15$

English Mixed.

\section{POPPY (Peremnial)}

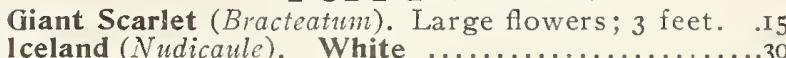
Yellow

Double Mixed

Single Mixed

Orientale.. Extra large flowers; deep scarlet.....

Beauty of Livermere. Crimson with

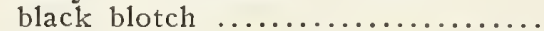

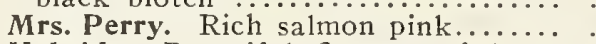
Hybrids. Beautiful flowers of large size, mixed colors.....................
$.50 \quad .15$

30 .IO

5. .IO

$30 \quad .10$

.30 . . IO

$30 \quad .10$

25 .IO

$50 \quad .10$

$50 \quad .10$

$.30 \quad .10$ 


\section{PRIMULA}

\section{FRINGED CHINESE PRIMROSE}

Our strains are unsurpassed and have won many first prizes.

Michell's Prize Mixture. This mixture contains Large only the very finest sorts selected from the best Pkt. Pkt. strains ............................ \$0.75 \$0.25 Alba Magnifica. White flowers with yellow eye... $\quad .75 \quad \begin{array}{r}40 \\ 0\end{array}$ Chiswick Red. Brilliant red ................... .75 ${ }_{4} 40$ Duchess. Large; white with zone of rosy carmine, yellow eye........................

Kermesina Splendens. Crimson.

Pink Pearl (Neres) Brilliant

Rosy Morn. Delicate pink.

Stellata (Sutton's). Excellent pot plant; mixed...

Fern Leaved. Choicest mixed colors............

\section{PRIMULA OBCONICA GIGANTEA}

A great improvement over the old type; flowers much larger, and produced in greater abundance. Large l'kt rkt. Alba. White ............................... 65 \$0.20 Kermesina. Crimson ...................... 65 .20

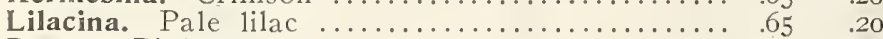

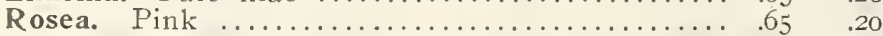

Hybrida Mixed

\section{PRIMULA OBCONICA GRANIIFLORA}

Compacta. Compact plants with rosy lilac flowers Crispa. Flowers large, curled; color, from apple

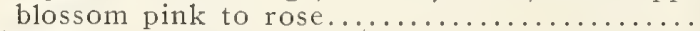

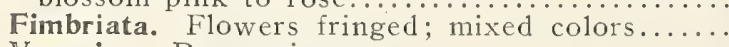

Vesuvius. Deep crimson. .

\section{PRIMULA - Various Sorts}

Buttercup. Yellow flowers; fine for pots........... Kewensis ( Verbena Scented Yellow Primrose).
Spikes each I2 to I 8 inches long; color, soft yel-

Malacoides. Resembles Primula Forbesi; flowers larger; if grown in greenhouse will bloom in four to five months' after sowing; light lilac.... Malacoides Alba. Flowers pure white.............

Malacoides Rosea. Light rose to carmine rose...

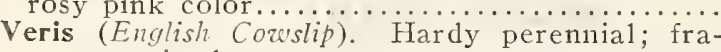

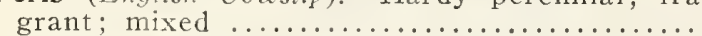

Vulgaris (English Primrose). The common hardy

English variety; canary yellow................ . .

Ask for Cultural Leaflet No. 206 on the growing of Primulas.

\section{PUERARIA THUNBERGIANA (Kudzu vime)}

One of the fastest growing hardy climbing plants; $\begin{gathered}\text { Large } \\ \text { Pkt. Pkt. }\end{gathered}$ rosy purple pea-shaped blossoms...............20 \$0.Io

\section{PYRETHRUM (Perenmial)}

Roseum. Flowers bright rose color; July; 2 feet. Uliginosum. Large, single white flowers; September; 3 to 4 feet.......................................... white to light pink and deep red, with bright

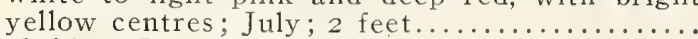
Hybridum Double Mixed

\section{RUDBECKIA (Coneflower)}

Newmani. Large yellow flowers with black centre; perennial; 2 feet; all summer............. Purpurea (Giant Purple Cone Flower). Hardy perennial; reddish purple flowers, with dark brown disc; 3 feet

\section{SALVIA}

Azurea Grandiffora. Hardy perennial producing during August and September spikes of pretty sky-blue flowers; 2 feet........................... Farinacea. A perennial variety, but best treated
as an annual; color, light blue; 2 feet.........

$30 \quad .10$

\section{SCABIOSA}

Handsome perennial border plants, flowering the entire season. Caucasica. Soft blue Large Pkt. Pkt. .

Caucasica Alba. Pure white................. .50 .I0

Japonica. Lavender blue ................... .20 .I0

\section{SCHIZANTHUS (Bntterfly Flower)}

One of our finest annuals, bearing a profusion of pretty butterfly-like flowers of various colors; desirable for winter blooming in pots.

Grandiflorus Maximus. Flowers extra large, and Płkt. Pkt. of various colors ...................... \$0.25

Hybridus Grandiflorus. Compact plants, with

flowers of many shades of orchid-like appear-

ance; I2 inches.......................... Io

Pink Beauty. A beatutiful shade of rose pink... $\quad .40$

Wisetonensis. A showy variety, largely used as a pot plant for the house or conservatory; flowers range from white with yellow centre to pink with brown centre....................... $.50 \quad .20$

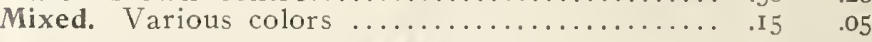

\section{SMILAX}

desirable greenhouse climber of great value for floral decorations; seed should be soaked 24 hours in warm water before sowing....oz., 6oc.

STATICE (Everlastlng Flower)

65.25 Latifolia. Hardy perennial variety, with large,

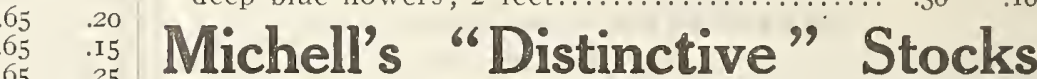

The seeds we offer are hand-saved from pot-grown specimens and will produce a large percentage of double flowers.

MICHELL'S "NICE" STOCK

An early flowering strain; remarkable free bloomer; large double, fragrant flowers; fine for cutting. For winter blooming, sow from July to September. large Pkt. Pkt. Abundance. Dwarf spreading habit; color, car-

mine rose .............................. $\$ 0.15$

Beauty of Nice. Delicate soft pink............. .40 .I5

Crimson King. Brilliant fiery crimson............. .40 .I

La Brilliante, Rich brilliant crimson............40 .I5

Midsummer Night. Deep dark violet............ .40 .I5

Mme. Rivoire. Early flowering; pure white........ .40 .I5

Queen Alexandra. Delicate lavender............. $40 \quad .15$

Victoria. Pure white .......................4 .4 .I5

Choice Mixed, All colors................... .40 .I5

\section{MICHELL'S FLOWER MARKET STOCK}

This is the ideal stock for either garden, cutting or forcing under glass. Plants branch freely and produce from io to 15 heavy spikes of extra large perfect flowers; height, 2 feet.

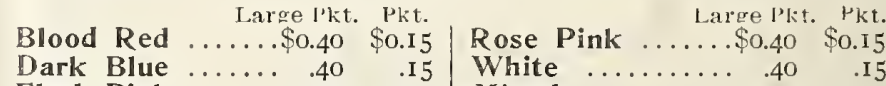

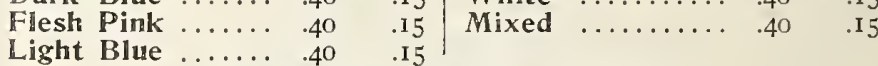

\section{MICHELL'S COLUMN STOCK}

Stout plants produce just one giant spike, lined, with mammoth flowers; height, 3 feet. Large Pkt. Pkt Blood Red ................................ \$0.15

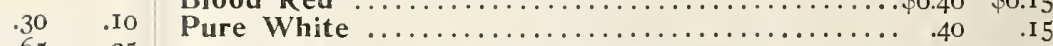
LARGE FLOWERED DWARF TEN-WEEK STOCK

Large Pkt. Pkt.

Blood Red ..... \$0.30 \$0.10

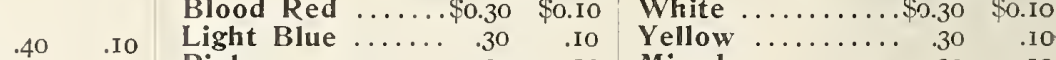

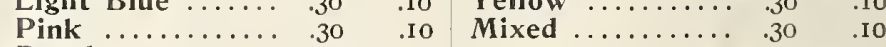
Purple ........... .30 .Io

Bismarck. Immense pure white flowers......... .40 .I5 Brompton or Winter. Fine for forcing under glass or early summer flowering outdoor......... . . . Princess Alice (C $u$ t-and-Come-Again). Branching .30 .Io plants with double pure white flowers......... $.40 \quad .10$ Wall=flower Leaved. Choice mixed................4. . Ask for Cultural Leaflet No. 2 II on the growing of Stocks. 


\section{Winter Flowering Spencer or Orchid Sweet Peas}

Asta Ohn. Rich lavender.... Pkt. Oz.

.$\$ 0.25 \$ 1.75$

Lavender Nora

Lavender Pink Orchid.

Mrs. A. A. Skaach. Clear, light pink............ I5 1.25

Mrs. M. Spanolin. Pure white................. I5 I.25

Mrs. William Sim Orchid. Salmon pink......... I5 I.25

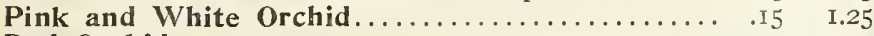

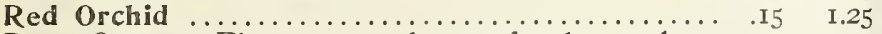

Rose Queen. Flowers are borne freely on long stems, are of large size, and usually four flowers are produced on a stem. Color a most attractive shade of pink............. I/4 oz., \$I.50.

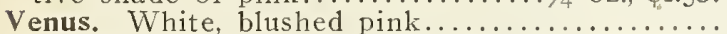

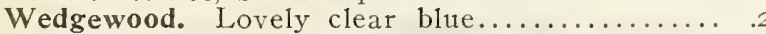

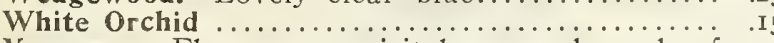

Yarrawa. Flowers exquisitely waved, and of large size, many of them being duplex or double.

Color, a pleasing shade of bright rose pink with

lighter wings

Mixed Colors

\section{EARLY FLOWERING LONG SEASON SPENCER SWEET PEAS}

One of the chief characteristics of these varieties is their long-season period of blooming, frequently remaining in bloom for four months. The flowers are of large size, of the best Spencer form, and are borne in threes and fours on long stems.

Early Heatherball. Mauve lavender..........\$o.I5 \$1.25

Early Hercules. Soft rose pink...............25 1.75

Early Liberty. Deep sunproof crimson.......... $.25 \quad$ I.75

Early Meadow Lark. Rich cream...................... 1.75

Early Melody. Rose pink on white ground...... .I5 I.25

Early Morning Star. Deep orange scarlet in

standard, with rich, orange-pink wings......... .I5 I.25

Early Snow Flake. Large pure white............ I5 I.25

Early Song Bird. Pale pink on white ground.... .I5 I.25

Early Songster. Rich lavender................... $.25 \quad 1.75$

Early Spring Maid. Light pink on white ground .I5 I.25

Early Sunset. Rich, mauve pink on white ground .25 I.75

Early Warbler. Rich, mauve purple..............25 I.75

\section{MICHELL'S CHRISTMAS OR WINTER FLOWERING SWEET PEAS}

Michell's Snowdrift. Pure white; black

seeded: extra early................... \$o.Io \$0.25

Christmas Meteor.. Scarlet ................. .10 $\quad .20$

Pink. Pink and white..............

White (Florence Denger)

Earliest of All. Pink and white............ .

Le Marquis. Large dark blue.............. .

Mont Blanc. Pure white................

Mrs. Alex. Wallace. Lavender.............. I0

Mrs. Chas. H. Totty. Lavender............. Io

Mrs. F. J. Delansky. Daybreak pink...... Io

Mrs. William Sim. Salmon pink.......... IO

Watchung. Pure white....................

Mixed. Winter flowering .............. . I0 .20

STOKESIA (Cornflower or Stokes' Aster)

A very desirable hardy perennial plant, bearing freely from July to October handsome Centaurea-like blossoms; $I^{1} / 2$ to 2 feet.

Cyanea. Light blue ....................\$0.25

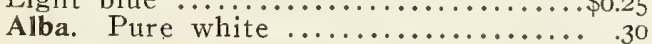

Pkt.

\section{SUNFLOWER (Hellanthus)}

Showy perennials blooming all summer.

Golden Bouquet. Single yellow flowers; 5 feet.. .30

Choice Mixed. Single flowering............... 40

SWEET ROCKET (Hesperis)

Mixed. Fragrant white and purple flowers; perennial; 2 to 3 feet........................
SWEET WILLIAM (Dinthus Barbatus)

One of the finest hardy garden plants; of easy culture, and lasting for years. The plants grow about $\mathrm{I}^{\mathrm{I} / 2}$ feet high.

Auricula Flowered. Single mixed...........

Single Crimson .................... oz., \$0.60. .I5 .05

Pink Beauty. Salmon pink.................... .15

Scarlet Beauty. Deep scarlet...........40 .I5

Velvety Maroon ................., \$0.6o. . I5 .05

White ....................., \$0.60. .I5 .05

Mixed. All colors..............oz., \$0.40. .I5 .05

Double Mixed ......................... \$I.00. .20 .IO

VALERIANA (Garden Il eliotrope)

Hardy perennial border plants; fragrant flowers; 2 to $3 \mathrm{ft}$. Mixed Large Pkt. Pkt.

\section{VERONICA (speedwell)}

An elegant hardy perennial of easy culture; valuable as a cut flower or for garden effect.

Larce Pkt. Pkt.

Spicata. Bright blue; I8 inches..............\$0.30 \$0.10

\section{VIOLA CORNUTA (Turted Pansies)}

These resemble pansies in shape and form, with the additional quality that they have long stems, and bloom from early spring till late in fall. - Large Pkt. Pkt. Admiration. Dark blue .................. \$0.50 \$0.Io Mauve Queen. Lovely mauve color............ .50 .Io Perfection. Light blue.....................50 . Io White Perfection. Pure white..................

Mixed. All colors..........................40. . .

VIOLA (Scotch Beddiug Pansles)

These are very free flowering and cannot be surpassed for bedding purposes; produce larger flowers than the Viola

Golden Gem. Yellow...................... $\begin{aligned} & \text { Large Pkt. } \\ & \text { \$o.I5 }\end{aligned}$

Lutea Splendens. Rich golden yellow........... .50 . I0

Snowflake. Pure white..................... $.50 \quad .15$

Mixed. From the best named Scotch varieties... $\quad .65 \quad .25$

\section{VALLFLOWER}

While these are perennials, they are not perfectly hardy; the plants should be lifted late in the fall and planted in a cold-frame, and removed to the garden again in the spring; the flowers are fragrant and splendid for cutting; double varieties, 2 feet; single varieties, $\mathbf{I}^{\mathrm{I} / 2}$ feet.

Double Brown

$$
\begin{aligned}
& \text { Yellow } \\
& \text { Mixed. Ail colors. }
\end{aligned}
$$$$
\text { Large pkt. \$o.t. }
$$

"Mixed.

Single Mixed

Imported Collection..........................., 30c. I5 double varieties..05

Imported Collection. 6 single varieties............. .40

Paris Extra Early. A single-flowering variety, which may be treated as an annual flowering the first year from seed.

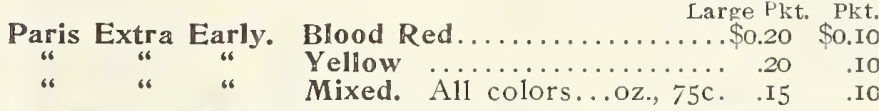

\section{MICHELL'S COLLECTION OF HARDY PERENNIAL FLOWER SEEDS}

I8 Varieties. Special Price, \$1.25. One packet each of the following:

Alyssum Saxatile.

Aquilegia, Single Mixed Hopho,

Calliopsis. Lanceolata Grand- Lobelia. Cardinalis. iflora.

Campanula. Pyramidalis.

Delphinium. Formosum.

Dianthus. Clove Scented.

Digitalis. Gloxiniæflora.

Mixed.

Gaillardia. Grandiflora.

Poppy. Orientale.

Pyrethrum. Single Mixed.

Rudbeckia. Purpurea.

Scabiosa, Caucasica.

Stokesia. Cyanea.

Sweet William. Double.

Mixture of Perennial Flowers

\section{MICHELL'S PERENNIAL FLOWER GARDEN MIXTURE}

To create an old-fashioned wild garden or to naturalize along roads or woods we highly recommend this mixture, as it contains many hundred varieties of the choicest oldfashioned flowers. Pkt., Ioc.; 40c.' per oz.; per I/4 1b.; $\$$ I.25. 
For complete list see our General Seed Catalogue, mailed free on request

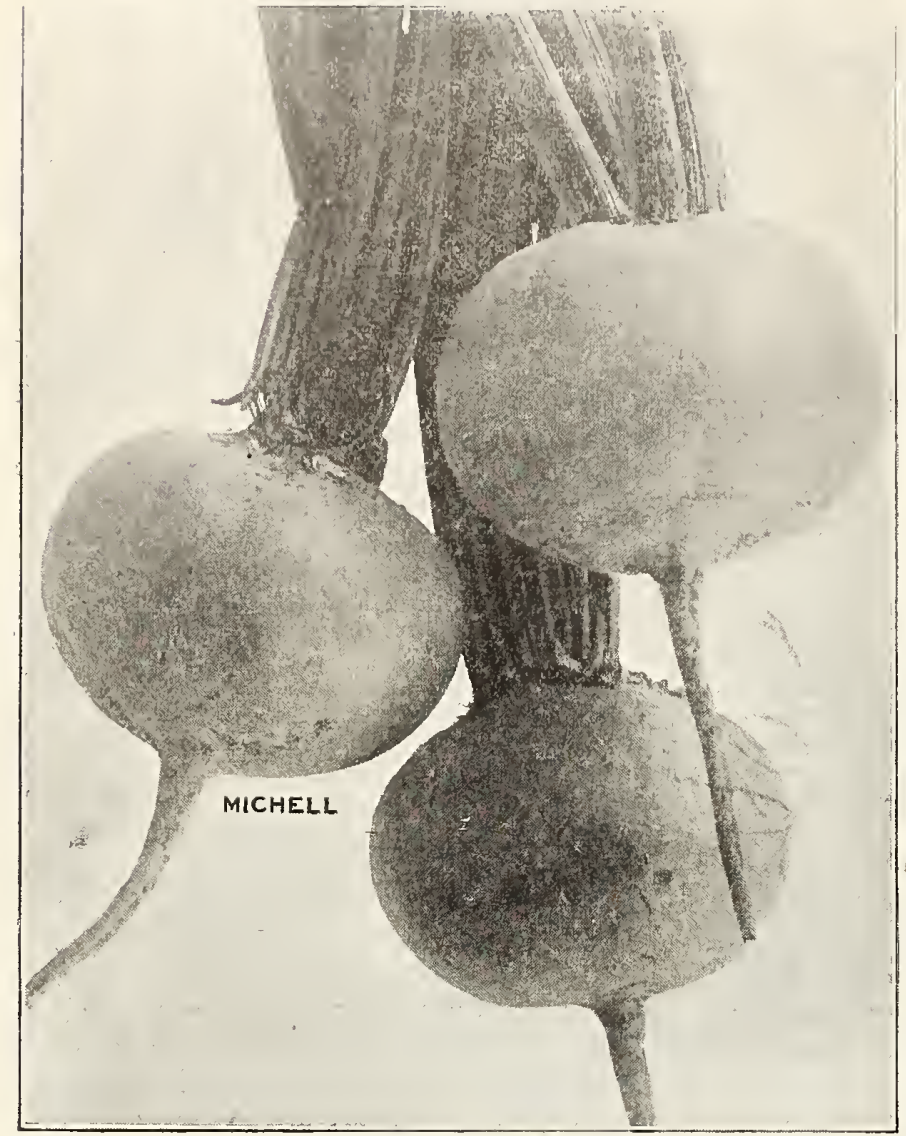

Beet, Crosby's Egyptian

\section{BEET-Table Varieties}

Pkt. Oz. 1/4 ib. Lb.

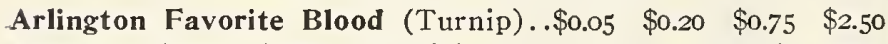

Bassano Extra Early (Turnip)......

Bastian's Half Long Blood.......... . .05 $\quad$.I5 $\quad .60 \quad 2.00$

Crimson Globe (Michell's Improved). $\begin{array}{lllll}.05 & .25 & .75 & 2.50\end{array}$

Crosby's Egyptian (Turnip) ........

$\begin{array}{lllll}\text { Detroit Dark Red (Turnip).......... } & .05 & .20 & .75 & 2.25\end{array}$

Eclipse Extra Early (Round)....... $.05 \quad$.I5 $\quad .60 \quad 2.00$

Edmand's Blood (Turnip)............ .05 . . 5 .60 2.00

Swiss Chard. Giant Lucullus.......

\section{BEANS-Green Podded, Dwart Varieties}

Large Packets of all varieties Ioc. postpaid.

Parcel Post Weight of Beans: I pt. equals I 1b.; I qt. equals 2 lbs.

Pt. Qt.

Boston Navy or Pea...................\$0.30 \$0.60

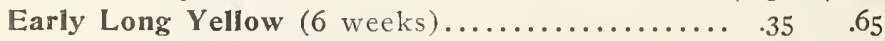

Early Mohawk (6 weeks)...................... .65

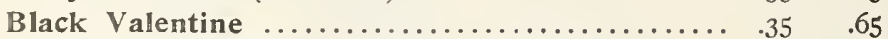

Mammoth Stringless or Giant Valentine......... $45 \quad .85$

Red Valentine .............................40 .45

Stringless Green Pod..................... .40 $\quad .75$

Stringless Green Pod Improved................ $.45 \quad .85$

Sion House (for forcing)..................... $50 \quad 1.00$

White Kidney or Royal Dwarf................ .30 $\quad .60$

White, Marrowfat (used shelled)................ $\quad .30 \quad .60$

BEANS-Wax or Yellow Podded

Black or German Wax.................. $\$ 0.45 \quad \$ 0.85$ Currie's R. P. Golden Wax...................... $45 \quad 85$

Wardwell's Kidney Wax.................... .50 I.00

Davis White Wax......................... .50 .90

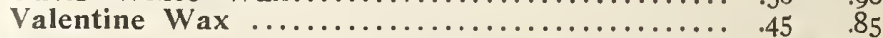

CAULIFLOWER Pkt. $1 / 1 \mathrm{Oz}, \mathrm{Oz}$.

Algiers, large late for outdoor............ \$0.10 \$0.30 \$1.00 Danish Giant ...................... .25 $85 \quad 3.00$

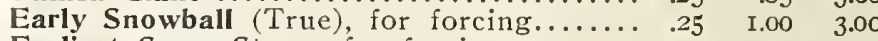

Earliest Snow Storm, for forcing............. .25 1.50 5.00

Half Early Paris, for outdoor us e......... . . I0 $\quad .25 \quad .75$

Michell's Selected Erfurt (True)..........

\section{CORN, Sweet or Sugar-Connecticut Grown}

Varieties that can be planted early in July. Large Packets Ioc. postpaid.

Parcel Post Weight of Corn: I pt. equals I lb.; I qt. equals 2 lbs.

Early Giant Wonder..................... $\$ 0.35$ \$t.

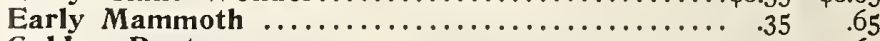

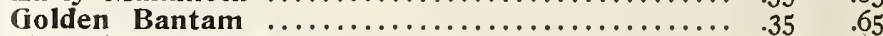

Kendel's Early Giant........................ $.35 \quad .65$

Stowell's Evergreen (Improved Strain).......... $.40 \quad .75$

Also all other varieties

\section{CORN SALAD}

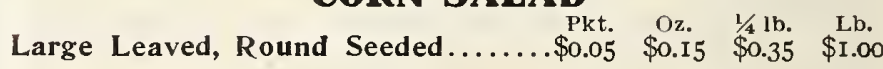

\section{CUCUMBER}

Davis' Perfect ................... :05 $20 \quad .60 \quad 2.00$

Cool and Crisp.....................

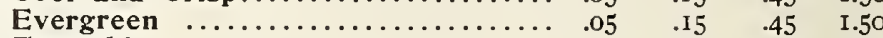

Emerald $\ldots \ldots \ldots \ldots \ldots \ldots \ldots \ldots \ldots \ldots, 0.05 \quad .15 \quad .45 \quad 1.50$

Japanese Climbing $\ldots \ldots \ldots \ldots \ldots \ldots, \quad .05 \quad$. I5 $\quad .45 \quad 1.50$

Jersey Pickle or Green Prolific....... .05

Long Green Turkey (Improved)....

$\begin{array}{llllll}\text { Small Gherkin or Burr................. } & .05 & .20 & .60 & \\ \text { White=Spined (Arlington Strain).... } & .10 & .20 & .60 & 2.00\end{array}$

$\begin{array}{llllll}\text { White=Spined (Improved Strain) . . . } & .05 & .15 & .45 & \text { I.50 }\end{array}$

\section{ENGLISH CUCUMBERS}

These are ideal for growing outdoors as well as under glass. They produce enormous fruits, generally 18 to 24 inches long and 3 inches in diameter.

Lockie's Perfection, Sion House, Telegraph, Tender and True. Each per packet of 12 seeds, 25c.; $\$ 2.00$ per 100 seeds.

CARROTS

Chantenay Half Lon

Danvers Half Long.

Early Scarlet Horn.

Guerande or Oxhart.

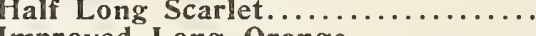

mproved Long Orange..............

Rubicon Half

White Belgian

ENDIVE

Broad Leaved Batavian (Escarolle)..

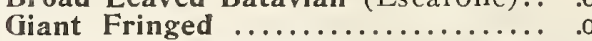

Improved Green Curled.............. .5

\section{KALE}

Dwarf Green Curled $\ldots \ldots \ldots \ldots \ldots \ldots \ldots, \quad .05 \quad .20 \quad .65 \quad 2.50$

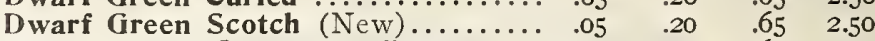
$\begin{array}{llllll}\text { New Imperial Long Standing........ } & .05 & .20 & .65 & 2.50\end{array}$ 


\section{LETTUCE}

Pkt. $1 / 2 \mathrm{Oz}, \mathrm{Oz} ; 1 / 4 \mathrm{Lb} \quad \mathrm{Lb}$

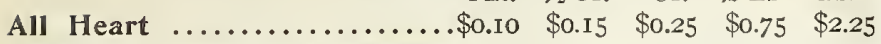
All=Right, Spring and Autumn. $\begin{array}{llllll}\text {.10 } & \text {.I5 } & .25 & .75 & 2.50\end{array}$ Davey's Improved Big Boston. .10 $\quad .20 \quad .40 \quad 1.25$ Dutch Butter, Private Stock... $\begin{array}{llllll}\text { Kingsholm Cos or Romaine... } & .05 & .15 & .25 & .75\end{array}$ $\begin{array}{lllll}\text { Mammoth Salamander (True). } & .05 & \text {.IO } & .20 & .50\end{array}$ Silesian, loose leaved ........ . .05 $\quad .10 \quad .20 \quad .60$

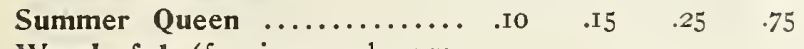
Wonderful (forcing and summer use) ................. .05 . . 20 .50

For other Varieties see our General Seed Book

\section{PARSLEY}

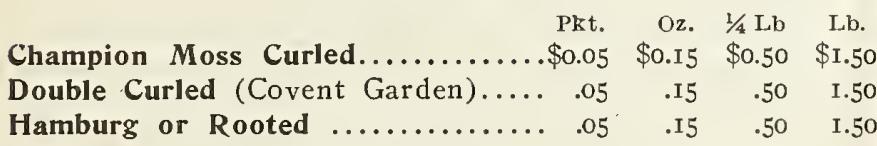

\section{PEAS}

Large Packets of all varieties Ioc. postpaid.

Parcel Post Weight of Peas: I pt. equals I 1b.; I qt. equals 2 lbs.

Alaska (Extra Early) ............. Pt. 4 Qts American Wonder ...................... $\quad .35$

Bliss, Abundance (Medium Early)....... .30

Dandy (Extra Early), Michell's............30

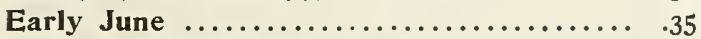

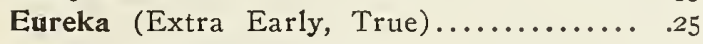

Heroine (Medium Early) ...............30

McLean's Little Gem (Extra Early)....... .30

Long Island Mammoth (Medium).........30

Michell's Special Extra Early............ .30

Nott's Excelsior (Improved Strain)...... .30

Tellephone (Late) ..................35

Qt.
$\$ 0.6$
.65
.6
.65
.50
.60
.60
.60
.60

For other Varieties see our General Seed Book

\section{RADISH}

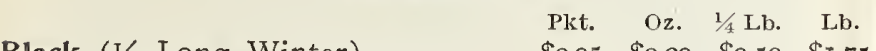

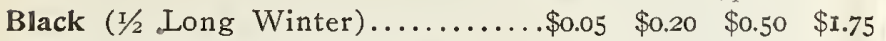
$\begin{array}{llllll}\text { Black Spanish (Long Winter)..... } & .05 & .20 & .50 & \text { I.75 }\end{array}$ $\begin{array}{llllll}\text { Black Spanish (Round Winter)..... } & .05 & .20 & .50 & \text { I.75 }\end{array}$ Cardinal Globe (Improved Strain)... $\begin{array}{lllll}\text { Celestial or White Chinese (Winter). } & .05 & .20 & .50 & \text { I.75 }\end{array}$ $\begin{array}{llllll}\text { China.Rose (Winter) } \ldots \ldots \ldots \ldots \ldots \ldots & .05 & .20 & .50 & \text { I.75 }\end{array}$ Crimson Giant (New) ............... .05 .I5 $\quad .50 \quad$ I.75 French Breakfast ................... .05 $.20 \quad .602 .00$ Icicle (Improved Strain)........... .I0 $\quad .25 \quad .75 \quad 2.50$ Long Scarlet Short Top............ $.05 \quad .20 \quad .60 \quad 2.00$ $\begin{array}{lllll}\text { White Box (Felton's Private Stock). } & .05 & .20 & .60 & 2.00\end{array}$ $\begin{array}{llllll}\text { White Strasburg ( } 1 / 2 \text { Long) ........ } & .05 & .20 & .60 & 2.00\end{array}$

\section{SPINACH}

$\begin{array}{llll}1 / 4 \mathrm{Lb} & \mathrm{Lb} .\end{array}$

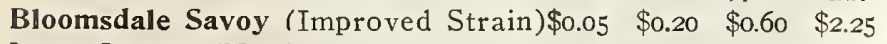
Long Season (New) ................ .0 $\quad .20 \quad .60 \quad 2.25$ New Zealand $\ldots \ldots \ldots \ldots \ldots \ldots \ldots \ldots \ldots .05 \quad .20 \quad .60 \quad 2.25$

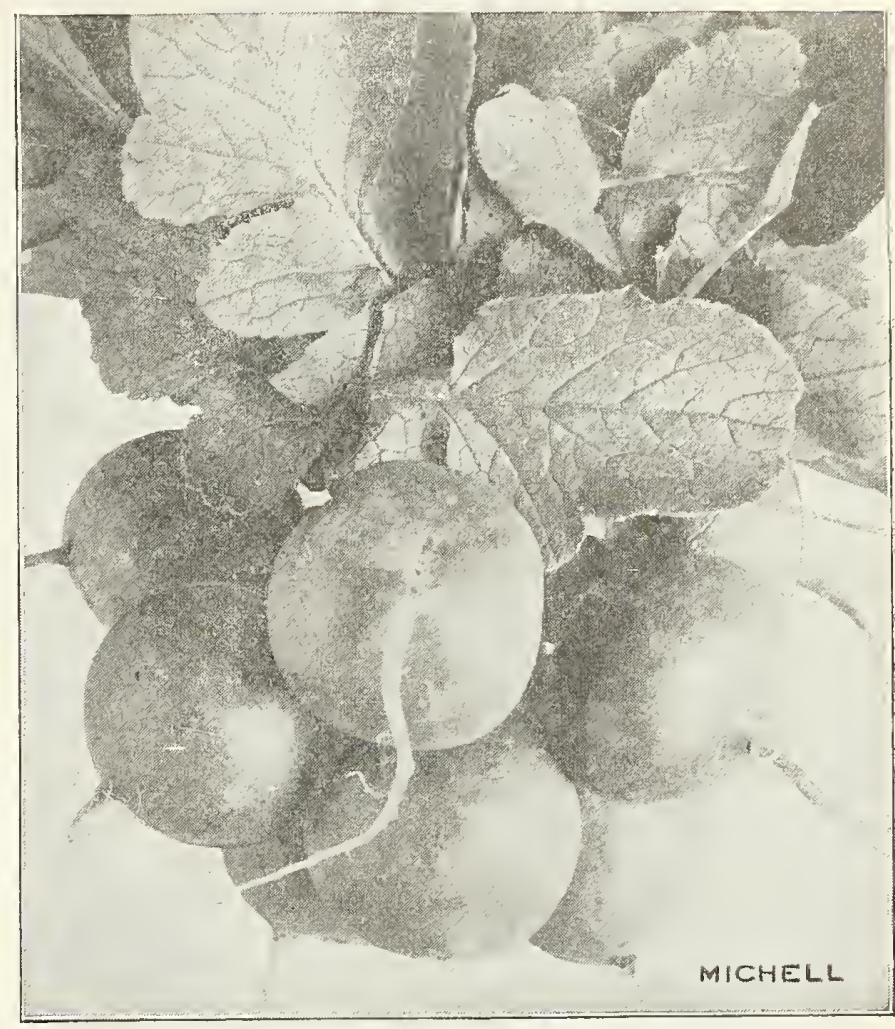

Michell's (Improved Strain) Cardinal Globe Radish.

\section{TOMATOES-Adapted for Forcing}

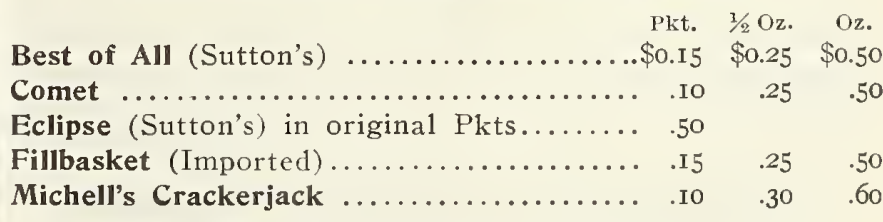

\section{TURNIP AND RUTA BAGA}

Pkt. O2. 1/4 Lb. Lb.

Cow Horn .................... \$0.05 \$0.20 $\$ 0.60 \quad \$ 2.25$

$\begin{array}{llllll}\text { Early Purple Top, Flat.............. } & .05 & .20 & .60 & 2.25\end{array}$

White Globe (Private Stock)....... . . I0 $\quad .30 \quad 75 \quad 2.50$

$\begin{array}{llllll}\text { Purple Top White Globe........... } & .05 & .25 & .65 & 2.25\end{array}$

Ruta Baga, Yellow Purple Top.....

$\begin{array}{llllll}\text { Ruta Baga, Private Stock Globe.... } & \text {. Io } & .25 & .75 & 2.75\end{array}$

$\begin{array}{lllll}\text { White Flat Dutch, Strap Leaved.... } & .05 & .20 & .60 & 2.25\end{array}$

Yellow Aberdeen, Flat ............... $.05 \quad .20 \quad .60 \quad 2.25$

$\begin{array}{llllll}\text { Yellow Gilobe or Amber ........... } & .05 & .20 & .60 & 2.25\end{array}$

\section{MICHELL'S SUPERIOR MUSHROOM SPAWN} Brandywine Pure Culture Spawn

I brick, 35c.; $\$$ I.50 for 5 bricks; Io bricks, $\$ 2.75 ; \$ 6.50$ per 25 bricks; 50 bricks, \$12.50.

\section{LAMBERT'S PURE CULTURE SPAWN}

I brick, 30c.; $\$ 1.25$ for 5 bricks; 10 bricks, $\$ 2.30 ; \$ 5.60$ per 25 bricks; 50 bricks, \$10.50. 


\section{MIXTURES FOR LAWNS}

Michell's Clover Lawn Grass Seed Mixture. 30 lbs. per bu. For sandy soils lacking humus or for seashore lawns-per pint, 30c.; 50c. per qt.; 2 qts., 90c.; 4 qts., \$I.75; per peck, $\$ 3.00$; per bu., \$II.50.

Michell's Top Notch. 25 lbs. per bu. The finest Lawn Mixture in existence. It is not put up or sold in less quantity than I peck. Prices: $\$ 2.00$ per peck; $\$ 7.50$ per bu. of 25 lbs.; 2 bu., $\$$ I $4.50 ; \$ 35.00$ per 5 bu.; Ioo lb. lots and over 28c. per $1 \mathrm{~b}$.

Michell's Gireen Velvet. 20 lbs. per bu. Produces a perfect Lawn in 4 to 5 weeks time. Sow 4 bu. per acre. Prices: 30c. per qt.; 4 qts., 85c.; \$1.25 per peck; per bu., $\$ 5.00 ;$ IOo lb. lots and over, 24c. per lb.

Michell's Evergreen. 20 lbs. per bu. The standard Lawn Mixture in the U. S. for the past twenty-five years. Always satisfactory. Sow 4 bu. per acre. Prices: 25c. per qt.; 4 qts., 75c.; \$I.00 per peck; bu. (20 lbs.), \$4.00; IO0 Ib. lots and over, $19^{1} / 2 \mathrm{c}$. per $1 \mathrm{~b}$.

Michell's Shaded Lawn Grass. Will produce perfect swards in the most densely shaded places. Prices: 30c. per qt.; 85 c. per 4 qts.; peck, $\$ \mathrm{I} .50 ; \$ 6.00$ per bu. (20 lbs.); I00 lb. lots and over, $28 \mathrm{r} / 2 \mathrm{c}$ per $1 \mathrm{~b}$.

Fairmount Park Lawn Seed. Sow 4 bu. to the acre. Prices : per qt., 20c.; 6oc. for 4 qts.; 85c. per peck; per bushel of I5 Ibs., $\$ 3.00$; I00 lb. lots and over, I9c. per $1 \mathrm{~b}$.

Michell's Seashore Formula Grass Seed. Contains such grasses as thrive in salt air regions. Sow 4 bu. to the acre. Prices: per qt., 25c.; 85c. for 4 qts.; $\$ 1.25$ per peck; per bu. of $20 \mathrm{lbs} ., \$ 5.00$; Ioo $\mathrm{lb}$. lots and over, $24 \mathrm{c}$. per $1 \mathrm{~b}$.

Michell's Terrace or Embankment Grass Seed. Sow 4 bu. to the acre. Prices: per qt., 25c.; 75c. for 4 qts.; $\$ 1.25$ per peck; per bu. of 20 lbs., $\$ 5.00$; IOo $1 \mathrm{~b}$. lots and over, $24 \mathrm{c}$. per lb.

Southern States Lawn Grass Seed. Made up especially for dry, hot localities, especially suited to the Southern States. I5 lbs. per bu. Prices: 20c. per qt.; 6oc. for 4 qts.; peck, $\$ 1.00 ; \$ 3.50$ per bu.; Ioo lb. lots and over, 2 Ic. per lb.

Special Sod Grass Seed. Producing a heavy sod in a short time. I5 lbs. per bu. Prices: 25c. per qt.; $75 \mathrm{c}$. for 4 qts.; peck, \$I.00; $\$ 4.00$ per bu.; I0o $1 \mathrm{~b}$. lots and over, 25c. per $1 \mathrm{~b}$.

Woodlands Lawn Mixture. 20 lbs. per bu. For sowing in dense shade among trees, in woods, etc. \$I.oo per peck; per bu., $\$ 4.00 ; \$ 19.50$ for 5 bu.; Ioo $1 \mathrm{~b}$. lots and over, I9 $1 / 2 \mathrm{c}$. per $1 \mathrm{~b}$.

\section{MIXTURES FOR PLEASURE GROUNDS Michell's Fair Greens Mixture Goll Course}

Composed of short-growing, deep-rooted varieties, resisting plenty of wear. Golf courses, to retain their permanency, should receive additional sowings during the season. Sow 6 bu. per acre. Prices: per qt., 25c.; 75c. for 4 qts.; I peck, $\$$ I.25; I bu. (20 lbs.), $\$ 5.00$; Ioo lb. lots and over, $233 / 4$ c. per $1 \mathrm{~b}$.

\section{GRASSSES IN SEPARATE VARIETIES}

\section{All Strictly Recleaned and Carefully Tested for Purity and Germination}

\section{Prices Subject to Market Changes}

We handle the best recleaned grass seeds in separate varieties. Some persons like to do their own mixing or prefer to sow only one kind of grass; we make no charge for mix= ing.

Lbs per bush

35 Bermuda Grass Lb. Bush. $100 \mathrm{Lbs}$

4. Blue Grass (Kentucky). Extra fancy 3

to 5 bu. per acre (\$I.25 per peck) .... 4 Blue Grass (Canadian). 3 to 5 bu. per acre $.30 \quad 3.00 \quad 20.00$ Creeping Bent. 4 bu. per acre....... Price on application Crested Dogstail. $3^{\mathrm{T} / 2}$ to 4 bu. per acre. $.50 \quad 9.00 \quad 40.00$ 4 English Rye (Pacey's Fancy Short Seed-

ed). Fine for Lawns. 3 bu. per acre. 20 3.25 I3.00 Herd or Red Top. Unhulled, 4 to 5 bu.

\section{MIXTURES FOR PLEASURE GROUNDS (Continued) \\ Michell's Putting Greens Mixture}

A quick-growing mixture of short, thin-bladed grasses, over which the ball can roll without resistance. We do not recommend less than I bu. of $25 \mathrm{lbs}$, to a green 75 feet square. Prices: I qt., 30c.; 4 qts., \$I.15; I peck, $\$ 2.25$; I bu. (25 lbs.), $\$ 9.00$; I00 1b. lots and over, 35c. per lb.

Teeing Grounds Mixture. Used on golf courses or in places where a tough, resisting turf is wanted (20 lbs. per bu.). 25c. per qt.; 4 qts., 65c.; \$1.00 per peck; per bu., $\$ 4.00$.

har Tennis Grass Seed. Tennis courts need grasses of a , of fine leat and close, compact growth. Our (20 lbs. per bu.). Prices: I qt., 25c.; 75c. for 4 qts.; per peck, $\$ \mathrm{I} .25 ; \$ 4.50$ per bu. ; Ioo $1 \mathrm{~b}$. lots and over, $2 \mathrm{I} 1 / 4 \mathrm{c}$. per $1 \mathrm{~b}$.

\section{MIXTURES FOR MISCELLANEOUS PURPOSES}

Michell's Permanent Pasture Grass Seed. In the past few years ideas of what was the best way to establish a permanent grazing sod have undergone many changes. The old prevalent method of sowing timothy and clover has been found not only costly, but too short-lived to answer the purpose. The old custom has given way to the new, which is the sowing of a mixture of permanent grasses. Michell's Permanent Pasture Grass Seed is composed of about Io of the best growing and most nutritious grasses and clovers for stock feeding or grazing. One sowing will last many years, although we advise additional sowing each autumn, just previous to which a light harrowing. is recommended to give the grass a quick hold. Sow 3 to 4 bu. per acre on new land or 2 bu. on established pastures (I5 1bs. per bu.). Prices : per qt., 20c. ; 4 qts., 6oc.; per peck, $\$ 1.00$; per bu. (I5 lbs.), $\$ 3.50$; Ioo lb. lots and over, I6c. per $1 \mathrm{~b}$ Michell's Permanent Hayfield Grass Seed. While timothy is still extensively sown for this purpose, this mixture is gradually being adopted by the progressive farmer. Its main advantages are that certain grasses in this mixture will grow better in varying conditions of soil, thus giving a full crop of hay on land that otherwise might produce but a half crop of timothy and clover. Our formula is the outcome of thorough trials in every kind of soil. Sow 3 to 4 bu. per acre on new lands or 2 bu. on established fields (I5 lbs. per bu.). Prices: per qt., 20c.; 4 qts., 6oc.; per peck, $\$ 1.00 ;$ per bu. (I5 lbs.), $\$ 3.50 ;$ I00 $1 \mathrm{~b}$. lots and over, I6 $1 / 2 \mathrm{c}$. .

Michell's Poultry Yard Grass Seed. Chickens love grass and should be placed where they can get it as much as possile. We put plenty of clover seed in this mixture, as it is very nutritious, and the fowls relish it ( 15 lbs. per bu.). 20c. per qt.; 4 qts., 6oc.; 85c. per peck; bu., $\$ 3.00$

\section{WHITE CLOVER}

Choice recleaned for sowing on lawns, pastures, etc. Sow io to 12 lbs. per acre (6o lbs. per bu.). Per $1 / 4$ lb., 20c.; 60c. per lb.; 5 lbs., $\$ 2.80 ; \$ 5.50$ for Io lbs.; per bu., $\$ 32.40$; per 100 lbs., $\$ 54.00$.
I2 Hard Fescue. $30 \mathrm{lbs}$. per acre........ Price on application Lbs. per bush. I8 Italian Rye. 50 1bs. per acre........ \$0.20 \$3.00 \$I3.00 22 Meadow Fescue. English Blue Grass.. $.25 \quad 4.00 \quad$ I6.50 I2 Orchard. 40 lbs. per acre...........4 $40 \quad 4.50 \quad 33.00$ 14 Red or Creeping Fescue...............6 $7.50 \quad 50.00$ 32 Red Top. Recleaned .................30 $7.75 \quad 22.00$ I4 Rhode Island Bent. 40 lbs. per acre... $75 \quad 7.25 \quad 65.00$

I2 Sheep's Fescue. 40 lbs. per acre.....Price on application

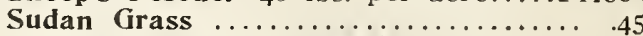

Sweet Vernal (Perennial). 3 lbs. per

acre with other grass.............. Price on application Sweet Vernal (Annual). 3 lbs, per acre with other grass.................. Price on application Io Tall Meadow Oat (French Rye Grass).. $35 \quad 3.00 \quad 25.00$ 45 Timothy Seed. $1 / 2$ bu. per acre alone.. .20

Wood Meadow. $30 \mathrm{lbs}$. per acre..... Price on application 


\section{Michell's High Grade Farm Seeds}

\section{PRICES SUBJECT TO MARKET CHANGES}

Alfalfa (Medicago Sativa). Sow $1 / 2$ bu., 30 lbs. per acre during May, August or September. Price, per 1b., 25c.

Buckwheat. Sow I bu. per acre during June and July. Japanese and Silver Hull. Each, I5c. per qt.

Barley, Beardless. Sow $1 / 2$ to 2 bu. per acre from May 15 th to July Ist. I5c. per qt.; price for larger quantity on application.

Beans, Soja. Sow $I \frac{1}{2}$ bu. per acre during May. Mammoth yellow; Early Hollybrook, Ito San, Wilson. Price on application.

Broom Corn. Early Evergreen. Sow io lbs. per acre during May. I5c per qt.

Clover, Alsike. Sow ro lbs. per acre during March, April or August.

" Bokhara or Sweet. Sow 15 lbs. per acre during April or August.

" Crimson. Sow 20 lbs. per acre during July or August. “ Mammoth Red. Sow 20 lbs, per acre during March April or August.

" Red Medium. Sow 20 lbs. per acre during March, April or August.

White Dutch. Sow Io 1bs. per acre. Ioc. per oz.; $1 / 4$ 1b., 2oc.; 6oc. per 1b.; 5 lbs., $\$ 2.80 ; \$ 5.50$ for Io 1 bs. Price for larger quantity on application.

Cotton Seed. Grown principally as an ornamental crop in this latitude. 25c. per 1b.; 5 lbs., $\$$ I.00.

Canada Field Peas. Sow $I^{1 / 2}$ bu. per acre during April, with I bushel of oats. This makes splendid green feed. Price on application.

Cow Peas. Sow from May to July ist 2 bu. per acre broadcast, or I bu. per acre in drills. Black, Black Eye, Whippoorwill Mixed. Prices on application.

Flax. Sow I bu. per acre during May and'June. Lb., Ioc.

Kaffir Corn. Sow in June and July. Io lbs, per acre. Lb., IOC.

Millet. A splendid emergency hay crop; can be harvested in 60 days. Sow during June and July; I bu. per acre. Hungarian and Golden. Lb., I5c. Japanese; sow 12 lbs. per acre. Ioc. per 1b. Pearl; sow Io 1bs. per acre. Lb, I5c.

Oats. Sow from April until June; 3 bu. per acre. Swedish or Washington, Canadian Cluster, Tartar King, Storm King. Price on application.

Rye, Sow I I/2 bu. per acre broadcast during April, May, October and November, spring and winter; choice strains of both.

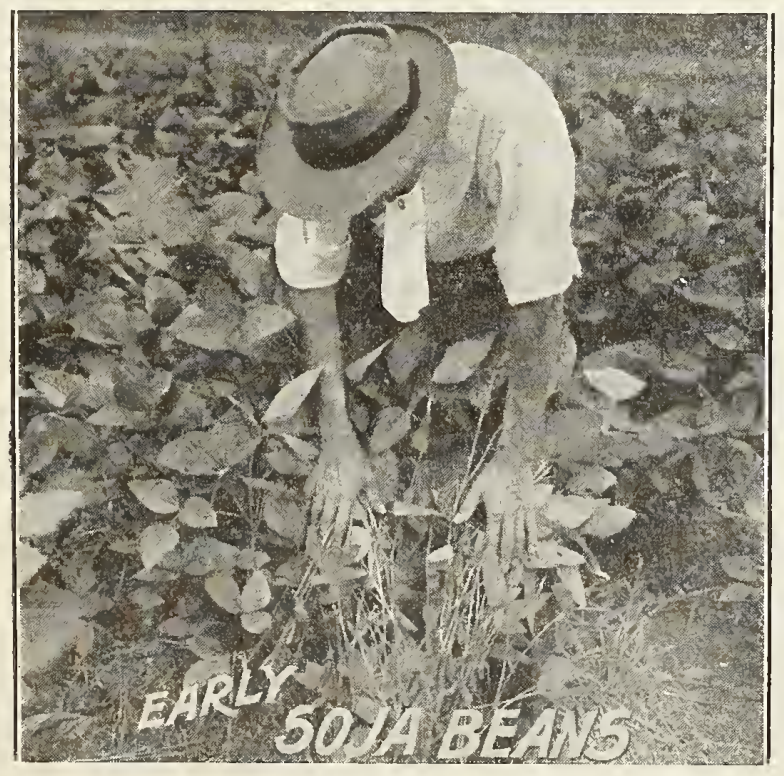

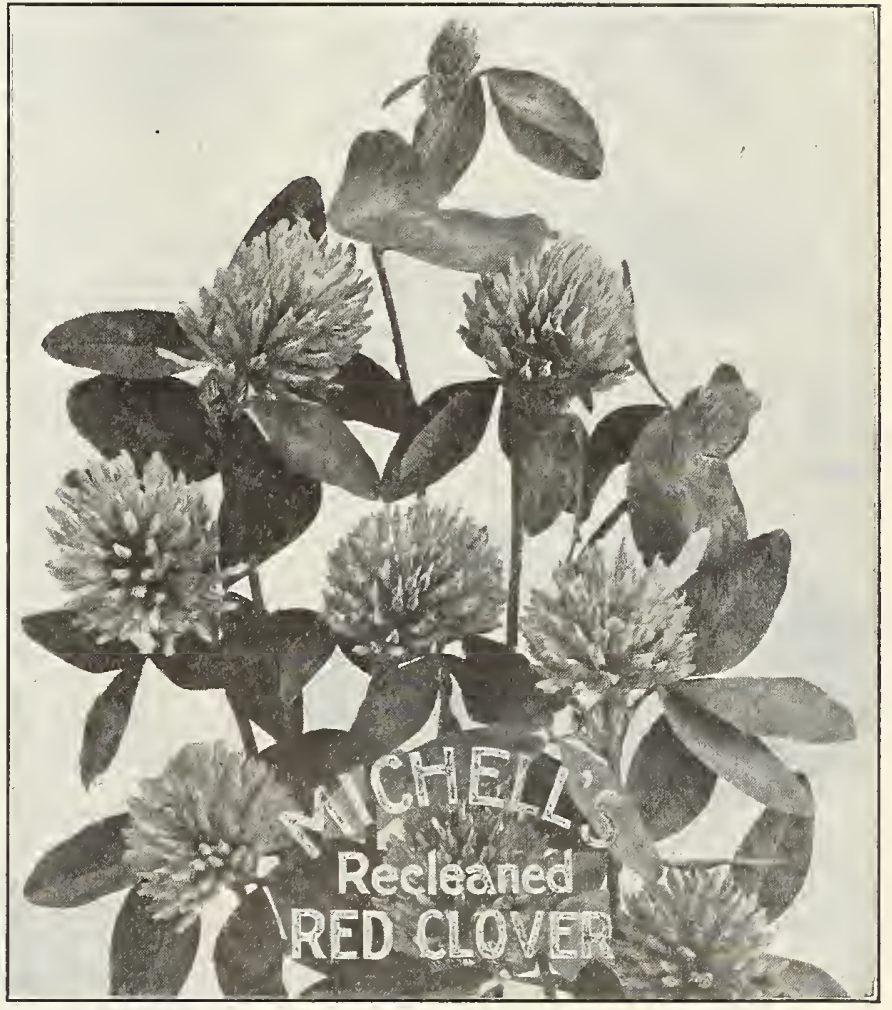

Our Strains of Red Clover in both Mammoth and Medium types are anusually fine

Rape. Dwarf Essex. Sow 6 lbs. per acre broadcast, or in drills at intervals from April ist to October Ist. 20c. per 1b.

Sorghum or Sugar Cane. Early Amber. Sow 25 lbs. per acre in drills during May or June. I5c. per $1 \mathrm{~b}$.

Speltz or Emmer. Sow during April and May; 2 bu. per acre. IOc. lb.

Sudan Grass. Similar to millet. Sow 16 to 24 lbs. per acre broadcast during April, May and June. Price on application.

Sunflower. Mammoth Russian; splendid poultry food. Sow Io qts. per acre in drills. ' $12 c$. qt.; 40c. for 4 qts.; peck, 65c.; bushel (25 1bs.), \$2.50.

Timothy. Sow $1 / 2$ bu. per acre during April, August or September. I5c. $1 \mathrm{~b}$.

Teosinte. A splendid forage plant for dry sandy soils. Sow in May and June; 5 to $6 \mathrm{lbs}$. per acre. Price on application.

Vetch. For green feed, green manure and cover crops. Sow I bu. per acre broadcast. Winter (Vicia Villosa). Spring (Vicia Sativa).

Wheat. Sow $1 \frac{1}{2}$ bu. per acre in drills; Spring, Saskatchewan Fife. Winter varieties ready after September 15th. Prices on application.

ABOUT PRICES-For larger quantities than mentioned, these will be quoted on application. 
MICHELL'S

\section{LAWN SPRINKLERS}

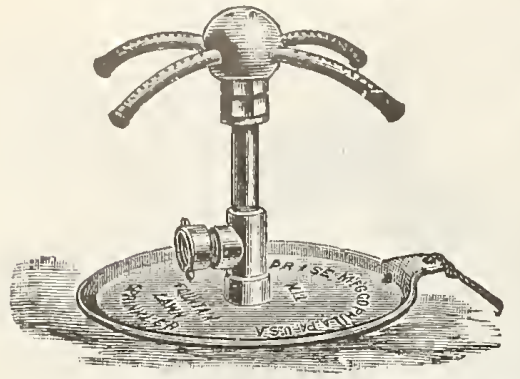

Enterprise. No. I. See cut..I4lbs, \$4.50 Ring. Large, see cut.......... I lb. I.00 Ring or Fountain. Small ....3/4 lb. $\quad .75$ Hotchkiss. No. 5 . IO $1 / 2$ in. high. 4 lbs. I.25 Pluvius. II in. high........ $3^{\mathrm{I} / 4}$ lbs. I.50

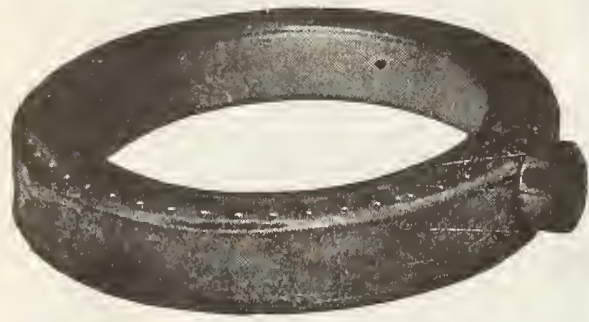

Weight Price

Universal. No. 65. Io in. high. $4^{\mathrm{T}} / 4 \mathrm{lbs}$. $\$ 2.00$ Eureka. No. 55. Io in. high ..3 lbs. I.50 A etna. 24 in. high........6. $61 / 4$ lbs. 2.25

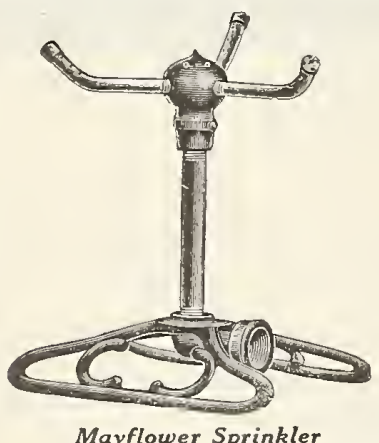

Weight Price Mayflower. $9^{\mathrm{x} / 2}$ in. high....3 $1 / 2 \mathrm{lbs}$. $\$ \mathrm{I} .50$ Preston. $5^{\mathrm{T} / 2}$ in. high....... $31 / 2$ lbs. I.50 Waterwitch. $83 / 4$ in. high..... I lbs. .50 C. B. G. For golf links.......3/4 lb. .25

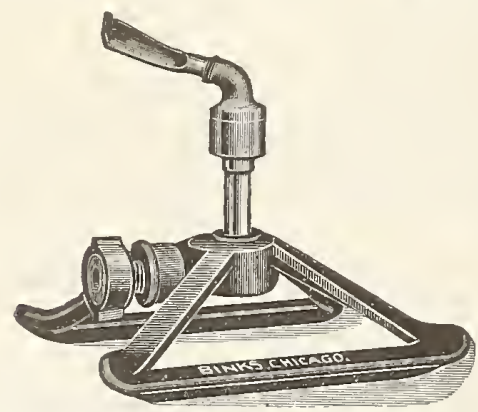

Binks Rainfall Sprinkler (see illustration above). For large lawns, putting greens, etc. Covers an area $40 \mathrm{ft}$. in diameter, according to pressure. \$1.50 each.

\section{SEASONABLE SUNDRIES}

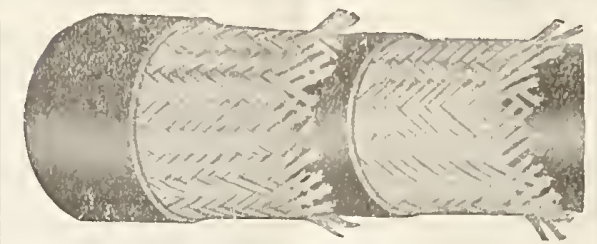

Showing the interior of Michell's Special Hose

\section{RUBBER HOSE}

Michell's Rubber Hose is noted for its reliability in every way. Our very large sales enable us to deal direct with the factory, where we obtain lowest prices, which we in turn give our customers the benefit of.

Wt. per foot Per foot

*Michell's Special, 3/4-inch..5 oz. \$0.181/2

*Michell's Special, $1 / 2$-inch..4 oz.

*Electric, $3 / 4$-inch ......... oz.

.17

*Electric, $1 / 2$-inch $\ldots . . .4 .40 \mathrm{oz}$

*Revero, $3 / 4$-inch $\ldots \ldots \ldots .5 \mathrm{oz}$.

*Revero, $1 / 2$-inch ........4 oz.

Empire Red (corrugated),

$3 / 4$-inch .............. oz.

Spray Pump Hose, $3 / 8$-inch..3 oz

P. S.-Brands marked * come in reels of 500 feet and sections in any length to that number of feet may be had.

25 and 50-foot sections of hose coupled free. Smaller sections coupled at the rate of 3oc. per pair for couplings.

Hose Washers. For inside and outside of couplings. 8c. doz.; $1 / 4$ lb., $30 \mathrm{c}$.

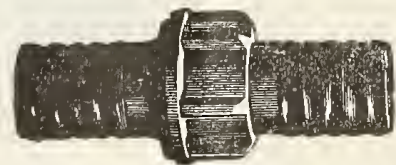

\section{BRASS HOSE COUPLINGS}

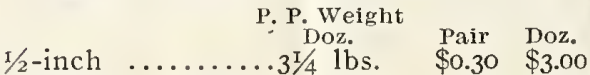

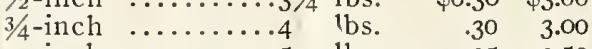

$$
\begin{aligned}
& \text { I-inch } \ldots \ldots \ldots \ldots .5 \text { lbs. } \quad .35 \quad 3.50
\end{aligned}
$$

\section{ACME HOSE COUPLINGS}

For quickly connecting and detaching hose.

No. 3 part, for attaching to spigot, I8c. each; doz., \$2.00. Weight, per doz., 3 lbs.

No. 4 part, for attaching to hose, 3oc. each; doz., \$3.50. Weight, doz., 3 lbs.

Couplings complete, consisting of one No. 3 and one No. 4 part, $47 \mathrm{c}$. each; per doz., \$5.50. Weight, per doz., 6 lbs.

\section{SNAP HOSE COUPLING}

Snap Couplings are entirely new and novel. They couple hose instantly, work on a spring, and are water-tight. 30c. pair; doz. pairs, \$3.25. (Washers, 20c. doz).

Parcel Post Weight, per doz., 21/2 lbs.

\section{SNAP COUPLING PARTS}

No. 2. Male. I2c. each; per doz., \$I.35. Parcel Post Weight, per doz., I $1 / 4$ lbs. No, I. Female. 20c. each; per doz., \$2.00. Parcel Post Weight, per doz., I $1 / 4$ lbs.

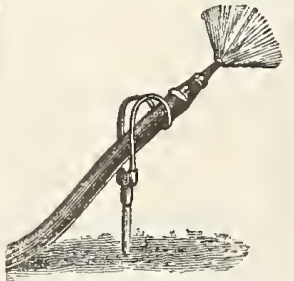

\section{NOZZLE HOL.DERS}

For sticking in the ground while on e continues with other work. Made of galvanized heavy wire. Price, 25c. each.

P. P. Wt., 8 ozs.

\section{HOSE MENDERS}

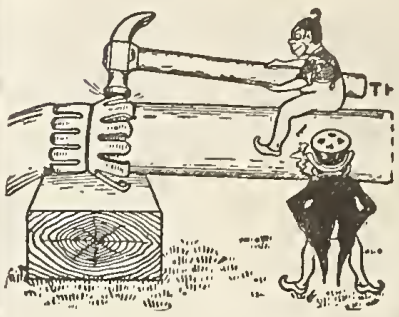

P erfect (s e e c ut). $M$ a d e entirely of brass, with swivel motion-no band $\mathrm{re}$ quired.

For $3 / 4$ in hose, I2c each ; doz. $\$ \mathrm{I} .20$.

Parcel Post Weight, per doz., I $3 / 4$ lb. P. P. Welght Do\% Each Doz

Cooper's, $3 / 4-$ in ........ I I $/ 4$ lbs. \$0.Io $\$ I .00$ Cooper's, $5 / 8$-in......... I lb. .IO I.00 Cooper's, $1 / 2$-in........ I lb. .IO I.00 Jones, $3 / 4$-in. (iron...).2 $2^{\mathrm{T}} / 4$ lbs. $.06 \quad .60$ Hudson's, $3 / 4$-in. (brass). $1 / 21 \mathrm{~b}$. $.08 \quad .85$ Hudson's, 1/2-in. (brass) 6 ozs. $\quad .07 \quad .75$ Republic, $3 / 4$-in. (screw sleeve) .I5 I.50 Hudson's Outfit. For $3 / 4$-inch hose.

Furnishes a complete outfit, consisting of 6 menders or connections, 18 bands or fasteners, and a pair of pliers for fastening bands. Price, 85c. each. Parcel Post Weight, . I lb.

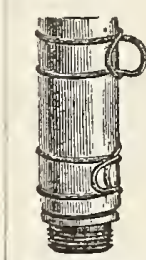

Caldwell Band as applied
to Hose

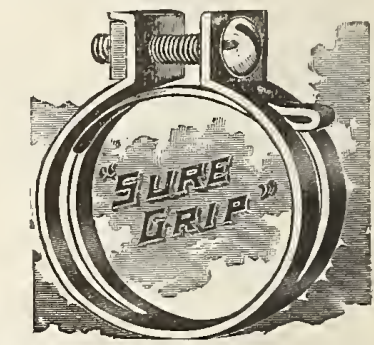

HOSE BANDS

For fastening couplings and menders. Caldwell's 8. For 3-ply hose.\$0.40 \$2.50 Caldwell's 6. For 4-ply hose. .402 .50 Parcel Post Wt., doz., I/4 1b.; I00, 21/4 lbs. Hudson's. $3 / 4$-inch .......... \$0.I8 \$I.25 Hudson's. $1 / 2$-inch ............. . I8 1.25 Parcel Post Wt., doz., I/4 lb.; I00, 21/4 lbs. Sure Grip. 3/4-in., 5c. each; per doz., 5oc. Parcel Post Wt., doz., I 1b.; I0o, 91/2 lbs.

\section{HOSE REELS}

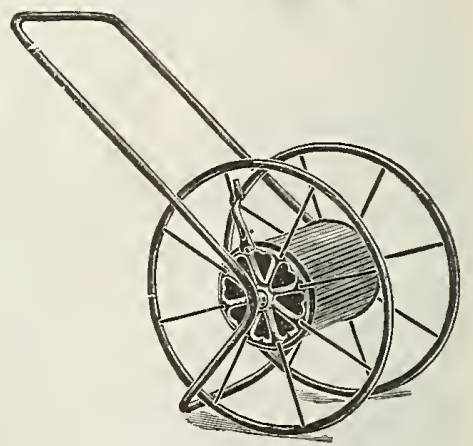

Wirt's All Iron Hose Reel WIR'T'S (All Iron)

Reels are not mailable.

Io........... I00 feet.........\$4.00 $20 . \therefore \ldots \ldots \ldots$. I50 feet......... 4.50

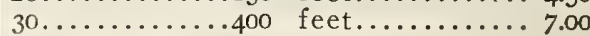




\section{MICHELL'S}

HOSE FITTINGS

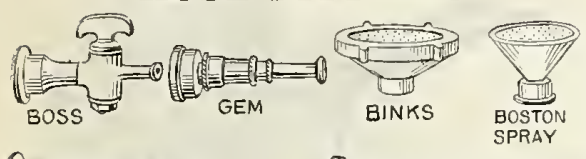

車

GREENHOUSE HOSE NOZZLE
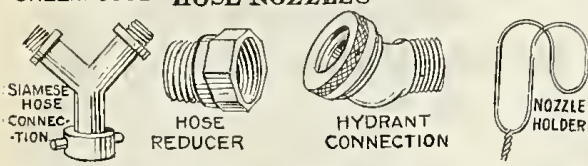

Siamese. This permits one lead of hose to be diverted in two directions. Additional three-way connections can be used according to the water pressure. It is specially a Parcel Post Weight, $1 \mathrm{lb}$.

Hydrant Attachments. To be used for at-

taching hose to smooth faucets. Parcel Post Weight, 1/2 lb.

Boyd Style ........................ Parcel Post Weight, $1 / 2 \mathrm{lb}$. to fit regular $3 / 4$-inch hose. All brass.

Each ....................45e. Parcel Post Weight, 11/2 lbs.

\section{HOSE NOZZLES} Plain Stream. 4 inch ..... P. P. W.

Boston. Light 6 inch $\ldots \ldots$ ozper or coarse) ........... $1 / 2 \mathrm{lb}$. Price
$\$ 0.75$
1.00

Heavy Brass $\ldots \ldots \ldots 1^{1 / 2}$ lb. $\$ 0.85$

Binks. Made of aluminum, with brass face; equipped with interchangeable sprays, ble without wetting the hands. Positively the best and most indestructible nozzle made. $\$ 2.75$ each; worth twice the price. Parcel Post Weight, 11/t lbs.

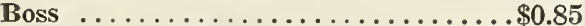

Gem ................... .60

Greenhouse or Rainbow. An all-brass device with an adjustable arrangement, which regulates in a perfect manner the character of the stream this nozzle will throw. Florists consider it one of the very best on the market today. For 3/4-inch hose. Parcel Post Weight, $1 \mathrm{lb}$. Price, $\$ 2.00$.

WATER CANS (Wotherspoon's)

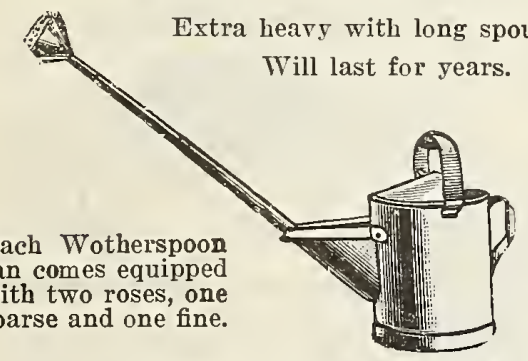

2 quart (equipped with one rose only).$\$ 1.50$

Round Oval

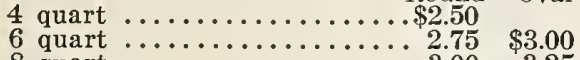

8 quart ................. 3.00

$\$ 3.00$

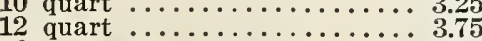

16 quart ................. 4.50

3.50

3.50 ished

4.00 No.

4.75 No. 2

No. 2
No. $21 / 2$
No. 3

4 quart Fern or Low Watering Can. 2.25
Hose Reducer. For reducing 1 -inch pipe

EXTRA ROSES OR SPRAYS

For Wotherspoon Watering Can, either coarse or fine, 60c. each.

Parcel Post Weight, 8 ozs.

ENGLISH WATERING CANS

Made of very heavy tin; carefully enamled inside and out; finished light green.

No. 2,4 qt....\$2.75 No. 3, 6 qt. ...\$3.00 qt... 3.50 No. 5, 10 qt... 4.00

GALVANIZED WATER CANS

Fine for cemetery purposes and other places where a can is desired to last several easons. (Not mailable.)

4 quart.....\$0.85 12 quart ....\$1.65

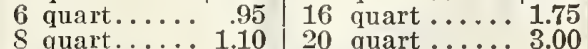

10 quart...... 1.35

\section{LIGHT TIN WATER CANS}

quart, green..............\$0.35 Parcel Post Weight, 1 lb.

quart, green ....

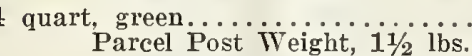

\section{RUBBER APRONS}

For protecting the clothing while watering or doing any work in the garden where your clothes could become soiled. Parcel Post Weight, 2 lbs. Price, \$2.25.

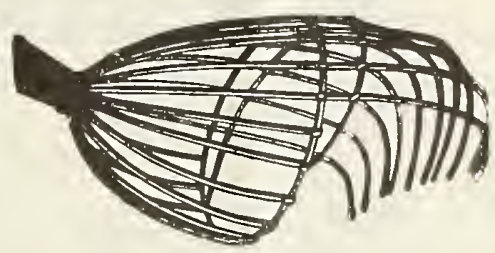

\section{BOSS FRUIT PICKER}

Made substantially of galvanized wire. Can easily be attached to a pole of any Poles for Fruit Pickers.

12 feet .................... \$1.00

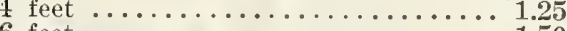

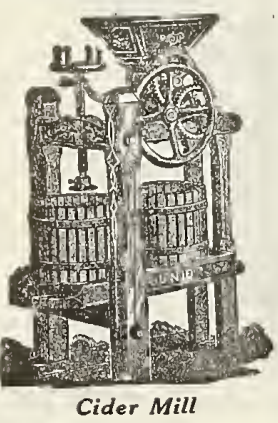

WINE

\section{PRESSES}

M a d e of best

ality wood, care-

\section{GLAZING POINTS}

Peerless. Made of aine with tinned finish: can be used on right or left hand side of sash bar. Three sizes.

No. 1 for single thick No. 2 for single thick No. 21/2 for double thick glass.

Price, 60c. per 1000. Bv mail; 10c. per 1000 extra. Nos. 1 and 2. Michell's Glazing Points. Quite like the Peerless style. No. 2 and $21 / 2,60 \mathrm{c}$. per 1000 . (By mail, 70c.)

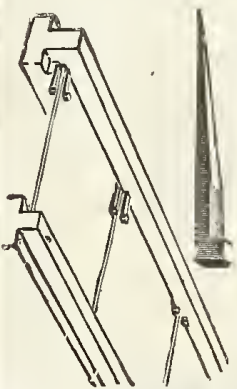

Pincers. For driving Michell's and Peerless Points, 50c. By mail, 55c.

Siebert "Style. M a d e with a prominent head cannot rust: e a sily driven. $5-8,6-8$ and $7-8$ inches long. Zinc, 55c. per lb.; 5 lbs., $\$ 2.60$. 1000 to 1200 in a $\mathrm{lb}$.

Zine Glazing Nails. $50 \mathrm{c}$ per lb.; 5 lbs., $\$ 2.40$.

Siebert's Glazing Points

\section{GLASS CUTTERS}

Single Wheel, steel, each..........\$0.15 6-Wheel, steel, each (see cut)........ .50

Diamond (ebony handle) .............3.00 Diamond (cocoa handle) ..........4.4.00

\section{GLASS CLAMPS}

For supporting broken lights of glass. Per box of $100, \$ 1.75$. Parcel Post weight, 11/4 lbs.

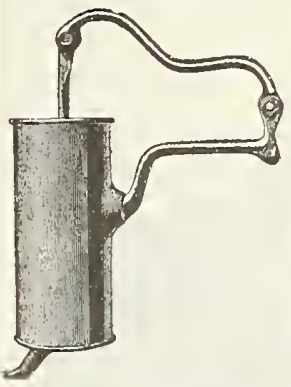

Mastica Machine

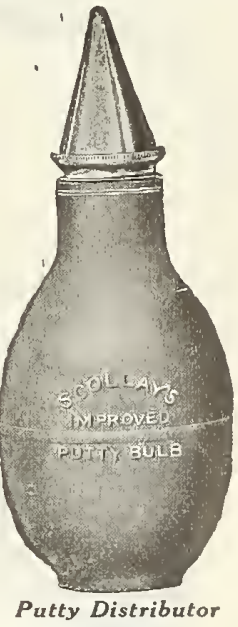

Medium … 122.00 Senior .... 27.50 Little Boss . 12.50

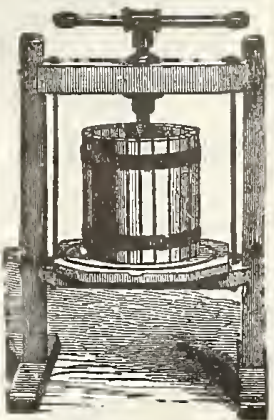

PUTTY DISTRIBUTOR

For distributing putty, mastica, etc.

Price, \$1.25. Parcel Post weight, $1 \mathrm{lb}$. MASTICA

For glazing greenhouses, new or old. $1 / 2$ gallon ....... P. Wt., 8 lbs. $\$ 1.05$ 1 gallon .........P. P. Wt., 15 lbs. 2.00

MASTHCA MACHINE

For distributing mastica, ete. Made of heary zinc. Price, $\$ 2.00$. P. P. Wt., 2 lbs. TWEMLOW'S PUTTY

Superior to putty, more easily applied. 16-lb. can (1 gal.) P. P. Wt., 18 lbs...\$2.50 50 lbs. (5 gals.)................. 7.20 80 lbs. (5 gals.)................... HAMMOND'S GREENHOUSE WHITE A superior white paint. 1 gal., $\$ 3.75$. 


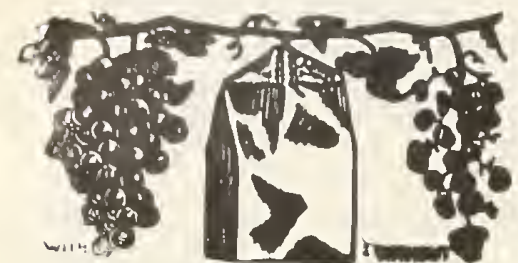

BAGS FOR PROTECTING GRAPES

Grape growers will find after once us ing that these bags are indispensable;
they keep the fruit clean, and free from insects, at the same time allow it to ripen freely. Grapes in bags sometimes keep until very late in the autumn on the vines.

If put on during the period when grapes are forming, they will save many times their cost in the amount of fruit they will rescue from insects, rot, etc. All ready with fasteners to attach.

If desired by mail please add to the prices below as noted.

2 lb. size.... Weight for mail per $100 \quad 100 \quad \$ 1000$ 3 lb. size... $\quad \mathrm{I} / 2 \mathrm{lbs}$. $\quad .60 \quad 5.00$ 4 lb. size... I $1 \frac{1}{2}$ lbs.

\section{HEDGE SHEARS}

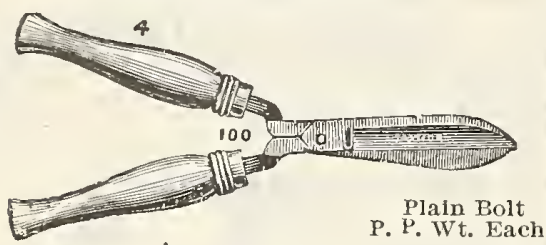

I07- $61 / 2$ inch, Ladies'......4 1bs. \$I.35 $\mathrm{IOI}-8$ " $\quad \ldots \ldots \ldots \ldots \ldots$ lbs. $\quad$ I.80 IOI $9 \quad$ " $9 \quad \ldots \ldots \ldots \ldots \ldots$. IOI-IO

IOI-I2

Handles for Hedge Shears, 3.00 pair.

SIEVES (Any Size Mesh)

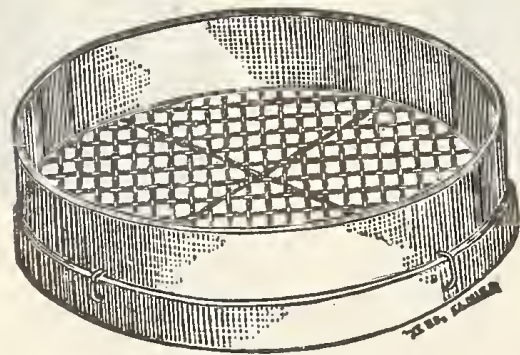

Made extra well.

20-inch Regular wire....6 1bs. I8-inch Regular wire.....6 lbs.

$\$ 1.25$

\section{PAINTED POT LABELS}

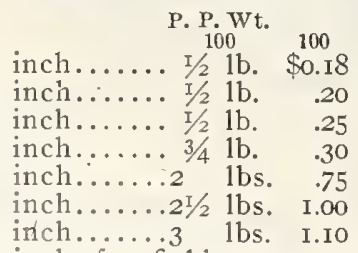

$500 \quad 1000$

$0.70 \$ 1.25$

$\begin{array}{ll}.80 & 1.50 \\ .90 & 1.65\end{array}$

1.00

2.90

3.75

$4.50 \quad 8.25$

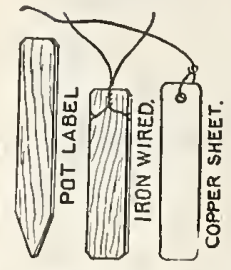

\section{TREE LABELS}

Parcel Post Weight, $1 / 2$ 1b. per 100.

Iron Wired. $100 \quad 1000$ Plain ....\$0.25 \$I.30 Iron Wired.

Painted .. $.25 \quad$ I.55

C o p p e r

Wired. Plain .25 I.50

Copper Wired. Painted...... .30 I.85

Copper Sheet, wired.25c. doz.; 100, \$I.50

Zinc Sheet, wired....25c. doz.; I00, \$1.25

Indelible Marking Pencils.....each, IOc.

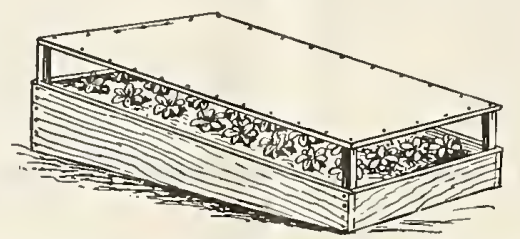

SHADING OR PROTECTING CLOTH

It is admirable for summer use, pro-

tecting plants, etc., from sun and at the ame time allowing ventilation.

Yds. per Price Price
Piece Per Yd. Per Pc. Light. Brown cloth..60 $\begin{array}{ll}\$ 0.20 & \$ 10.80\end{array}$ Medium. " " $\quad .60 \quad .30 \quad$ I5.60 Heavy.

\section{LAWN BORDER SHEARS}

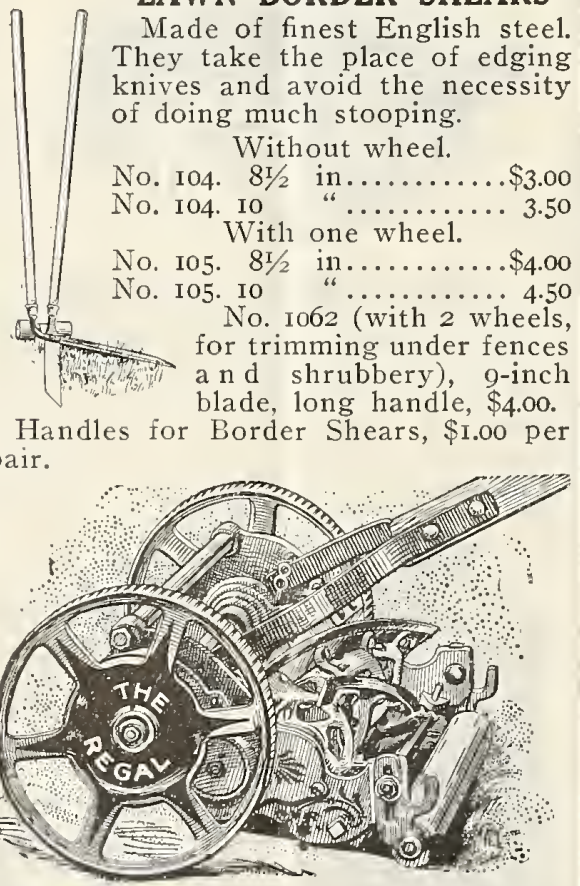

\section{COLDWELL B. B. LAWN MOWER}

I4-in., 5-blade cyl. H.W........\$12.50 I6-in., " " " $" \ldots \ldots \ldots \ldots$ I3.50 I8-in.

20-in., " " " " $"$ "

65 We can also supply Penna., Phila., and I.90 Coldwell Horse and Hand Lawn Mowers, 5.50 also Michell's Ball Bearing, Continental, 7.00 Great American B. B., etc., also Coldwell, 32.50 mers

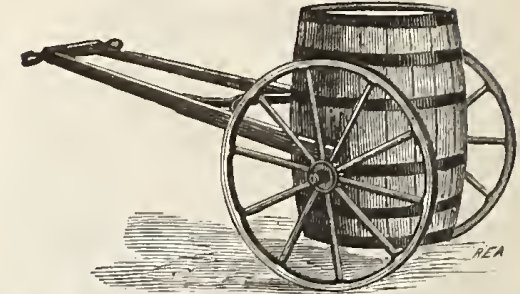

WATER BARREL TRUCKS, Etc.

The price below includes barrel and truck. The barrel may be detached quickly and the leaf rack or stone box may be attached.

$I^{1} / 2$-inch tire truck, all iron wheels

with barrel ............... $\$ 19.00$

$2 \frac{1}{2}$-inch tire truck, all iron wheels

with barrel ................ 19.75

$3^{\mathrm{I} / 2}$-inch tire truck, all iron wheels

with barrel ................ 20.75

Extra Barrels, with trunnions.... 6.00

Stone Boxes for attaching to the

above trucks ............... 4.00

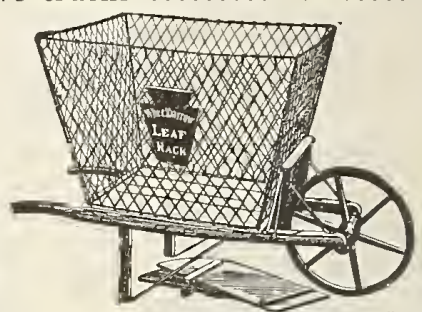

\section{KEYSTONE LEAF RACKS}

This new device can be used on wheelbarrows with removable sides. Convenient for gathering leaves, cut grass and rubbish. Has a capaciy of Io bushels; made of galvanized wire, bolted to a wooden base. Price, not including wheelbarrow, $\$ 7.00$.

\section{LEAF RACKS}

Excellent for gathering leaves, litter, grass, etc. They can be attached to a water barrel truck, shown above, instantly.

Leaf Rack only, no truck........\$12.00 with $\mathrm{I}^{\mathrm{T} / 2 \text {-inch truck....25.00 }}$ with $2 \frac{1}{2}$-inch truck... 25.75 with $3 \frac{1}{2}$-inch truck... 26.75

\section{WHEELBARROWS}

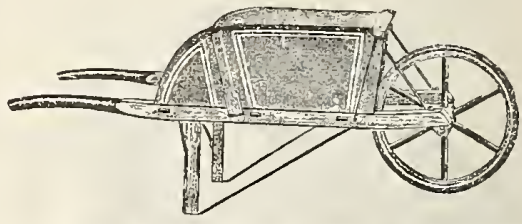

For Farm and Garden and Greenhouse Use

The measurements of barrows are understood, viz: length, meaning inside length of body; depth, inside depth at front; width, outside width at handles.

$\begin{array}{ccccccc} & \text { No. } & \text { Tire Length Depth Width Price } & \text { Lastern } \\ \text { E } 3 & \text { I } / 2 & 28 & \text { I I } & 22 & \$ 6.00\end{array}$

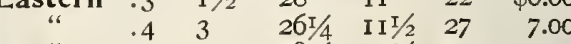
$\begin{array}{lrlrrrr}\text { " } & .5 & 3 & 28 \mathrm{I} / 4 & \mathrm{II} 3 / 4 & 27 & 7.50 \\ & .2 & 2 & 2 \mathrm{I} 3 / 4 & 9 \mathrm{I} / 4 & 20 & 5.50\end{array}$

Canal. Side dump (bolted) ....... 3.75

Special Greenhouse Syle ......... 8.75 


\section{MICHELL'S SPRAYING APPARATUS, ETC.}

THE AUTO-SPRAY

Auto Spray in Operotion

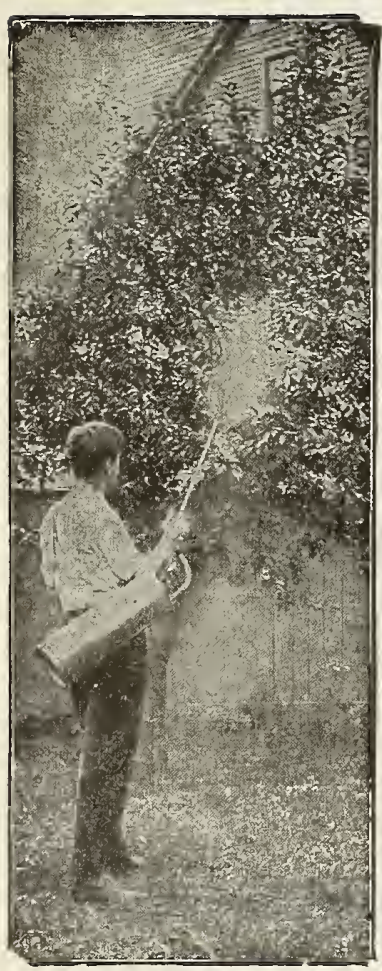

It operates th ere were with comSafe and efficient. Liquid c a p a cit $y, 4$ g a 1 l $10 \mathrm{n}$ s: pressure $c$ apacity, 40 lbs. The Brown is probably the first real suces $\mathrm{c} f \mathrm{u}$ c o $\mathrm{m} p$ ressed air s p r a y e $\mathrm{r}$ ever put on the maret Previous to its i $\mathrm{n} t$ roduction other makes, still being offered for sale. Tre have had a wide and varied e $\mathrm{xp}$ e $\mathrm{r}$ ence with the $\mathrm{d}$ i f $\mathrm{fer}$ en $\mathrm{t}$ ones, an after personal tests and not ing the experiences of our customers. рә7боре Кำuy as our standard compressed air sprayer

this make. No sprayer is sold under broader guarantee for efficiency and durability. The Auto-Spray must please and will accomplish all that any first-class sprayer will, or the purchase price will be refunded. They will successfully spray bushes, shrubbery and trees, the latter with the use of extension brass tank sprayer is the best, as corrosive solutions can be used in it without injuring the same.

No. 1-A. Brass. Equipped with hose and regular nozzle, $\$ 9.50$

No. 1-B. Brass. Equipped with hose and Auto-Pop Attachment, $\$ 10.00$.

No. 1-C. Galvanized Iron. Equipped with hose and regular nozzle, $\$ 6.25$.

No. 1-D. Galvanized Iron. Equipped with hose and Auto-Pop, $\$ 6.75$

Auto-Pop Nozzle Attachment controls the flow instantly by a pressure of the hand. TVhen Auto-Pop Attachment is purchased separately, $\$ 1.75$ each. P. P. weight, $1 \mathrm{lb}$.

No. 22 BINKS COMPRESSED AIR SPRAYER

Galvanized st e el tank, 5 gals. capacity. Brass pump with a patent clamping device, equipped with 3 feet of hose, spray nozzle, shut-off cock and shoulder strap. It is claimed that this is the only compressed air sprayer that will discharge the entire contents with one pumping. P. P. W't., 15 lbs. Price, $\$ 8.00$.

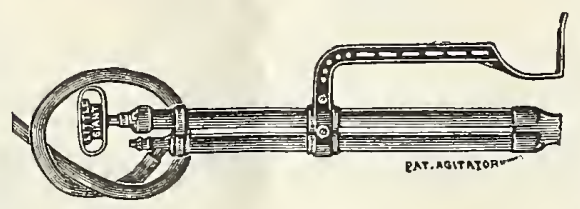

MYERS' BUCKET PUMP

No. $3271 / 2$. This is a double brass chamber arrangement, and fills the want of those desiring a medium priced sprayer. Price, $\$ 5.00$. P. P. weight, 9 lbs.

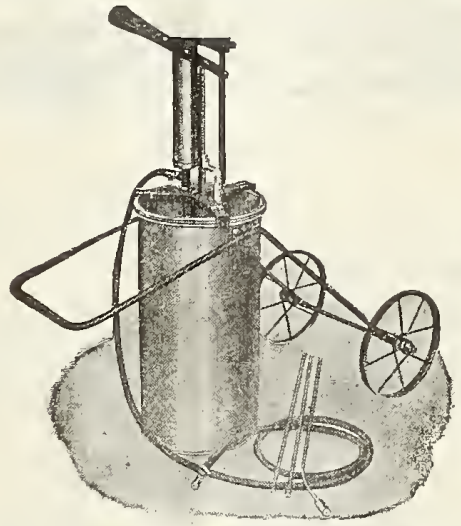

No. 3 Paragon Sprayer

\section{THE PARAGON SPRAYER}

Especially desirable for the reason that it not necessary to strain the material beore pouring it into the reservoir, although we recommend that this be done; guaranfor applying whitewash or paint.

Bucket Washers for Paragon Sprayers, 30c 0. Equipped with a 3-gal. reservoir, 4 ft. of hose, nozzle and extension pipes. Price, $\$ 10.00$

o. 1. With a 5-gal. reservoir, $5 \mathrm{ft}$. of hose and 2 extension pipes, $\$ 12.50$

0. 3. Equipped with a 12-gal. tank mounted on a truck, three $21 / 2-\mathrm{ft}$. extension pipes, 2 nozzles and $10 \mathrm{ft}$. of hose, $\$ 18.00$.

No..4. Mounted on a two-wheel truck; equipped with $10 \mathrm{ft}$. of extension pipe, 20 ft. of hose and 2 uozzles. 25-gal. barrel, complete, $\$ 27.50$

No..4. Without truck, otherwise complete, $\$ 21.00$.

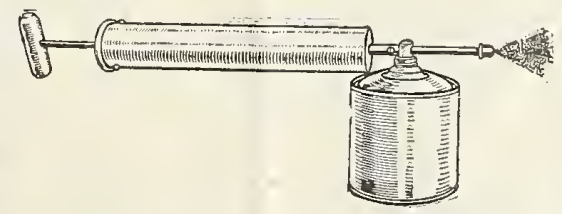

AUTOMATIC COMPRESSED AIR SPRAYER

Parcel Post Weight, 2 lbs.

This is the grandest hand sprazer ever offered, vert easily operated, especially desirable for ladies' use.

Tin... . . each, $\$ 1.00 \mid$ Brass.... each, $\$ 2.00$

\section{CYCLONE HAND SPRAYERS}

Similar to the above except they do not have the automatic air reservoir attachment. P. P. weight, $11 / 2$ lbs.

No. 112. Tin, large, 65c.; Tin, small, 35̌c.; No. 114 , Brass, $\$ 1.25$

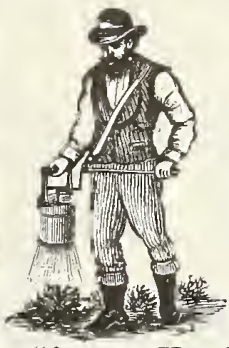

\section{PARIS GREEN} SHAKERS

Tin. For dusting vegetables, potatoes, small fruits and shrubbery, $50 \mathrm{c}$ each. P. P. weight, $2 \mathrm{lbs}$

Farmer's Favorite. (See cut). Large double-action affair, \$2.25 each. P. P. weight, 4 lbs.

"Acre an Hour" Sifter, 75c. P. P. weight, lbs.
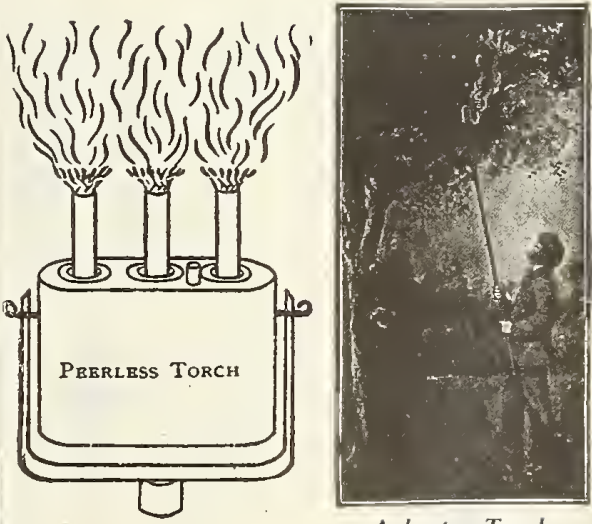

Asbestos Torch

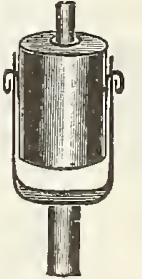

\section{OIL TORCHES}

For burning out worms, cat erpillars and nests that infest trees.

Peerless $\ldots .1$ lb. $\quad \$ 1.00$
Reservoir $\ldots . .1 / 2$ lb.

Asbestos ..... $1 \mathrm{l}$ l $\quad .65$

Reservoir Torch

POLES FOR TORCHES, Etc.

Hard wood, 12 feet, $\$ 1.00 ; 14$ feet, heary, $\$ 1.25 ; 16$ feet, $\$ 1.50$. Poles are not mailable

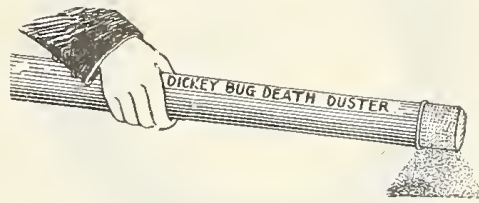

\section{DICKEY DUSTER}

Excellent for distributing Bug Death, Slug Shot, etc. Price, 50c. P. P. weight, $1 \mathrm{lb}$.

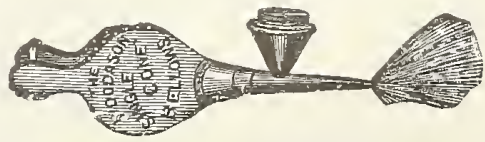

\section{WOODASON BELLOWS}

P. P. W t

Large double cone each. ...5 lbs. $\$ 5.00$ Large single cone, each.....3 lbs. 3.25 Small single cone, each.....2 lbs. 2.25 Sulphur Bellows, each........... 3.00 


\section{GALVANIZEDWIRE STAKES}

No. 10 WIRE, MIGHT

$$
\text { P. P. Wt. }
$$

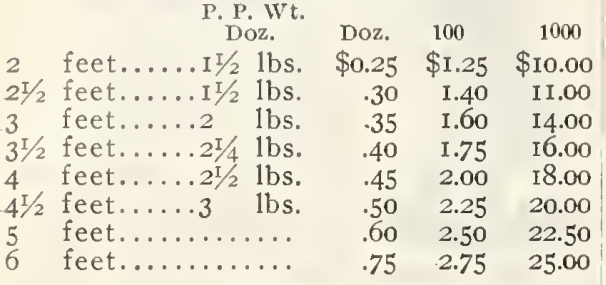

No. 8 WIRE, HEAVY

P. P. Wt.

\begin{tabular}{|c|c|c|c|c|}
\hline & . & Doz. & 100 & 1000 \\
\hline 2 & feet. & $\$ 0.30$ & $\$ 1.75$ & $\$ 13.00$ \\
\hline $21 / 2$ & feet......2 $1 / 2$ lbs. & .35 & 2.00 & 16.00 \\
\hline 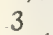 & feet.....23/4 $1 \mathrm{bs}$. & .40 & 2.25 & I 8.00 \\
\hline $3 \%$ & feet. . & .45 & 2.50 & 20.00 \\
\hline 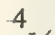 & feet......3 $3^{\mathrm{I} / 2}$ lbs. & .60 & 3.00 & 24.00 \\
\hline $4 I / 2$ & feet....4 & .70 & 3.25 & 27.50 \\
\hline & feet.. & .75 & 3.50 & 30.00 \\
\hline & feet.... & .85 & 4.25 & 37.50 \\
\hline
\end{tabular}
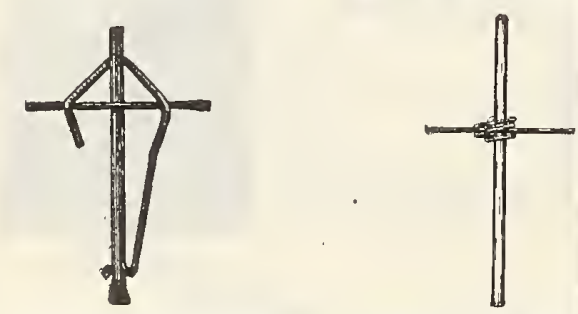

Everlasting Stake Fastener Blake Lock Clip

\section{STAKE FASTENERS}

These take the place of string entirely, lasting several seasons, used for fastening cross wires to galvanized stakes.

\begin{tabular}{|c|c|c|c|}
\hline & per 100 & 500 & 1000 \\
\hline BI & 25 & $\$ 1.00$ & $\$ \mathrm{I} .75$ \\
\hline $\begin{array}{l}\text { verlasting } \\
\text { ureka }\end{array}$ & $.1 / 2$ & 2.25 & 3.75 \\
\hline
\end{tabular}

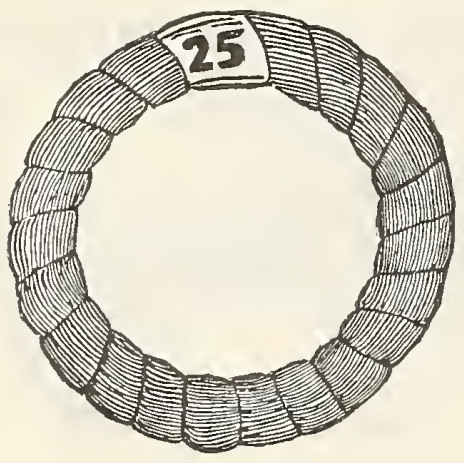

WIRE

Allow for postage if wanted by mail.

12-lb. Lb. Stone

No. 16. Galvanized ....... \$0.20 \$2.20 No. 18. Galvanized .......... $\quad .25 \quad 2.25$ No. 19. Galvanized ......... 28 2.50 No. 20. Galvanized ........... $30 \quad 2.75$ No. 22. Galvanized $\ldots \ldots \ldots \ldots . .32 \quad 3.00$

No. 16. Annealed ......... .20 2.00

No. 18. Annealed …..... .22 2.10

No. 20. Annealed .......... .25 2.50

No. 22. Annealed ........... .30 2.75

PLANT STAKES, WIRE, ETC.

\section{TINNED WIRE}

Used for bunching celery, etc.

No. 19, in 10-1b. boxes, cut $8 \frac{1}{2}$ inches, 3oc. per lb.; per box, $\$ 2.50$.

\section{CUT BOUQUET WIRE}

\section{For Stemming Flowers}

Cut 9, 12 or 18 inches in length. No. 20, 25c. per 1b.; per box, I2 1bs., $\$ 2.50$ No. 22, 27c. per 1b.; per box, 12 lbs., 2.75 No. 24, 30c. per 1b.; per box, I2 1bs., 3.00

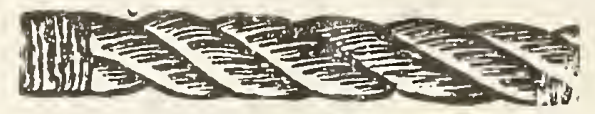

\section{RAFFIA}

For tying, basket making and fancy work, very long and fibrous.

Natural Color. Price, 35c. per I/2 1b.; I 1b. for $70 \mathrm{c}$.

Colored. In all shades. Send for samples of color. In cartons containing about $1 \frac{1}{3}$ Oz., I5c. Allow for postage if Raffia is wanted by Parcel Post.

\section{RAFFIATAPE}

This article is made of a composition of paper and linen and is tremendously strong; it is about $1 / 8$ inch wide and is put up in 250 yard bolts or hanks. This is very desirable for tying bouquets, flower boxes or for any other purpose where attractive tying material is desired. Color, Nile green. Parcel Post Weight, per bolt, $1 / 21 \mathrm{~b}$.

Per bolt of 250 yards, $85 \mathrm{c}$.

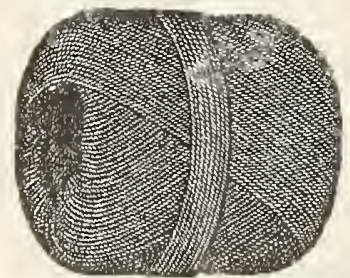

TWINES, ETC.

No. I2, Light Italian .......\$0.22 $\$$

No. 18 , Medium Italian ...... .22

No. 24, Heavy Italian ....... .22

No. 36, Heavy Italian ....... .22

Jute, 2 ply, 3 ply and 5 ply... .22

Linen Bouquet ............. .15

Boston Linen, 2 and 3 ply.... .40

Green Sea Island ............ I5

Special Thin White Cotton.. .20

Tarred, for Mat Making..... .30

Tarred Sisal for Fodder.....

Binder (balls weigh $8 \mathrm{r} / 3$ lbs.)..

Express, very heavy......... 30

Green Silkaline. For stringing Smilax and Asparagus, etc. F, fine; FF, medium; FFF, coarse.

Price, per spool, $30 \mathrm{c}$.

Price, per 1b. (8 spools), \$2.25.

Green Linen (substitute for Silkaline), very similar to the above, fast color. Price, 40c. per spool; $\$$ r.25 per $1 \mathrm{~b}$.

\section{GREEN TAPERING STAKES Painted Green \\ Weight per Doz. Wach Doz. 100

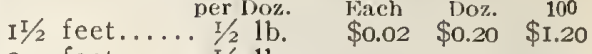 2 feet..... I $1 / 2$ lb. $\quad .04 \quad .35 \quad 2.10$ $2 \mathrm{I} / 2$ feet...... I lb. $\quad .05 \quad .45 \quad 3.00$ 3 feet...... I I l lbs. .06 $\quad .65 \quad 4.00$ $3^{1 / 2}$ feet...... I I $/ 2$ lbs. $\quad .07 \quad .75 \quad 5.00$ $\begin{array}{rrrrr}4 & \text { feet...... Ibs. } & .09 & .90 & 6.00 \\ 5 & \text { feet........... } & .0 & \text { I.00 } & 7.00\end{array}$}

ROSE OR DAHLIA STAKES

Round tapering style; painted green.

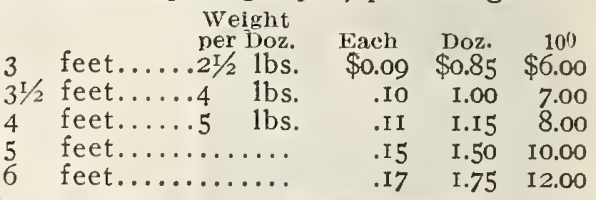

\section{SQUARE PLANT STAKES}

These are painted green and nicely tapered and finished.

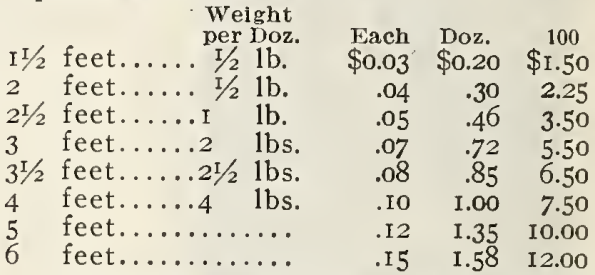

\section{WOOD DOWEL STAKES}

Length Diam. per Doz. Doz. $100 \quad 1000$ 24 in...3/8 in ... 1 lb. \$0.15 \$0.85 \$7.50 36 in...1/4 in ... 3/4 lb. $\quad .20$ r.00 8.50 36 in... 16 in... 3/4 lb. .20 I.00 8.50 36 in... 56 in... 1 1b. .20 r.00 8.50 36 in... $3 / 8$ in... $\mathrm{r} / 4 / 4$ lbs. .20 r.00 8.50 36 in...5 in .. 3 lbs. .25 I.50 12.50

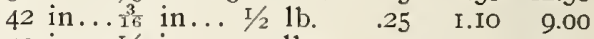
$42 \mathrm{in...1/4}$ in... I lb. .25 I.Io 9.00 $42 \mathrm{in...5} \frac{56}{16}$ in... I I/2 lbs. .25 I.I0 9.00 42 in... $3 / 8$ in... I $1 / 2$ lbs. .25 1.10 9.00 42 in...5 in .. 4 lbs. .30 I.75 I5.00 The above are plain stakes, if wanted dyed green add 5c. per doz.; 25c. per Ioo; per 1000, $\$ 2.00$ to the above prices.

CANE STAKES (NaturaI)

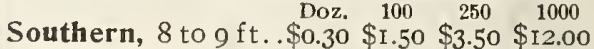
$\begin{array}{lllll}\text { Japanese, } 5 \text { to } 6 \mathrm{ft} \text {.. } & .25 & \text { r.75 } & 4.00 & \text { I } 5.00\end{array}$

\section{JAPANESE GREEN CANE STAKES}

These are very attractive for all purposes of plant staking, thin and very $\begin{array}{lllll}\text { strong. } & \text { Doz. } & 100 & 500 & 1000\end{array}$ $\mathrm{x} 1 / 2$ feet $\ldots \ldots \ldots$ \$o.15 $\$$ I.oo $\$ 4.50 \quad \$ 8.50$ 2 feet ..........20 $\quad .20 \quad 1.25 \quad 5.25$ I0.00

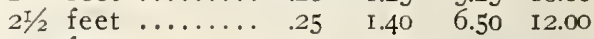
3 feet $\ldots \ldots \ldots .30$. 30 I.50 7.00 I 3.00

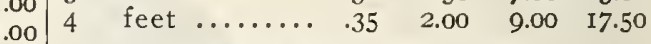

\section{BAMBOO POLES}

.30 I5 ft., very strong; used extensively .35 for brushing worm casts off Putting Greens, also for staking young trees. Each, 35c.; doz., \$3.75; \$27.50 per I00.

\section{HYACINTH STAKES}

Used for staking hyacinths, tulips and slender plants; dyed green.

\begin{tabular}{|c|c|c|c|c|c|}
\hline $5 \mathrm{inc}$ & & $\begin{array}{l}\text { Wt. } \\
100 \\
\text { lbs. }\end{array}$ & $\begin{array}{l}\text { Doz. } \\
\$ 0.05\end{array}$ & $\$ 0.15$ & $\begin{array}{c}10^{200} \\
\$ 0.75\end{array}$ \\
\hline $12 \mathrm{i}$ & $\ldots 22$ & lbs. & .05 & .25 & 1.50 \\
\hline 8 & $\ldots . .2$ & lbs. & .08 & .40 & 2.00 \\
\hline
\end{tabular}




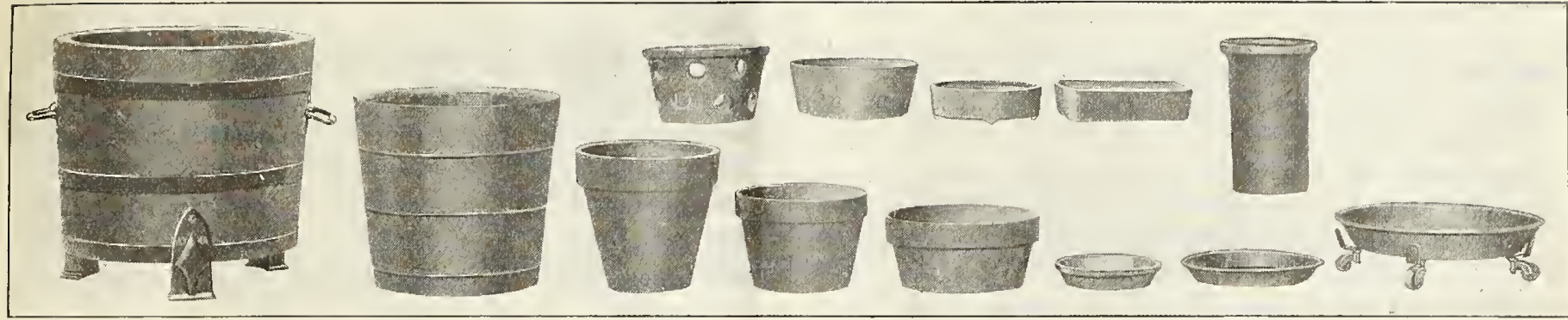

Cedar Tub

\section{CEDAR TUBS}

Equipped with Strong Iron Handles

These are made by hand, of the very best white cedar painted green, bound with black iron hoops.

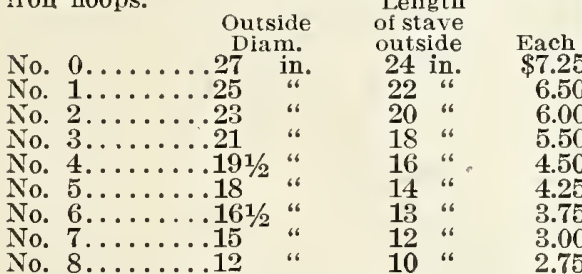

\section{MICHELL'S KEYSTONE} PLANT TUBS

Made of white cedar, painted green and bound with strong electric welded wire hoops, which do not rust. Handles are sold separately at $15 \mathrm{c}$. per pair. Not attached to tub.

No. $1 . \ldots \ldots \ldots 6$ in.

No. $2 \ldots \ldots \ldots+7$.

No. $3 \ldots \ldots+8$.

No. $4 \ldots \ldots \ldots, 9$ " 9

No. $5 \ldots \ldots \ldots 10$.

No. $6 \ldots \ldots \ldots \ldots 11$ "

No. $8 \ldots \ldots \ldots \ldots 13$

No. $9 \ldots \ldots \ldots 14$

No. $10 \ldots \ldots \ldots 15$

No. $11 \ldots \ldots \ldots 16$

No. $12 \ldots \ldots \ldots \ldots 17$

No. $13 \ldots \ldots \ldots \ldots 18$

No. $14 . \ldots \ldots \ldots 19$

\section{KEYSTONE FERN TUBS}

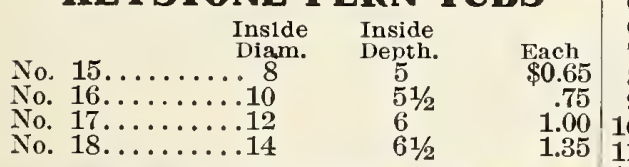

\section{PAPER FLOWER POTS}

Ins. Parcel Post Weight

Diam, per doz, per 100 per doz. $100 \quad 1000$

$21 / 4 \ldots .3$ ozs. 2 lbs. $\$ 0.08 \quad \$ 0.45 \$ 3.50$

$21 / 2 \ldots .3$ ozs. 2 lbs. $\quad .10 \quad .50 \quad 4.00$

3 …5 5 ozs. 2 lbs. $\quad .15 \quad .75 \quad 5.25$

$31 / 2 \ldots 7$ ozs. 3 lbs. $\quad .20 \quad 1.10 \quad 7.40$

$4 \cdots 8$ ozs. 4 lbs. $\quad .25 \quad 1.25 \quad 9.05$

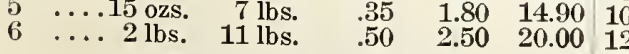

\section{AZALEA POTS}

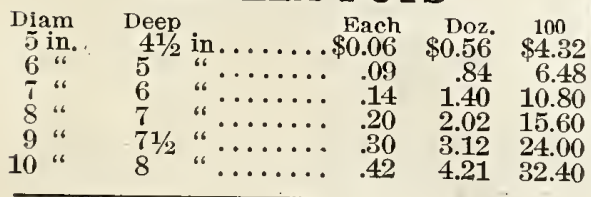

50

.2512

00

,

Earthen
Flower Pot

Azalea
Pot percelain ferneries.

$\begin{array}{lllll}\text { WVidth } & \text { Depth } & \text { Each } & \text { Noz. } & 100 \\ 7 \text { in. } & 17 / 8 \text { in. } & \$ 0.14 & \$ 1.40 & \$ 10.80\end{array}$

6 inches square........\$0.75

6 inches square..........

No. Depth Depth weight Each Doz.

EARTHEN BULB PANS 6 inches diam......\$0.09 $\$ 0.84$

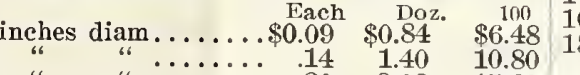
$\begin{array}{llll}\text { “. } \ldots \ldots \ldots & .20 & 2.02 & \mathbf{1 0 . 8 0}\end{array}$ $\begin{array}{lllll}\text { "........ } & 30 & 3.12 & 24.00\end{array}$

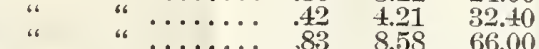

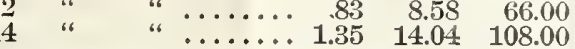
WOODEN ORCHID BASKETS

\section{FERN DISH LINERS}

These cannot be sent by Parcel Post.

Very shallow, for inside of fancy silver or

\section{SEED PANS (Earthenware)}

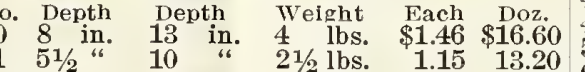

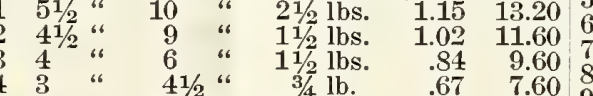

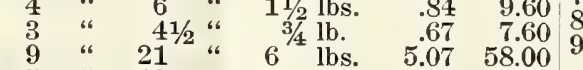

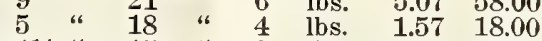

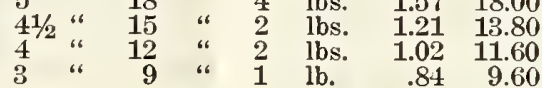

.

\section{EARTHENWARE SAUCERS}

These cannot be sent by Parcel Post.

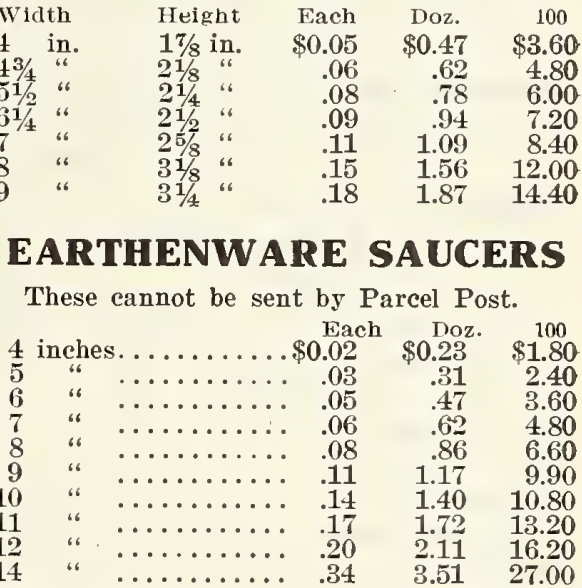

\section{WOOD FIBRF SAUCERS}

Extremely desirable on account of being absolutely waterproof.

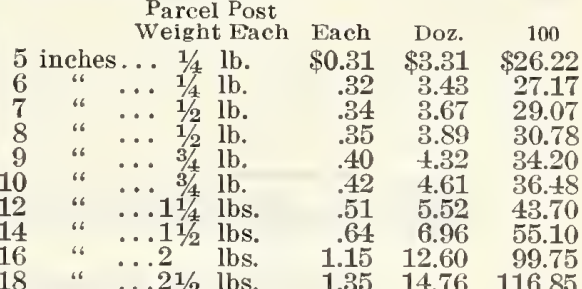

ORCHID PANS (Round) (Emrthen) 4 inches $\operatorname{diam} \ldots \ldots \ldots \ldots \ldots \$ 0.12 \quad \begin{gathered}\text { Each } \\ \$ 1.25\end{gathered}$

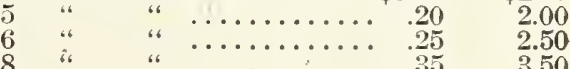

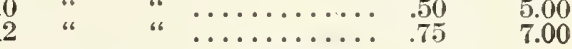

\section{EARTHEN FERN PANS}

These cannot be sent by Parcel Post.

29.70

49.50

79.20

$\begin{array}{rrr}1.40 & 10.80 & 99.00 \\ 2.02 & 15.60 & 143.00\end{array}$

$3.12 \quad 24.00$

$4.21 \quad 32.40$

$\begin{array}{llll}\cdots \cdots & .42 & 4.21 & 32.40 \\ \cdots & .60 & 6.24 & 48.00\end{array}$

$\begin{array}{llll}\cdots & .60 & 6.24 & 48.00\end{array}$

$\begin{array}{rr}8.58 & 66.00 \\ 14.04 & 108.00\end{array}$

(Square) Each

Ins.

$\$ 4.0014$

5.0016

5.7518 .

$\begin{array}{l:l}5.50 & 20 .\end{array}$

8.75

Larger sizes can be furnished as complete

ROLLING STANDS

(Wood Flbre)

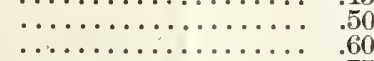

.75

\begin{tabular}{|c|c|c|c|}
\hline \multirow{2}{*}{$\begin{array}{c}\text { Parcel Post } \\
\text { Weight }\end{array}$} & \multicolumn{2}{|c|}{ Will Fit } & \multirow{3}{*}{$\begin{array}{l}\text { Each } \\
\$ 1.05\end{array}$} \\
\hline & Pot & Iub & \\
\hline lbs. & $10 \mathrm{in.}$ & & \\
\hline & & No & \\
\hline & 16 “ & " & $\begin{array}{l}1.1 \\
2.1\end{array}$ \\
\hline & & & \\
\hline
\end{tabular}




\section{DIRECTIONS FOR USING ANY OF THE FOLLOWING WILL BE FOUND ON EACH PACKAGE}

Ant Exterminator. Per I/4 1b., 20c.; per $1 / 2$ 1b., 40c.; per 1b., $75 \mathrm{c}$.; per 5 lbs., $\$ 3.00$.

Antipest (Carman's). \$1.75 per gal.

Aphine. $1 / 4$ pt., 25c.; per $1 / 2$ pt., 40c.; per pt., 65c.; per qt., $\$ 1.00 ;$ gal., $\$ 2.50$.

Aphis Punk. Per pkg., 60c.; I2 pkgs., $\$ 6.50$.

Arsenate of Lead (Powdered). I 1b., 90c.; per 5 lbs., \$2.75; per Io $1 \mathrm{bs} ., \$ 5.25$; per $25 \mathrm{lbs}$., $\$ 12.00$; per 50 lbs., $\$ 23.00$; per IOO 1bs., $\$ 42.50$,

Arsenate of Lead (Paste). Per 1b., 40c.; 5 lbs., \$1.75; Io lbs., $\$ 3.50 ; 25$ lbs., $\$ 6.50 ; 50$ lbs., $\$ 12.50$; I00 1bs., $\$ 24.00$.

Black Leaf No. 40. Per I-oz. bottle, 25c.; I/2 1b., 75c.; 2 lbs., $\$ 2.50$; Io 1bs., \$10.75.

Bordeaux Arsenate. Per 1b., 35c.; 5 1bs., \$I.50; Io 1bs., \$2.75; 25 lbs., $\$ 6.00 ; 50$ lbs., $\$$ I I.00; $\$ 2 \mathrm{I} .00$ for I00 $1 \mathrm{bs}$.

Bordeaux Mixture (Dry Form). Per 1b., 30c.; 5 1bs., \$1.25; Io lbs., $\$ 2.00$.

Bordeaux Mixture (Paste Form). Per 1b., 6oc.; gal., \$1.50; 5 gals., $\$ 6.00$.

Boro Wax. Per qt., 40c.; I/2 gal., 75c.; per gal., \$I.25.

Bug Death. Per 1b., 20c.; 3 lbs., 45c.; 5 lbs., 65c. ; I2 $2 / 2$ 1bs., $\$ \mathrm{I} .25 ; \mathrm{I} 00 \mathrm{lbs}$., $\$ 8.50$.

Carbolineum (Arvenarius). Per gal., \$1.50.

Copper Solution. Per qt., \$1.00; per gal., \$2.75.

Cut Worm Destroyer (Reade's). Per 1b., 25c.; 5 1bs., 8oc.; Io lbs., $\$ 1.25 ; 25$ 1bs., \$2.50; per I00 1bs., $\$ 7.50$.

Cyanegg. Per 1b., \$1.00.

Dalmatian or Persian Powder. Per I/4 1b., 30c.; I/2 1b., 55c.; 1b., 90c.; 5 1bs., $\$ 4.00$.

Fir Tree Oil Soap. Per I/2 1b., 35c.; per 2-lb. can, $\$ 1.00$.

Fish Oil Soap. Per I/2 1b., I5c. per 1b., 25c.; 5 lbs., \$I.00; 25 lbs., $\$ 3.00$; I00 1bs., $\$ 9.50$.

Fish Oil Soap (Good's Caustic). Per Ib., 30c.; 5 1bs., \$I.25; 25 lbs., $\$ 4.75$.

Fungine. Per qt., \$1.00; per gal., \$3.50.

Getz=There Soap. Per 2 lbs., 50c.; 8 lbs., \$1.75; 25 lbs., $\$ 2.75$. Grape Dust. Per 5 lbs., 75c.; Io lbs., \$I.40.

Hellebore. Per I/4 1b., 25c.; I/2 1b., 40c.; 1b., 65c.; 5 1bs., \$3.00. IXL Compound. Per gal., \$4.00.

Kerosene Emulsion (Liquid). 6oc. per qt.; per gal., \$1.50. Kil=o=Scale, Per pt., 35c.; qt., 6oc.; I/2 gal., 85c.; gal., $\$ 1.35$; 5 gals., $\$ 5.50$.

Lemon Oil Insecticide. Per I/2 pt., 30c.; pt., 50c.; qt., 90c.; I/2 gal., \$1.50; gal., \$2.50; 5-gal. keg, \$10.50.

Lime Sulphur. Per qt., 6oc.; I gal., \$1.25; 5 gals., \$4.75.

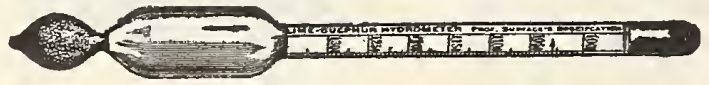

\section{CARBONDALE HYDROMETERS}

These are highly recommended by the Pennsylvania State Department of Agriculture for testing the gravity of Lime Sulphur solution; one should be in the hands of every man who uses this material. Price, \$1.00. (Postpaid, \$I.Io.) With directions.

Lime Sulphur, Modoc Brand (Dry Powder Form). I 1b., 25c.; 5 lbs., \$I.00; 10 lbs., \$I.75; 25 lbs., $\$ 3.50 ; 50$ lbs., $\$ 6.00 ; 300-1 b$. bbl., at Ioc, per lb.
Nico=Fume (Liquid). T/4:1b., 50c.; 1b., $\$ 1.50 ; 4$ lbs., $\$ 5.50 ; 8$ lbs., $\$$ I0.50.

Nico=Fume Paper. Per box, 24 sheets, 85c.; per 144 sheets, $\$ 4.00 ; 288$ sheets, $\$ 7.50$.

Nicoticide. At the present time this material is not obtainable. Lamps for Nicocide and similar products, 6oc. each.

Nikoteen. I/2 oz., I5c.; I3/4 Ozs., 40c.; 8 ozs., 85c.; pt., $\$$ I.50; per gal., \$Io.oo.

Paris Green. Per I/4 lb., 20c.; 1/2 lb., 35c.; 1b., 65c.; 2 1bs., \$1.25; I4 lbs., $\$ 8.40$.

Pyrox (Bowker's). Per lb., 40c.; 5 lbs., \$1.50; Io 1bs., \$2.75; 25 lbs., \$6.00; 50 lbs., \$10.75; 100 lbs., \$20.00; 300 lbs., \$57.00.

Readeana Rose Bug Exterminator. Trial bottle, 30c.; 8 ozs., 50c.; 24 Ozs., $\$ 1.00$; per gal., $\$ 4.00$.

Scalecide. Per qt., 55c.; gal., $\$ \mathrm{I} .35 ; 5$ gals., $\$ 5.00$; Io gals., $\$ 9.00 ;$ 30-gal. bbl., $\$ 21.00 ; 50$ gals., $\$ 32.00$.

Scale Destroyer (Soluble Oil). Qt., 50c.; I/2 gal., 85c.; gal., $\$ 1.25 ; 5$ gals., $\$ 4.25$; Io gals., $\$ 8.00 ; 30$ gals., $\$ 19.50 ; 50$ gals., $\$ 30.00$.

Shoo Fly. Per qt., 45c.; per gal., \$1.25.

Slug Shot. Per canister, 20c.; 5 lbs., 50c.; Io lbs., 9oc.; 25 lbs., $\$ 2.15$.

Sulphate of Copper. Per Ib., 25c.; per io lbs., $\$ 2.00$.

Sulphur (Flowers). Per 1b., I5c.; 5 lbs., 60c.; 25 1bs., \$2.00; I00 lbs., $\$ 7.50$.

Sulphur Candles. Large: 25c. each; per doz., \$2.50. Sma11. i5c. each; $\$ 1.50$ per doz.

Sulpho Tobacco Soap. Per 3-Oz. pkg., I5c.; 8-oz. pkg., 25 c.

Tobacco Dust (Special Dusting or Fumigating). $5 \mathrm{lbs}, 35 \mathrm{c}$; Io lbs., 6oc.; 25 lbs., \$1.35; 50 lbs., $\$ 2.50$; I00 lbs., $\$ 4.00$.

Tobacco Soap (Sulpho). 3 ozs., 15c.; 8 ozs., 25c.

Tobacco Stems. Per 1b., Ioc.; 5 lbs., 25c.; barrel sacks, \$1.25; large bales at $\$ 2.00$ per 100 lbs.

Thrip Juice (Hammond's No. 2). Pt., 75c.; qt., \$I.25; gal., $\$ 4.00$.

Tree Tanglefoot. Per 1b., 50c.; 3-1b. cans, $\$$ I.45; 10 $1 \mathrm{bs} ., \$ 4.50$; 20 lbs., $\$ 8.75$.

Vaporite. I lb., I5c.; per 5 lbs., 60c.; Io $1 \mathrm{bs} ., \$ 1.00 ; 25$ lbs., $\$ 2.25$; 50 lbs., $\$ 4.25$; 100 lbs., $\$ 7.50$.

Vermine. Per qt., $\$ 1.00 ; \$ 3.00$ per gal.

Vapor Cones (Lethorion Nicotine). In 3 sizes: No. I, I5c. each; doz., \$I.5o. No. 2, 25c. each; doz., \$2.50. No. 3, 30c. each; doz., \$3.00.

Worm Destroyer (Michell's Brand). Owing to European complications we are unable to supply this at the present time.

Worm Destroyer (Carter's Brand). F. o. b. Philadelphia : per Ioo lbs., $\$ 7.50$; per 500 lbs., $\$ 35.00$; ton, $\$ 130.00$. F. o. b. Boston: I00 lbs., $\$ 7.50$; ton, $\$ 120.00$.

Worm Eradicator (Reade's Electric). Small size, 3oc.; 8 ozs., 50c.; 24 ozs., \$1.00; per gal., \$4.00.

Zenoleum. I/2 pt., 30c.; qt., 60c.; $1 / 2$ gal., $\$$ I.00; $\$$ I.75 per gal. 


\section{Michell's High Grade Fertilizers}

\section{ALL PRICES SUBJECT TO MARKET CHANGES}

Animal Bone and Potash. Apply 400 to 600 lbs. per acre. Price ou application.

Ashes (Canadian Hard Wood). Apply 1000 lbs. per aere. Per 10 lbs., 40c.; 25 lbs., 70c.; 50 lbs., $\$ 1.15$; 100 lbs., $\$ 2.00 ; 200$ lbs., $\$ 3.75$; toll, $\$ 30.00$.

Ashes (Domestic Hard Wood). Not less than 100 lbs. sold. 100 lbs., $\$ 2.75$; 1/2-ton, $\$ 13.00$; ton, $\$ 25.00$.

Acid or Rock Phosphate. Apply 1000 lbs. per acre. In 200-1b. sacks only, \$3.25; per ton, $\$ 25.00$.

Asparagus Fertilizer (Pure Bone and Potash). Apply 600 lbs. per acre. 25 lbs., $\$ 1.00 ; 50$ lbs., $\$ 1.75 ; 100$ lbs., $\$ 3.00 ; 200$ lbs., $\$ 5.50$; ton, $\$ 42.50$.

Bon Arbor. Powder: 16 lb., 30e.; per 1 lb., 50c.; $\$ 1.80$ per 5 lbs.

Blood (Dried). Apply 300 lbs. per acre. 5 lbs., $75 \mathrm{c} . ; 10$ lbs., $\$ 1.25$; 25 lbs., $\$ 2.25 ; 50$ lbs., $\$ 4.00 ; 100$ lbs., $\$ 7.50 ; 200$ lbs., $\$ 14.00$.

Blood Flour. Apply 200 lbs, per acre. F. o. b. Philadelphia: 5 lbs., 75c.; 10 lbs., $\$ 1.40 ; 25$ lbs., $\$ 2.55 ; 50$ lbs., $\$ 5.00 ; 100$ lbs., $\$ 9.50$.

Bone Meal (Michell's Special Brand). 3 lbs., 25e.; 5 lbs., 35e.; 10 lbs., 60e.; 25 lbs., $\$ 1.10 ; 50$ lbs., $\$ 1.70 ; 100$ lbs., $\$ 3.25 ; 200$ lbs., $\$ 6.75$; $1 / 2$-ton, $\$ 32.50$; ton, $\$ 60.00$.

Bone (Coarse Cracked). Price on application.

Bone (Coarse Ground). Apply 600 to 800 lbs. per acre. Price on application.

Bone Flour (Special Superfine Grade). In 100-Ib. bags only. Price f.o.b. Philadelphia. $100 \mathrm{lbs.,} \$ 3.50 ; 200 \mathrm{lbs} ., \$ 6.75$; ton, $\$ 60.00$.

Chrysanthemum Manure (Thompson's Special). 28-1b. sack, $\$ 4.75 ; 56$ - lb. sack, $\$ 3.00$.

Climax Lawn Sand. (See Lawn Sand.)

Clay's Fertilizer. Not obtainable at present.

Copperas (Sulphate of Tron). Price on application.

Cotton Seed Meal. Apply 600 lbs. per acre. 5 lbs., 40e.; 10 lbs., 75e.; 25 lbs., $\$ 1.50 ; 50$ lbs., $\$ 2.75 ; 100$ lbs., $\$ 5.00$; ton, $\$ 75.00$.

Corn Phosphate. (See Phosphate.)

Cow or Cattle Manure (Shredded). F. o. b. Philadelphia. 5 lbs., 35c.; 60c. for 10 lbs.; 25 lbs., $\$ 1.00 ; 50$ lbs., \$1.75; 100 lbs., $\$ 3.25 ; 500$ lbs., $\$ 15.00 ; 1000$ lbs., $\$ 26.00$; ton, $\$ 50.00$.

Dissolved Bone. Apply 600 to 800 lbs. per aere. Price on ap plication.

Horse Manure. (See Manure.)

Humus (Alpliano) Natural. F. o. b. factory: 100 lbs., $\$ 1.00$; 500 lbs., $\$ 3.75 ; 1000$ lbs., $\$ 5.00$; ton, $\$ 8.00$. F. o. b. Plilladel phia: 100 lbs., $\$ 1.35 ; 500$ lbs., $\$ 6.25 ; 1000$ lbs.. $\$ 12.00$; ton $\$ 20.00$.

Humus (Alphano) Prepared. F. o. b. factory: 100 lbs., \$1.10; 500 lbs., $\$ 5.00 ; 1000$ lbs., $\$ 8.50$; ton, $\$ 16.00$. F. o. b. Philadelphia, 5 lbs., 25e.; 25 lbs., 65e.; 50 lbs., \$1.00; 100 lbs., \$1.75; 500 lbs., $\$ 9.00 ; 1000$ lbs., $\$ 13.50$; ton, $\$ 25.00$.

Horn Shavings. 5 lbs., 50c.; 25 lbs., $\$ 2.00 ; 50$ lbs., $\$ 3.25 ; 100$ lbs., $\$ 6.00$.

Kainit (Potasly Salts). Apply 800 to 1000 lbs, per acre. Stoch unprocurable at this time.

Land Plaster. Apply 1000 to 1500 lbs. per aere. 5 lbs., 25e.; 10 lbs., 40c.; per 25 lbs., 60c.; 50 lbs., $\$ 1.00$; 100 lbs., $\$ 1.75$; 200 lbs., $\$ 3.00$; ton, $\$ 22.00$.
Irawn Sand (Climax). 31/2-1b. tin, 60c.; 7 lbs., $\$ 1.00 ; 14$ lbs., $\$ 1.75 ; 28$ lbs., $\$ 3.00 ; 56$ lbs., \$4.50; 112-lb. keg, $\$ 8.50$.

Limestone (Pulverized). Apply 1 ton per acre. Per 100-1b. bag, $\$ 1.50$; 1000 lbs., $\$ 8.00$; per ton, $\$ 15.00$.

Lime (Hydrated or Powdered). 125-1b. sack, $\$ 2.00 ; 500$ lbs., $\$ 9.00 ; 1000$ lbs., $\$ 15.00$; per ton, $\$ 22.00$.

Manure, Horse, Cow or Stock Yard. Prices quoted on request. Carload lots only.

Mulford's Culture (Bacteria for Legumes). 1/t acre size bottle, $50 \mathrm{c}$; per acre bottle, $\$ 1.50 ; 5$ acre bottle, $\$ 5.00$.

Mapes Fertilizers. Prices quoted on application.

Muriate of Potash. Stock unprocurable at this time.

Elant Food (Bowker's). Small pkgs., 15c. each; large pkgs., 25c. each.

Plant Food (Michell's). 6-oz. pkgs., 15c.; 50e. for 4 pkgs. (byr Express, not prepaid).

Nitrate of Soda. Apply 100 to 150 lbs. per acre. 5 lbs., $\$ 1.50$; 10 lbs., $\$ 2.50 ; 25$ lbs., $\$ 4.50 ; 50$ lbs., $\$ 3.00 ; 100$ lbs., $\$ 15.00$; 200 lbs., $\$ 25.00$; $1 / 2$ ton, $\$ 50.00$; per ton, $\$ 150.00$.

Phosphate (High Grade Ammoniated). Apply 500 to 600 lbs. per acre. 5 lbs., 30e.; $50 \mathrm{c}$. for 10 lbs.; 2.5 lbs., $85 \mathrm{c} . ; 50$ lbs., $\$ 1.50 ; 100$ lbs., $\$ 2.75 ; 200$ lbs., $\$ 5.50 ; \$ 25.00$ per 1000 lbs.

Phosphate for Corn (Phosphate and Potash). Apply 500 to $600 \mathrm{lbs}$. per acre. $200 \mathrm{lbs}$., $\$ 5.50 ; \$ 26.00$ per $1000 \mathrm{lbs}$; t toll, $\$ 52.00$.

Phosphate (Michell's Hi-Grade Potato). Apply 400 to 600 lbs. per acre. Caunot supply at present.

Phosphate (Basic Slag). Apply 600 to 800 lbs, per acre. Price on application.

Potato Fertilizer. Apply 400 lbs. per acre. 25 lbs., $\$ 1.00 ; 50$ lbs., $\$ 1.65 ; 100$ lbs., $\$ 3.00 ; 200$ lbs., $\$ 5.75$; ton, $\$ 55.00$.

Poudrette (Native Guano). Apply 1000 lbs. per acre. 5 lbs., $25 \mathrm{c}$; $10 \mathrm{lbs.,} 45 \mathrm{c}$; $2.5 \mathrm{lbs} ., 75 \mathrm{c} . ; 100$ lbs., $\$ 2.00 ; 200$ lbs., $\$ 3.50$; 1000 lbs., $\$ 16.00$; ton, $\$ 30.00$.

Salt (Agricultural). Apply 600 to 800 lbs. per acre. 25 lbs., 60 c., 100 lbs., $\$ 1.75$; 200 lbs., $\$ 3.00$; ton, $\$ 25.00$.

Sheep Manure (Wizard Brand). Apply 1000 lbs. per acre. 5 lbs., 35e.; 10 lbs., 60e.; 25 lbs., $\$ 1.00 ; 50$ lbs., $\$ 1.75 ; 100$ lbs., $\$ 3.25 ; 500 \mathrm{lbs.}$ \$ $\$ 15.00 ; 1000 \mathrm{lbs} ., \$ 26.00 ;$ ton, $\$ 50.00$.

Soot (Imported Scotch). 10c. per lb.; 5 lbs., 40c.; 25 lbs. $\$ 1.25$; 112 lbs.. \$4.00.

Sulphate of Ammonia. Apply 75 to 100 lbs. per acre. 5 lbs., 70c.; 10 lbs., $\$ 1.35$; 25 lbs., $\$ 3.25 ; 100$ lbs., $\$ 10.00$.

Sulphate of Potash. Stock not procurable at this time.

Tankage. 5 lbs., 35c.; 10 lbs., 50e.; 25 lbs., $\$ 1.00$; 50 lbs., $\$ 1.50$; 100 lbs., $\$ 2.75 ; 200$ lbs., $\$ 5.00$.

Thompson's Special Flower, Vegetable and Vine Manure. 15e per lb.: 5 lbs.. 60c.; $\$ 1.10$ per 10 lbs., 29 lbs., \$2.50; 56 lbs., $\$ 4.50$.

Wheat Fertilizer. Apply 500 to 600 lbs. per acre. Price on ap plieation.

Tobacco Stems. Per 1b., 10e.; 25c. per 5 lbs.; in large bales, at $\$ 2.25$ per 100 lbs.

Wood Ashes. (See Ashes.) 


\section{CA Weed Killer for Use on Lawns}

THE NEW WAY

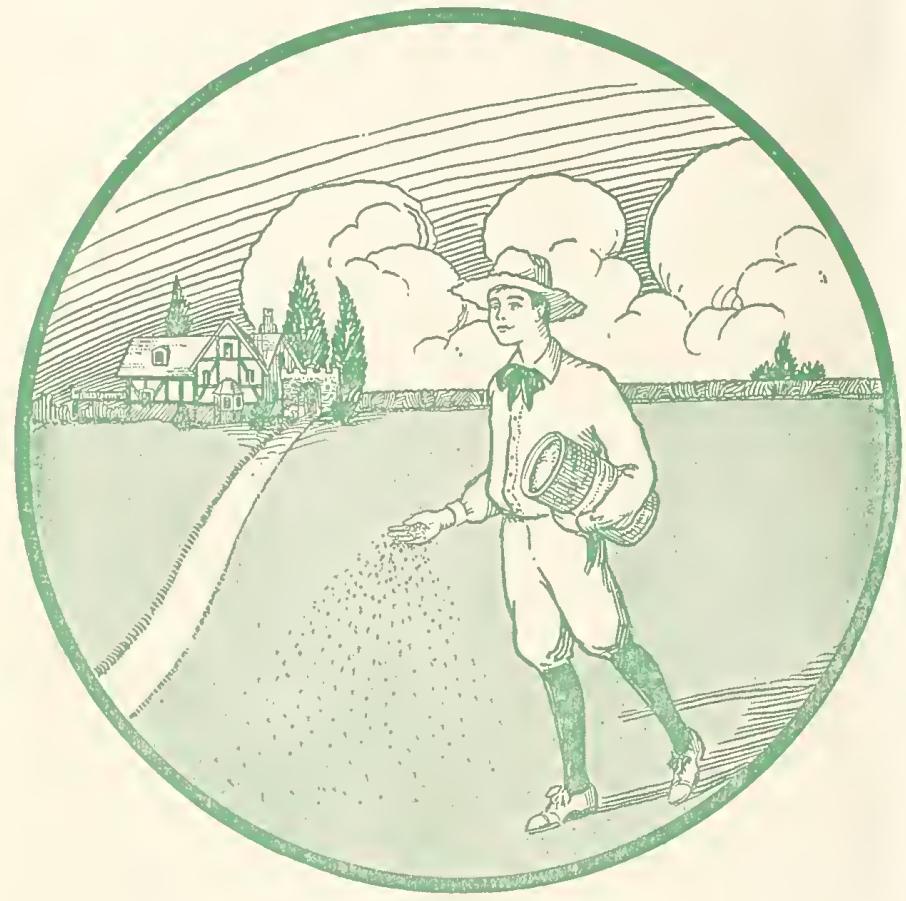

Showing method of applying CLIMAX LAWN SAND for destrosing

\section{CLIMAX LAWN SAND}

"Climax Lawn \$and" is a unique combination of fincly ground clicmi. cals, which, when sprinkled over the grass, possess the remurkublc jroperty of destroying Mloss, Chickweed, Plantains, Dandelion, and all other weeds on Lawns, Tennis Courts, Golf Greens, etc., at the samc time promoting the growth of the finer grasses.

"Climax Lawn Sand" may be applicd any time during the growing season of the year, namely, from beginning of April to the end of October.

The lawn must be absolutely dry; by that is meant that no rain or dew must be visible on the grass.

Ten to twclve a. m. during the montls of April, May and October, ninc to twelve a. m. during June, July, August and Septcmber.

Only apply in fine weather when the temperature is fairly high and when no rain appears likely for a day or two. This is mosi important.

After applying, the weeds blacken and die; the griss usually also becomes blackencd and may remain so for a few days. but it quickly recovers its color, and young growths appear on the bare spots previously occupicd by the weeds.

Should the weather be very hot and dry, the lawn should be thoroughly watered at the expiration of 48 hours after the application.

It Acts as one of the most powerful fertilizer's for grasses if applied as a top-dressing in the early spring. For top dressing as a fertilizer apply $1 / 4$ ton per acre.

QUANTITY REQUIRED AS A WEED DESTROYER

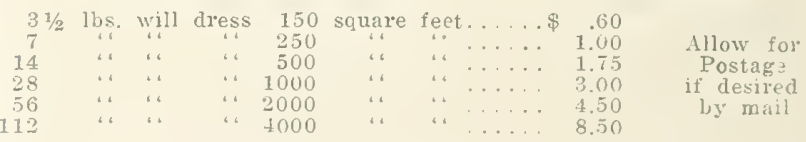

Send for complete Descriptive Circular

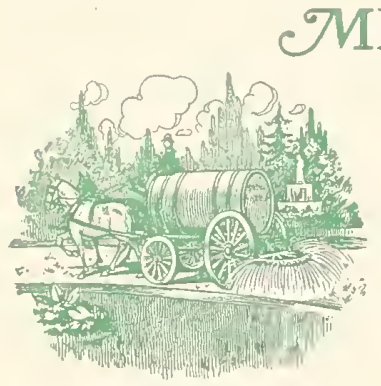

Liquid Weed Killer can ef fectually be distributed with a wagon.

\section{'MICHELLS' LIQUID WEED}

An effective combination of high-grade chemicals which, diluted in water at 1 to 40 , destroys the roots as well as the tops of all weeds and vegetation to which it is applied.

One gallon diluted is sufficient to cover 100 to 150 square yards; and one or two applications are sufficient for an entire season. Does not injure marble, cement or fencing. The best time for applying is just after a rain.

\section{KILLER,}

\section{PRICES OF "MICHELL'S"}

\section{WEED KILIER}

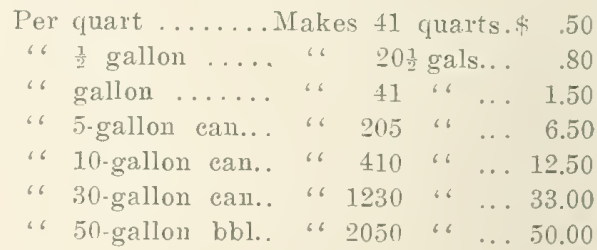

\section{Herbicide Weed Killer}

This preparation is a thoroughly proven Weed Exterminator. Will not stain wood or stone work. It dilutes readily in water and can be applied with a sprinkling ean or in a large area with a watering cart. For clay and sand tennis courts it is a perfect preparation. One part Herbicide dilutes to 40 parts of water, either hot or cold, elean or dirty. A gallou of Herbicide is capable of treating 120 square yards of surface.

$60 \mathrm{c}$. per quart, makes 10 gals. of treating liquid. $\frac{7}{2}$ gallon,
$\$ 1.00$, makes 20 gals. of treating liquid. 1 gallon, $\$ 1.75$, makes 41 gals. of treating liquid. 2 gallons, $\$ 3.25$, makes 82 gals. of treating liquid. 5 gallons, $\$ 7.00$, makes 205 gals. of treating liquid. 10 gals., $\$ 12.50$, makes 410 gals. of treating liquid. 25 gals., $\$ 27.50$, makes 1025 gals. of treating liquid. 50 gals., $\$ 47.50$, makes 2050 gals. of treating liquid.

\section{LIQUID WEED KILLERS CANNOT BE MAILED.}

\section{Erado Weed Gun}

Don't Continue Pulling Weeds. Destroy the Roots and the Top Cannot Re-appear

By the use of the apparatus "Herbicide" may be used safely and effectively on lawns for removing dandelions, burdoek, and other weeds that ruin a lawn.

This device is as handy as a cane, which it resembles; a reservoir, which holds about 2 quarts of liquid, is filled with Herbicide diluted and used for destroying weeds of all kinds in lawns without hurting the grass. It is 33 inches long and can be used very conveniently. The idea being to fill the reservoir and press the sharp point of the gun into the heart of the weed until the flat stay pieces touch the ground, when a quantity sufficient to kill the weed is discharged into the heart of the weed which is destroyed for all time. The use of this apparatus provides healthy pastime for the suburbanite, who otherwise does not care for garden work. Price, \$1.50. All brass. Pareel Post Weight, 2 lbs. 